UNIVERSIDADE DE SÃO PAULO

INSTITUTO DE BIOCIÊNCIAS

GIORDANO CIOCHETI

Uso de habitat e padrão de atividade de médios e grandes mamíferos e nicho trófico de Lobo-Guará (Chrysocyon brachyurus), Onça-Parda (Puma concolor) e Jaguatirica (Leopardus pardalis) numa paisagem agroflorestal, no estado de São Paulo.

São Paulo 


\section{GIORDANO CIOCHETI}

Uso de habitat e padrão de atividade de médios e grandes mamíferos e nicho trófico de Lobo-Guará (Chrysocyon brachyurus), Onça-Parda (Puma concolor) e Jaguatirica (Leopardus pardalis) numa paisagem agroflorestal, no estado de São Paulo.

Dissertação apresentada ao Instituto de Biociências da Universidade de São Paulo para obtenção de título de Mestre em Ecologia de Ecossistemas Aquáticos e Terrestres.

Orientadora: Prof. Dra. Vânia Regina Pivello 


\section{Ficha Catalográfica}

Ciocheti, Giordano

Uso de habitat e padrão de atividade de médios e grandes mamíferos e nicho trófico de Lobo-Guará (Chrysocyon brachyurus), Onça-Parda (Puma concolor) e Jaguatirica (Leopardus pardalis) numa paisagem agroflorestal, no estado de São Paulo. 78pp.

Dissertação (Mestrado) - Instituto de Biociências da Universidade de São Paulo. Departamento de Ecologia, 2008.

1.Armadilhas fotográficas; 2.Mamíferos de médio e grande porte; 3 . Padrão de atividade; 4. Uso de habitat; 5. Dieta; 6. Lobo-guará; 7. Felinos; 8. Índices de paisagem; 9. Fragmentação

Universidade de São Paulo, Instituto de Biociências. Departamento de Ecologia

\section{Comissão Julgadora}

Prof (a). Dr(a).

$\operatorname{Prof}(a) . \operatorname{Dr}(a)$.

Profa. Dra. Vânia Regina Pivello

Orientadora 


\section{Agradecimentos}

À Profa. Dra. Vânia Regina Pivello, minha orientadora, pela confiança e paciência depositadas em mim, pela amizade e pelos ensinamentos durante todo o período da dissertação.

Ao Prof. Jean Paul Metzger pelas conversas e bate papos nas horas de café e trabalho.

À Dra. Maria Carolina Lyra-Jorge eterna amiga de campo e laboratório. Carol sua companhia foi sempre muito agradável, tanto nas horas das piadas, quanto nas discussões acirradas sobre nossos trabalhos.

$\grave{A}$ todos as pessoas do LEPaC principalmente a Daniela Castro, Elizabeth Gorgone, Leandro Tambosi, Milton Cezar Ribeiro, Talita Zupo, Mariana Vidal, Cristina Banks, Alexandre Igari... Pessoal, eu sei que não é fácil me agüentar, valeu por todos os momentos em que tiveram paciência comigo, com minhas piadas nem sempre boas, meu gênio forte e brigão. Sem vocês acho que eu teria enlouquecido nesses últimos anos.

À Renata Alonso Miotto pela sempre agradável companhia, pelas parcerias científicas que nos rederam frutos no ano de 2007 e principalmente pela amizade acima de qualquer outra coisa. Re, você vai demorar para se livrar de mim em, temos muito o que fazer pelas onçinhas.

Ao Marco Antonio Marques de Souza, chefe e amigo, responsável pelo desenvolvimento das armadilhas fotográficas utilizadas neste trabalho e um grande exemplo a ser seguido. 
À Lilian Fernandes pelo apoio sentimental e emocional na fase final da dissertação.

Ao Daniel "amendoim" pela ajuda nas coletas de fezes e por passar 30 vezes por dia na frente das armadilhas fotográficas (hehehehe).

Obrigado a CNPQ e a Netropical Grassland Conservancy pelo auxílio financeiro que possibilitou a realização deste trabalho e pelo prêmio!!!!

À Neuza Pierina Bissoli Ciocheti, minha linda mãe, por toda a paciência, que só as mães tem, depositada em mim e em minha profissão (que não é fácil de compreender). Enfim, por tudo que ela já fez por mim em toda sua vida. Mãe TE AMO MUITO!!!!

Ao meu pai Ermetes Romualdo Ciocheti, que apesar de ter deixado nossas vidas cedo demais, me deu muito amor e todo o subsidio necessário para a solidificação de meu caráter e personalidade. Pai dedico este trabalho a você. 


\section{Índice:}

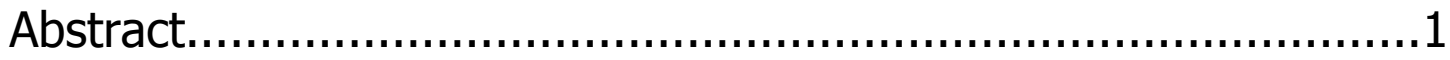

Resumo

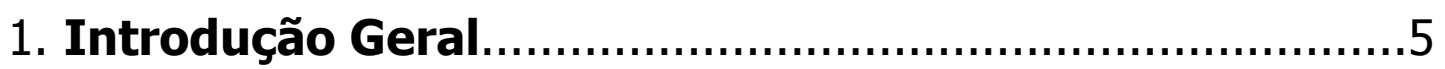

1.1. Situação geral, passada e atual do Cerrado e da Floresta Semidecídua na região de estudo..............................................

1.2. Os efeitos da fragmentação de habitats......................7

1.3. Estratégias para diminuir os efeitos da fragmentação de

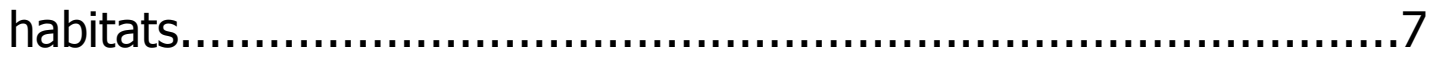

1.4. Perspectivas em Ecologia da Paisagem para a conservação de mamíferos de médio e grande porte...................8

2. Capítulo 1 - Freqüência e padrão de atividade de mamíferos de médio e grande porte em fragmentos com diferentes fitofisionomias e características estruturais na paisagem.................................11

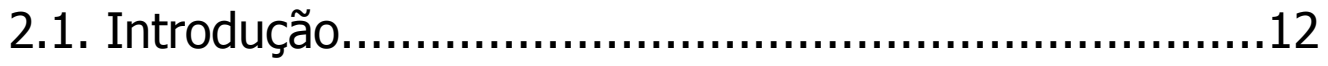

2.2. Materiais e métodos..............................................15

2.2.1. Área de estudo.............................................15

2.2.2 Armadilhamento Fotográfico...........................21

2.2.3. Riqueza de espécies.....................................22

2.2.4. Freqüências dos mamíferos de médio e grande porte por classes de uso e cobertura das terras..........................22

2.2.5. Freqüências dos mamíferos de médio e grande porte nos fragmentos amostrados.

2.2.6. Padrão de atividade. 


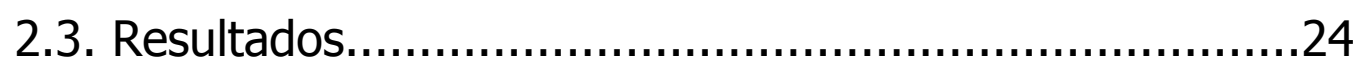

2.3.1. Espécies de mamíferos de médio e grande porte amostradas na região. 24

2.3.2. Freqüências dos mamíferos de médio e grande porte por classes de uso e cobertura das terras e padrões de atividade. 27

2.3.3. Relação entre a freqüência dos mamíferos amostrados com as características estruturais dos fragmentos.....35

2.4. Discussão. 38

2.5. Bibliografia 44

3. Capitulo 2 - Dieta e sobreposição de nicho de onça-parda (Puma concolor), jaguatirica (Leopardus pardalis) e lobo-guará (Chrysocyon brachyurus) numa paisagem fragmentada................50

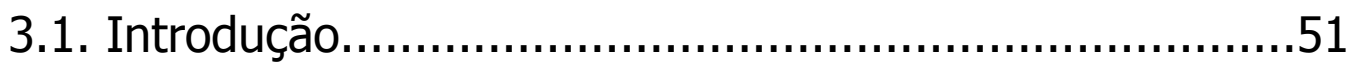

3.2. Materiais e métodos...............................................53

3.2.1. Área de estudo........................................................53

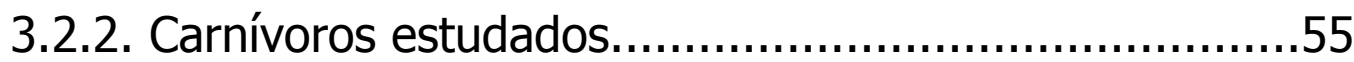

3.2.3. Coleta e triagem das fezes.......................................58

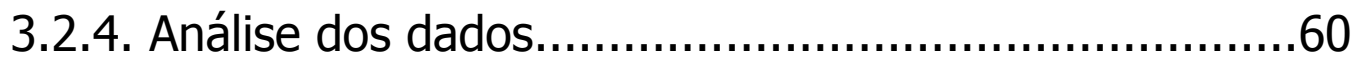

3.2.4.1. Descrição da dieta das espécies......................60

3.2.4.2. Comparação entre as dietas das espécies.......61

3.2.4.3. Abundância das fezes dos carnívoros estudados encontradas no campo em relação à quantidade de quilômetros percorridos. 
3.3.1. Dieta do lobo-guará (Chrysocyon brachyurus)..64

3.3.2. Dieta da jaguatirica (Leopardus pardalis).........65

3.3.3. Dieta da onça-parda (Puma concolor)...............66

3.3.4. Comparação entre as dietas dos três carnívoros

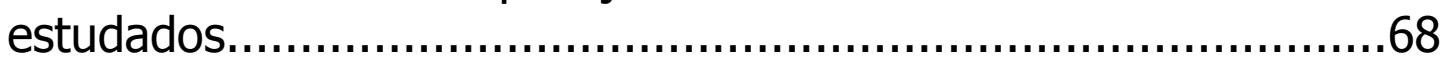

3.3.4.1. Amplitude de nicho............................68

3.3.4.2. Sobreposição de nicho.........................68

3.3.5. Densidade de fezes nas diferentes áreas.........68

3.4. Discussão..................................................................69

3.5. Bibliografia..........................................................

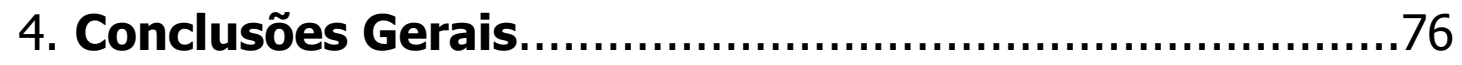




\section{Abstract}

The following study analyzed activity patterns and habitat use of large and medium size mammals as well as diet and trophic niche overlapping of feline and canid species in a fragmented area of the State of São Paulo. The landscape studied contains two fully protected conservation units with cerrado and semi-deciduous vegetation and also remnants of native semi-deciduous forest located in private properties. The general hypothesis of this study are: in more impacted environments, $i$, large and medium size mammal species tend to generalize their behavior regarding habitat use and activity patterns and $i i$, top food chain predators increase the competition for resources. The following aspects were studied through photographic traps and fecal sorting: a) frequency of different habitat use by large and medium size mammals; b) activity pattern of large and medium size mammals; c) diet and niche overlapping of three top food chain carnivores: Chrysocyon brachyurus, Puma concolor and Leopardus pardalis. Samples were withdrawn from seven fragments of native phytophysiognomies - cerrado sensu stricto, cerradão and semideciduous forest - and from areas of eucalyptus plantations. One hundred and sixty five photographs were obtained, where 17 species were identified. Two hundred and thirty three samples of feces were collected and identified, of which 93 of Chrysocyon brachyurus, 68 of Puma concolor, 38 of Leopardus pardalis, 30 of other small felines and 4 of Cerdocyon thous. The results show that, generally, large and medium size mammals use the entire area. However, more specialist mammals, such as the Sylvilagus brasiliensis, kept their preference for a more specific habitat. Spearman correlation tests demonstrated that those species which are more susceptible to anthropic alterations were more correlated with areas containing a higher connectivity and bigger size. The data also indicated that species are generalizing their behavior regarding the activity patterns: species that were active in some periods of the day are now remaining active in other periods as well. Among the carnivore species studied, Chrysocyon brachyurus was the specie with the most diversified diet, feeding on birds, reptiles, fruits, insects and mammals. Puma concolor and Leopardus pardalis had more restricted diets, where $90 \%$ of the items ingested belonged to other mammals. The trophic niche of $C$. brachyurus and L. pardalis species were 
strongly overlapped, indicating competition between them. The results obtained through photographic traps and diet analysis indicate that there might be a relation between more conserved areas (less isolated larger areas immersed in more permeable matrixes) and the frequency of mammals, the overlapping niche of top food chain carnivores ad the density of feces found.

Key-words: fragmentation, mammal, photographic traps, diet, competition, landscape ecology. 


\section{Resumo da dissertação}

O presente trabalho visou analisar padrões de atividade e uso de habitats por mamíferos de médio e grande porte, bem como dieta e sobreposição de nicho trófico de espécies de felinos e canídeos, numa região fragmentada do estado de São Paulo. Na paisagem estudada, existem duas unidades de conservação de proteção integral com vegetação de cerrado e floresta semidecídua, além de fragmentos de floresta nativa (semidecídua) em propriedades privadas. As hipóteses gerais do trabalho são: em ambientes mais impactados, $i$. as espécies de mamíferos de médio e grande porte tendem a generalizar seu comportamento de uso de habitat e padrão de atividade e ii. predadores de topo de cadeia alimentar aumentam a competição por recursos alimentares. Para explorá-las, foram estudados, por meio de armadilhas fotográficas e triagem de fezes, os seguintes aspectos: a) a freqüência do uso de diferentes habitats por mamíferos de médio e grande porte; b) o padrão de atividade de mamíferos de médio e grande porte; c) a dieta e a sobreposição de nicho de três carnívoros de topo de cadeia alimentar: lobo-guará (Chrysocyon brachyurus), onça-parda (Puma concolor) e jaguatirica (Leopardus pardalis). As coletas foram distribuídas em sete fragmentos, onde existem fitofisionomias nativas - cerrado sensu stricto, cerradão e floresta semidecídua - e também reflorestamento com espécies de eucaliptos. Foram obtidas 165 , fotografias, nas quais identificou-se 17 espécies. Foram coletadas e identificadas 233 amostras de fezes, sendo 93 de lobo-guará, 68 de onça-parda, 38 de jaguatirica, 30 de outros pequenos felinos e 4 de cachorro-do-mato. Os resultados mostraram que, de forma geral, os mamíferos de médio e grande porte utilizam a área como um todo; os mamíferos mais especialistas, como o tapiti (Sy/vilagus brasiliensis), mantiveram sua preferência por um habitat específico. Testes de correlação de Spearman mostraram que algumas espécies mais suscetíveis a alterações antrópicas mostraram-se correlacionadas a áreas com maior tamanho e grau de conectividade. Em relação aos padrões de atividade, os dados indicam que as espécies estão generalizando o seu comportamento: espécies que tinham atividade em alguns períodos do dia estão permanecendo ativas também em outros períodos. Quanto à dieta, o lobo-guará foi a 
espécie que utilizou mais itens entre os carnívoros estudados, alimentando-se de aves, répteis, frutos, mamíferos de diversos portes e insetos. A onça-parda e a jaguatirica apresentaram uma dieta mais restrita, sendo que os mamíferos representaram $90 \%$ dos itens consumidos. Houve uma alta sobreposição de nicho trófico entre lobo-guará e jaguatirica, indicando competição entre essas espécies. Os resultados, obtidos tanto por meio de armadilhamento fotográfico como por análise da dieta, indicam que pode existir uma relação entre áreas com maior grau de conservação (áreas maiores, menos isoladas estruturalmente e imersas em matrizes mais permeáveis) e a freqüência de mamíferos, a sobreposição de nicho dos carnívoros de topo e a densidade de fezes encontradas.

Palavras-chave: fragmentação, mamífero, armadilha fotográfica, dieta, competição, ecologia de paisagens. 


\section{Introdução Geral:}

\subsection{Situação geral, passada e atual do Cerrado e da Floresta Estacional Semidecídua na região de estudo}

O estado de São Paulo apresenta basicamente dois domínios vegetacionais: Floresta Atlântica e Cerrado (Savana). Segundo Victor (Victor 1975, apud Cavassan 2002), as fisionomias florestais do bioma Atlântico, tais como floresta ombrófila densa, floresta ombrófila mista, floresta estacional semidecídual, originalmente dominavam o Estado, ocupando mais de $80 \%$ de sua área (figura 1); as fisionomias de Cerrado, que variam de áreas abertas e campestres - como o cerrado campo limpo - a áreas fechadas e florestais - como o cerradão (figura 2) - ocupavam, 18,2\% do Estado.

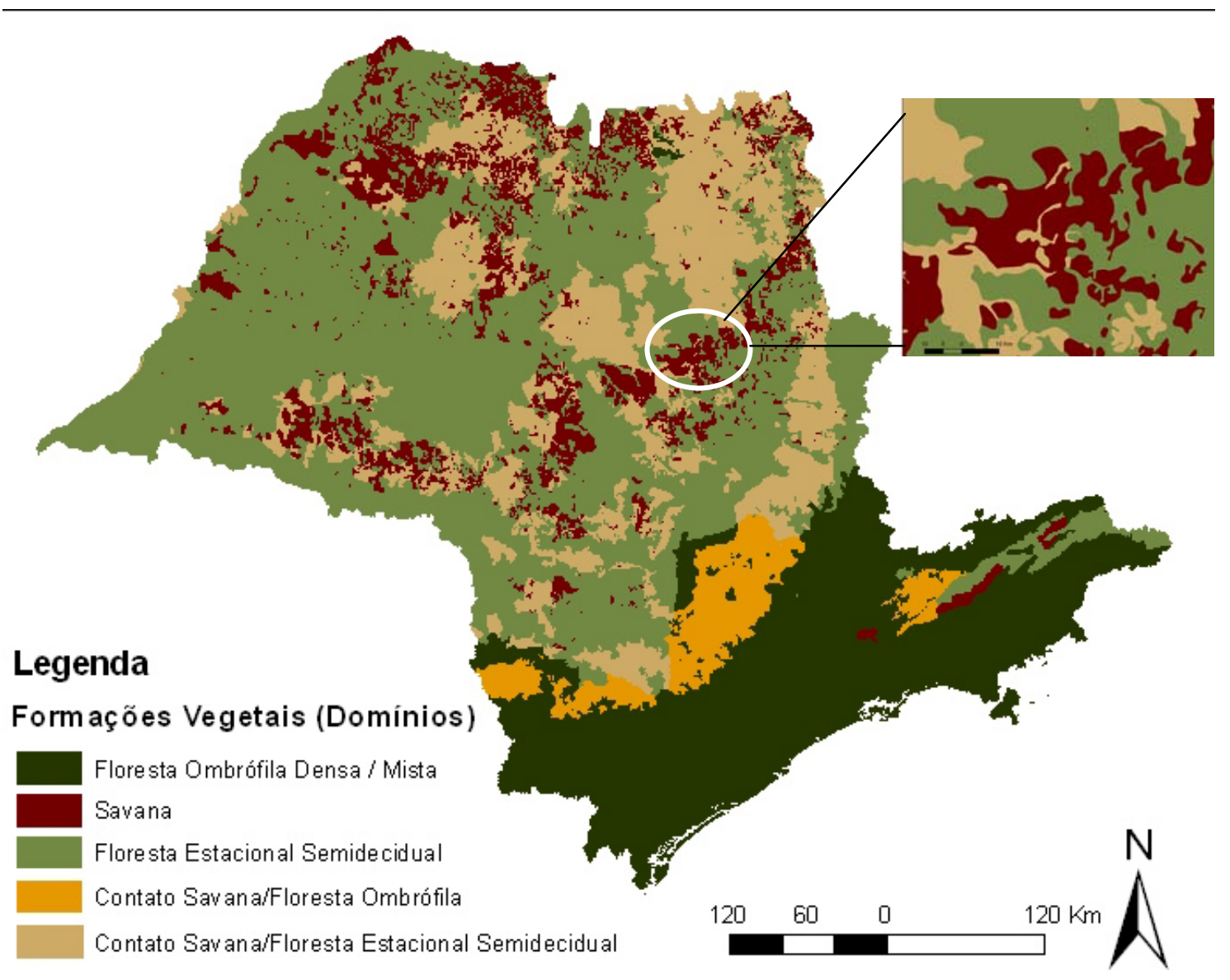

Figura 1. Domínio das formações vegetais que ocorrem no estado São Paul. Em destaque, a região de estudo (Fonte: BIOTA/FAPESP 2007). 


\section{Fisionomias Florestais}

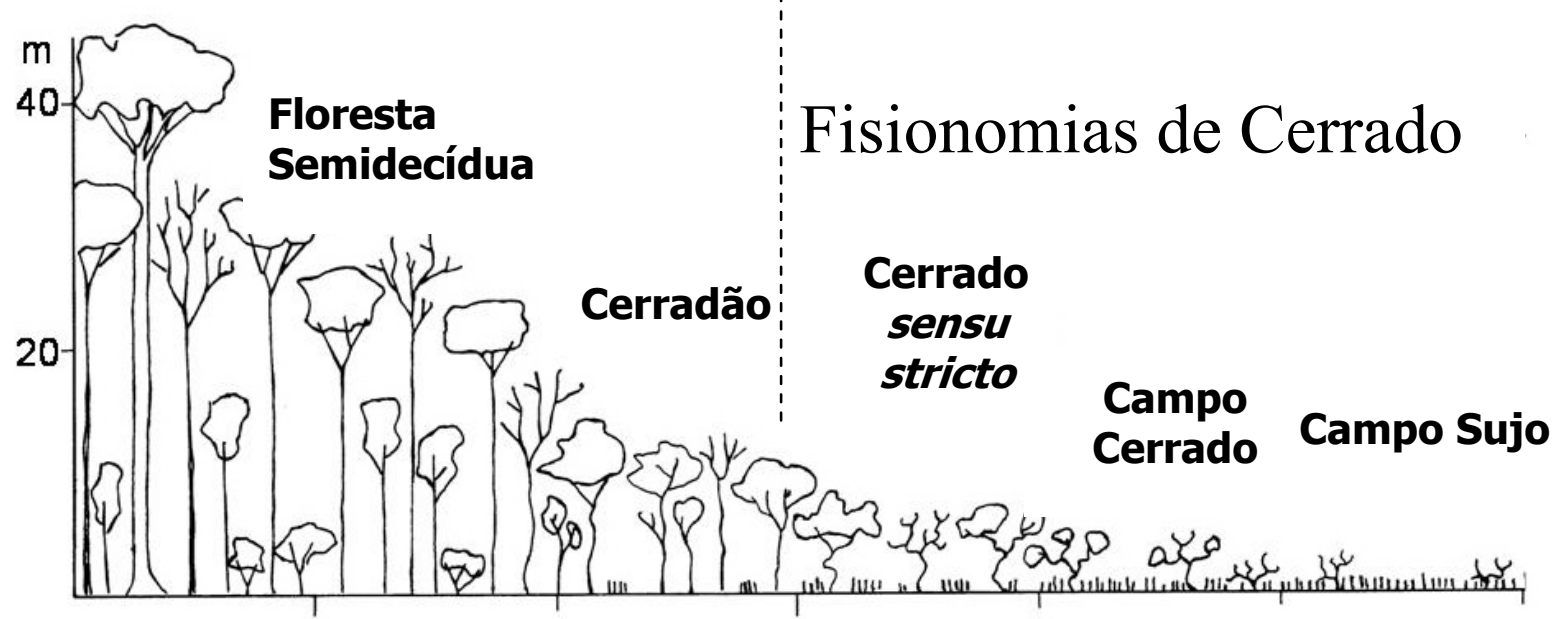

Figura 2. Gradiente de fisionomias florestais e campestres (adaptado de Coutinho, 1978).

Na região de estudo (figura 1) encontramos principalmente remanescentes de fisionomias de Cerrado e floresta semidecídua.

Atualmente, no domínio do Cerrado paulista, segundo os relatórios gerados pelo projeto BIOTA/FAPESP (2007), existem remanescentes em apenas 8,5\% da área original (tabela 1). Outra fisionomia presente outrora dominante, a floresta semidecídua, possui cobertura em 8,2\% da área original (tabela 1).

Tabela 1 Área original do domínio no estado de São Paulo e cobertura remanescente dos cerrados e das florestas estacionais semideciduais no estado de São Paulo (BIOTA/FAPESP 2007).

\begin{tabular}{ccc}
\hline & $\begin{array}{c}\text { FLORESTA } \\
\text { ESTACIONAL } \\
\text { SEMIDECÍDUA }\end{array}$ & CERRADO \\
ÁREA DO DOMÍNIO NO & 11.346 .499 ha & 2.474 .798 ha \\
ESTADO DE SÃO PAULO & & \\
$\begin{array}{c}\text { COBERTURA } \\
\text { REMANESCENTE }\end{array}$ & 927.663 ha $(8,2 \%)$ & 210.372 ha $(8,5 \%)$
\end{tabular}

O histórico da ocupação humana no interior do estado de São Paulo, com grandes áreas planas e solos produtivos, resultou no predomínio de monoculturas: cana-de-açúcar, pastagens e, mais recentemente, silvicultura com espécies de eucaliptos e Pinus. Esta ocupação originou uma paisagem muito alterada, composta por poucos fragmentos de vegetação nativa relativamente 
grandes ( $>1.000$ ha) e muitos fragmentos pequenos ( $<100$ ha), que representam, na maior parte dos casos, reservas legais (RL) e áreas de preservação permanente (APPs) das propriedades (principalmente topos de morros). Os três maiores remanescentes do domínio Cerrado existentes no estado de São Paulo encontram-se na região de estudo, sob a condição de Unidades de Conservação de Proteção Integral (UCsPI).

\subsection{Os efeitos gerais da fragmentação de habitats}

Essas fisionomias de Cerrado e floresta semidecídua, que anteriormente ocupavam grandes extensões e agora estão subdivididas em pequenos remanescentes, sofrem as conseqüências de um processo conhecido como fragmentação de habitats, cujos principais efeitos são: a) efeitos de borda, representados por alterações no microclima, como aumento nos níveis de insolação, temperatura, umidade e vento (Kapos 1989, Bierregaard 1992), fazendo com que plantas e animais pouco plásticos tenham sua população diminuída, ou até mesmo extinta, e que espécies plásticas aumentem de forma prejudicial sua densidade (Noss 1985); b) o isolamento de populações, o que consiste na separação de uma população em duas ou mais populações locais, diminuindo a diversidade genética e originando um maior número de cruzamentos consangüíneos, que podem levar ao declínio e extinção dessas populações (Wilcove \& May 1986, Shaffer 1990); c) perda e/ou redução de habitats, com provável isolamento dos fragmentos e diminuição dos recursos (Andrén 1994, Fahrig 2003, Schonewald-Cox \& Buecher 1992).

\subsection{Estratégias para diminuir os efeitos da fragmentação de habitats}

O antigo pensamento de que apenas aumentar a área das reservas existentes (ou criar reservas grandes, mas isoladas) seria ideal para manter a biodiversidade vem perdendo espaço para aquele que ressalta a importância de uma rede de fragmentos grandes e pequenos, que garantem uma maior diversidade de habitats favoráveis, para onde as espécies possam migrar e se estabelecer (Metzger 2006). 
A migração diminui a probabilidade de extinção das espécies (Burkey 1988), reduzindo os efeitos de competição, predação, consangüinidade, doenças e mudanças ambientais em um mesmo fragmento (Quinn \& Hastings 1987), além de permitir o estabelecimento de metapopulações (Hanski 2004). Entretanto, para que o fluxo de espécies na paisagem seja possível, é necessário que haja conectividade funcional entre os fragmentos remanescentes (Godwin \& Fahrig 2002).

Existem diversas estratégias para se promover o aumento da conectividade em paisagens fragmentadas. A criação de corredores florestais (habitat linear, envolto por matriz, que conecta dois ou mais blocos de habitats) (Beier \& Noss 1998) é uma das saídas para o manejo dessas áreas. Muitos autores concordam que a interligação de áreas aumenta a viabilidade populacional (Meffe \& Carroll 1997). Por outro lado, outros alertam para riscos que os corredores possam trazer, tais como dispersão de doenças, distúrbios e invasão de espécies exóticas (Simberloff 1992). A funcionalidade dos corredores é outro ponto crucial, pois a maioria dos corredores possui pouca largura, o que acaba por expor toda a sua área a efeitos de borda, inviabilizando sua utilização por espécies de interior (Haddad et al. 2003).

Outro tipo de ação para o incremento de conectividade é o manejo da matriz, com estratégias que visem torná-la mais permeável às espécies (Castellón \& Sieving 2006), como por exemplo, a criação de trampolins ecológicos (pequenos fragmentos esparsos na paisagem) e agroflorestas, que, de um modo geral, facilitam o fluxo de espécies entre os fragmentos.

\subsection{Perspectivas em Ecologia da Paisagem para a conservação de mamíferos de médio e grande porte}

Para se manejar uma área de forma coesa e funcional, implementando estratégias que realmente protejam a maior biodiversidade possível, deve-se conhecer as relações entre as espécies ou grupos funcionais, bem como as características da paisagem onde se insere a área de estudo (Shaffer 1990, Wiens 1995). Além disso, deve-se definir a paisagem e suas características pela "visão" das próprias espécies (Metzger 2006), isto é, delimitar espacial e funcionalmente as paisagens e suas variáveis, com base na biologia das espécies ou grupos biológicos estudados. 
O conceito de espécie guarda-chuva, isto é, espécie que possui necessidades ecológicas maiores do que outras, quando aplicado, pode garantir a proteção de espécies menos exigentes, sendo essencial em ações rápidas de manejo visando à manutenção da biodiversidade (Lambeck 1997). A dificuldade está em se determinar quais espécies/grupos podem ser guarda-chuvas e para quais características possuem maiores requerimentos do que outras. Diversos estudos analisam os efeitos da composição (tipos de classes de uso e cobertura das terras) e da configuração da paisagem (arranjo espacial das unidades que compõem a paisagem) sobre as espécies presentes nessas áreas (Laurence 1991, Gascon et al. 1999, Metzger 2000). Relacionam riqueza e abundância das espécies aos tipos de matrizes, distância entre remanescentes e tamanho de fragmentos. No entanto, os que utilizam riqueza de espécies são bastante criticados, pois este não é considerado um valor auto-explicativo (Fleishman et al. 2006); o conceito de riqueza de espécies não separa as espécies sensíveis às alterações antrópicas daquelas não sensíveis. Assim, em duas áreas, uma com riqueza igual a 25 e outra com riqueza igual a 21 espécies, por exemplo, não se pode garantir que as 25 espécies da primeira área sejam mais representativas para a conservação da biodiversidade do que as 21 encontradas na outra área, pois a área mais rica pode ter uma alta proporção de espécies oportunistas ou generalistas. Desta forma, deve-se preferir utilizar, quando possível, variáveis qualitativas, como densidade e freqüência. Espécies de pequeno porte - por exemplo: aves, roedores e lagartos - são de fácil captura e recaptura e assim, pode-se obter estimativas de densidade e utilizá-las nos estudos. Espécies de maior porte - como os médios e grandes mamíferos - são de difícil captura e, desta forma, deve-se utilizar a freqüência da espécie em relação ao grupo estudado para as análises. A freqüência é calculada com base na probabilidade do individuo de uma determinada espécie passar, ao acaso, em uma determinada área (por exemplo, em um canteiro de pegadas ou em frente a uma armadilha fotográfica). Utilizando a freqüência e/ou densidade das espécies-alvo, pode-se verificar a influência das variáveis ambientais de forma isolada para cada espécie e, assim, entender as relações entre a paisagem e as espécies presentes.

Este trabalho teve como objetivo geral analisar o uso de habitats, o padrão de atividade de médios e grandes mamíferos e a dieta de três espécies carnívoras, numa paisagem altamente fragmentada mas onde se encontram os maiores remanescentes de cerrado do estado de São 
Paulo. Visou contribuir para a conservação desse grupo faunístico, que está sob forte efeito da fragmentação e perda de habitats, oriundas da ocupação desenfreada das terras paulistas. Os resultados também podem ser utilizados para subsidiar estratégias de manejo que aumentem a conectividade funcional da paisagem no estado de São Paulo, a serem recomendadas nos planos de manejo das unidades de conservação presentes na área, em desenvolvimento pela Fundação Florestal (FF).

Esta dissertação está organizada em dois capítulos. O primeiro teve como objetivos: i) avaliar a freqüência de mamíferos de médio e grande porte em fisionomias de Cerrado, Floresta Semidecídua e monocultura de eucaliptos, ii) relacionar a freqüência das espécies de mamíferos de médio e grande porte nos fragmentos estudados em relação às características estruturais destes fragmentos, iii) avaliar o padrão de atividade de mamíferos de médio e grande porte na área de estudo. Os objetivos do segundo capítulo foram: i) avaliar a dieta de onça-parda (Puma concolor), jaguatirica (Leopardus pardalis) e lobo-guará (Chrysocyon brachyurus) na área de estudo, ii) quantificar a sobreposição de nicho trófico entre essas espécies, por meio da análise de suas dietas. 
2.

FREQÜÊNCIA E PADRÃO DE ATIVIDADE DE MAMÍFEROS DE MÉDIO E GRANDE PORTE EM FRAGMENTOS COM DIFERENTES FITOFISIONOMIAS E CARACTERÍSTICAS ESTRUTURAIS NA PAISAGEM 


\subsection{Introdução:}

O bioma Cerrado faz fronteira com quatro outros biomas brasileiros: Pantanal, Floresta Amazônica, Floresta Atlântica e Caatinga (Eiten 1979). Toda essa diversidade de contatos e a própria diversidade de fisionomias do Cerrado garantem uma enorme biodiversidade de fauna e flora, sendo o Cerrado considerado um dos "hotspots" mundiais (CI 2005). Segundo Mantovani (1998), 65\% de sua vegetação nativa já foi destruída. Apenas 1,6\% da área total do bioma, em todo o Brasil, está em unidades de conservação, que não são suficientes para a manutenção de sua biodiversidade, principalmente pelo alto grau de isolamento em que se encontram essas áreas protegidas. No estado de São Paulo, a situação chega a ser pior: apenas $0,5 \%$ do domínio do Cerrado no estado estão em unidades de conservação de proteção integral. A floresta semidecídua encontra-se em situação semelhante, com 0,6\% de seus remanescentes em UCsPI (tabela 1).

Tabela 1. Área original do domínio no estado de São Paulo e cobertura remanescente dos cerrados e da floresta estacional semidecídua no estado de São Paulo e nível de proteção integral para fitofisionomias presentes no estado de São Paulo (adaptado de BIOTA/FAPESP 2007)

\begin{tabular}{cccccc}
\hline FITOFISIONOMIA & $\begin{array}{c}\text { Domínio- original } \\
\text { no Estado (ha) }\end{array}$ & $\begin{array}{c}\text { Cobertura } \\
\text { atual (ha) }\end{array}$ & $\begin{array}{c}\text { UCs } \\
\text { integral } \\
\text { (ha) }\end{array}$ & $\begin{array}{c}\text { \% da } \\
\text { cobertura } \\
\text { em UCs } \\
\text { integral }\end{array}$ & $\begin{array}{c}\text { \%om do } \\
\text { Domínio } \\
\text { em UCs } \\
\text { integral }\end{array}$ \\
$\begin{array}{c}\text { Floresta Ombrófila } \\
\text { Densa }\end{array}$ & $4.786,394$ & $2.012,143$ & 627,542 & $31 \%$ & $13 \%$ \\
$\begin{array}{c}\text { Floresta Ombrófila } \\
\text { Mista }\end{array}$ & 550,473 & 146,661 & 7,795 & $5 \%$ & $1,4 \%$ \\
$\begin{array}{c}\text { Floresta Estacional } \\
\text { Semidecídua }\end{array}$ & $11.346,499$ & 927.663 & 68,842 & $8 \%$ & $0,6 \%$ \\
$\begin{array}{c}\text { Cerrado sensu lato } \\
\text { Total }\end{array}$ & $2.474,798$ & 210.372 & 13,624 & $6 \%$ & $0,5 \%$ \\
\hline
\end{tabular}

Há alguns estudos que mostram o uso de habitats por mamíferos de médio e grande porte em diferentes fitofisionomias (Alho et al. 1986, Fonseca \& Redford 1984, Jácomo 1999), no entanto, em áreas antropizadas, os poucos estudos existentes são recentes, o que demonstra a maior importância dada a esses ambientes alterados apenas no momento atual (Daily et al. 2003, Faria et al. 2006 e Lyra-Jorge 2007). 
Considerando-se o nicho de uma espécie como um hiper-volume, pode-se dizer que as variáveis ambientais que constituem esse hiper-volume regulam a sua distribuição (Hutchinson 1959). As espécies podem ser mais ou menos sensíveis a essas variáveis e essa sensibilidade está relacionada às características próprias das espécies. Mamíferos de grande e médio porte geralmente não têm muita sensibilidade a variáveis amplas, como temperatura e altitude - muitas das espécies possuem distribuições continentais, aceitando uma grande variância dentro das variáveis ambientais (Anderson et al. 2003).

A fragmentação dos habitats naturais gera perturbações que alteram as faixas de valores destas características ambientais mais amplas (temperatura, umidade etc), mas geralmente são mudanças nas condições locais, refletidas por efeitos de borda (Noss 1985), o que não implica na alteração da distribuição da espécie. Ao que parece, em ambientes de médio a alto grau de fragmentação, a distribuição das espécies é determinada em maior grau pelas alterações na conformação da paisagem. Esta idéia se reforça com as teorias dos limiares de fragmentação: i) quando uma paisagem possui menos de $30 \%$ de remanescentes o isolamento entre esses faz com que a estrutura do mosaico formado pelos fragmentos seja muito importante na persistência das populações e/ou metapopulações (Andrén 1994); ii) quando a distância do fragmento focal aos fragmentos mais próximos, dividida pelo número de fragmentos circundantes, for maior que a capacidade de deslocamento da espécie focal na matriz da paisagem, o arranjo espacial também se torna fundamental para a manutenção da espécie focal na região (Fahrig 1998). Portanto, a distribuição e a sobrevivência das espécies em longo prazo dependem de características de composição e conformação dos fragmentos na paisagem.

Dentre as características das paisagens fragmentadas, aquelas que merecem destaque quanto à sua importância na manutenção da biodiversidade são: i) tipos de fitofisionomias naturais remanescentes; ii) tipos de usos das terras pelo homem; iii) tamanho máximo, médio e mínimo de fragmentos naturais remanescentes (= habitat); iv) número de fragmentos naturais remanescentes; v) contraste entre a matriz e o habitat (resultando na permeabilidade da matriz); vi) densidade de estruturas que gerem conectividade (e.x. corredores, trampolins ecológicos); vii) influência de efeitos de borda antropogênicos causados nos diferentes fragmentos remanescentes. Direcionar os estudos de freqüência de uso de habitat para essas características da paisagem 
pode determinar quais variáveis podem influenciar na distribuição das espécies e em que escala isso acontece.

Desta forma, a indagação sobre o comportamento das espécies carnívoras numa paisagem fragmentada, como a área de estudo, objetivou: i) avaliar a dependência de cada espécie, através da quantificação de sua freqüência, às diferentes fisionomias de vegetação presentes na área; ii) avaliar a influência das características espaciais dos fragmentos sobre a freqüência das espécies; iii) avaliar o padrão de atividade de mamíferos de médio e grande porte na área de estudo; iv) identificar, nessa paisagem, fragmentos mais e menos utilizados pelas espécies, reconhecendo áreas-fonte de indivíduos (Hanski 2004) e áreas-chave para a conectividade da paisagem- (Paese 2002). 


\subsection{Materiais e Métodos:}

\subsection{1 Área de Estudo:}

A área de estudo ocupa aproximadamente 70.000 ha e localiza-se entre as coordenadas $21^{\circ} 30^{\prime}-21^{\circ} 45^{\prime} \mathrm{S}$ e $47^{\circ} 20^{\prime}-47^{\circ} 55^{\prime} \mathrm{W}$.

O clima é tropical savânico, ou do tipo II, conforme a classificação de Walter (1986). A temperatura nos meses de inverno (estação seca) varia de 15 a $31^{\circ} \mathrm{C} \mathrm{e}$, nos meses mais quentes (estação úmida), de 20 a $36^{\circ} \mathrm{C}$ (Nimer 1977). A pluviosidade anual é geralmente superior a 1.400 mm, com um período de precipitação mais intenso, de outubro a março, e índices pluviométricos mensais superiores a $100 \mathrm{~mm}$ (Pires 1995).

O relevo é plano, com pequenas ondulações e depressões, e altitudes variando de 520 a 1.000 m (Shida 2005). Os solos mais representativos são os arenosos, pertencentes às subordens Neossolo Quartzarênico e Latossolo Vermelho-Amarelo (Ruggiero et al. 2002).

Nessa região, encontramos os maiores remanescentes de vegetação natural protegidos em duas unidades de conservação, e pequenos fragmentos de fisionomias de Cerrado e floresta semidecídua (< 100 ha), localizados em propriedades particulares. As fitofisionomias presentes na região são: cerradão, cerrado sensu stricto, campo limpo, campo sujo, floresta estacional semidecídua e floresta ribeirinha.

As unidades de conservação encontradas na área de estudo são: Parque Estadual de Vassununga (PEV), Estação Ecológica de Jataí (EEJ) e Estação Experimental de Luiz Antônio (EELA), que se encontram nos municípios de Santa Rita do Passa Quatro e Luiz Antônio (figura 1) e são gerenciados pela Fundação Florestal de São Paulo (Kronka et al. 1993). 


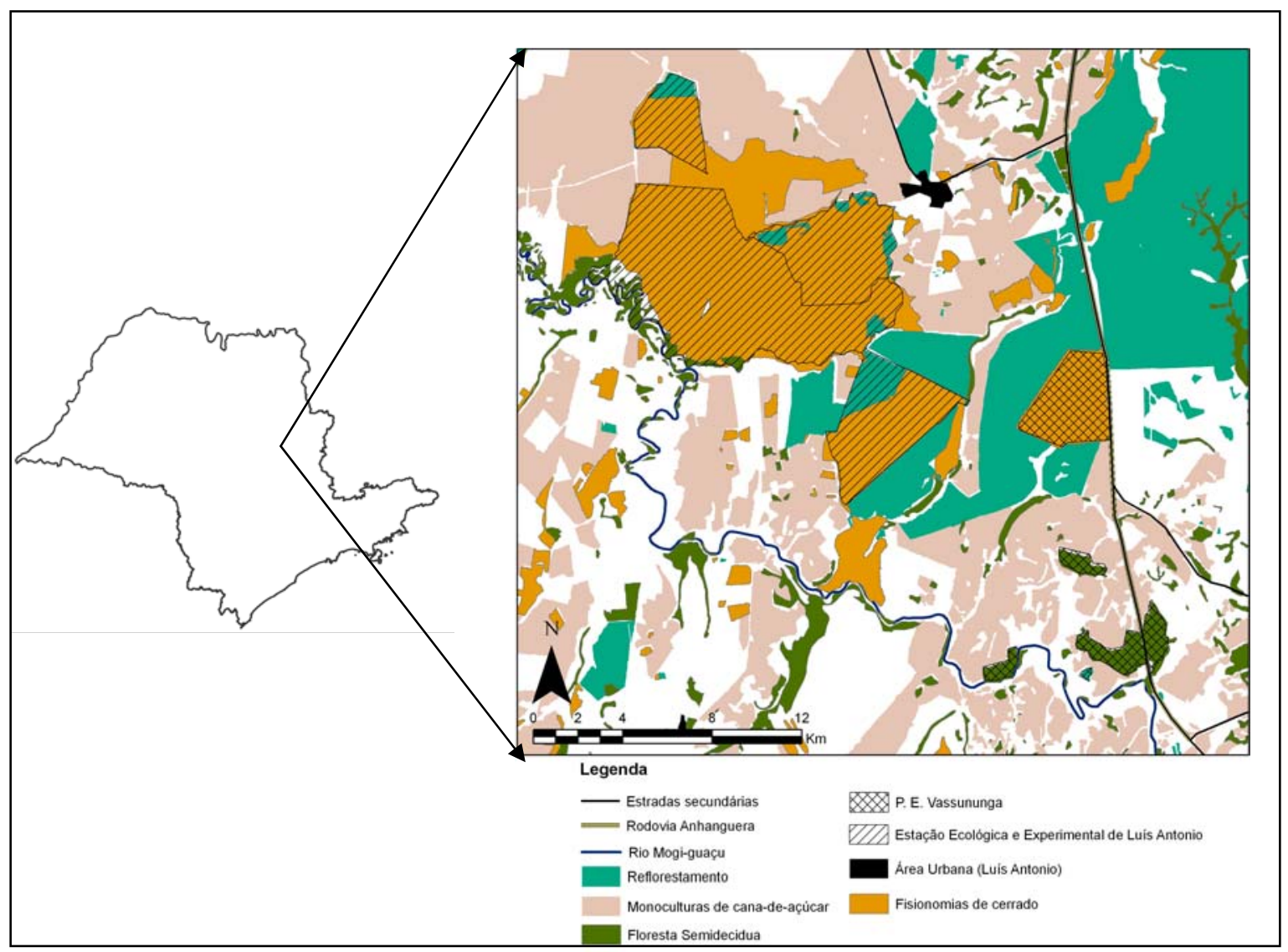

Figura 1. Área de estudo (organização Giordano Ciocheti).

A EEJ e a EELA são compostas de três áreas disjuntas: a) Gleba A, envolve parte da EEJ e é contínua à área da EELA, onde atualmente há plantações de eucaliptos e pinheiros, algumas delas cortadas e/ou abandonadas, além de remanescentes secundários de fisionomias de cerrado (sensu stricto e cerradão) e de floresta semidecídua. Possui aproximadamente 10.800 ha; b) Gleba Oitocentos Alqueires $(\mathrm{OA})$, separada da gleba anterior por uma área em regeneração, sem manejo, e uma estrada com fluxo razoável de veículos, que dá acesso principalmente à cidade de Luiz Antônio e à balsa do rio Mogi-Guaçu. A vegetação predominante é de cerradão e possui aproximadamente 1.600 ha; c) Gleba B, separada da gleba A por uma estrada com trânsito de caminhões e automóveis (estrada da Votorantin); a vegetação predominante é de cerradão e a área é de aproximadamente 650 ha.

O PEV é composto por seis glebas: a) Capetinga Oeste (CO): Com vegetação de floresta semidecídua, possui cerca de 340 ha e é cercada por monocultura de cana-de-açúcar e pela rodovia Anhanguera. A gleba é aberta à visitação, pois nela existe o maior exemplar de Jequitibárosa (Cariniana legalis) do estado de São Paulo; b) Capetinga Leste (CL) Com vegetação 
predominante de floresta semidecídua, possui aproximadamente 91 ha e é envolta por monocultura de cana-de-açúcar e pela rodovia Anhanguera; c) Praxedes (PRA) Vegetação de floresta semidecídua, com cerca de 160 ha de área. É cercada por monocultura de cana-deaçúcar; d) Maravilha (MAR) Também com vegetação de floresta semidecídua, possui cerca de 130 ha e é envolta por cana-de-açúcar e pelo rio Mogi-Guaçu; e) Capão da Várzea (CV) Com vegetação de floresta semidecídua e 14 ha de área, é circundada por monocultura de cana-deaçúcar; f) Pé-de-Gigante (PG) Possui fisionomias de Cerrado (cerrado sensu stricto, cerradão e cerrado campo sujo) e floresta semidecídua. Sua área é de aproximadamente 1.250 ha. Faz divisa a oeste, norte e sudoeste com monoculturas de eucaliptos, a sudeste com monocultura de canade-açúcar e a leste com a rodovia Anhanguera.

Segundo Tambosi (2008), o uso das terras no entorno (10 km de raio a partir das bordas das glebas) das unidades de conservação acima citadas, é constituído por atividades agropecuárias, principalmente monoculturas de cana-de-açúcar. Essas duas atividades dominam a paisagem ( $46,1 \%$ do total da área) e exercem influência sobre as Ucs acima citadas, mas envolvem inteiramente apenas as cinco glebas de floresta semidecídua pertencentes ao PEV (CL, CO, CV, PRA e MAR). As atividades agroflorestais (principalmente monoculturas de eucaliptos, 29,3 \% da área) fazem borda com as glebas PG e OA e estão inseridas dentro da EEJ e EELA, onde há também monoculturas de Pinus spp.. Segundo Shida (2005), em 1962 só havia atividades agroflorestais na área da futura EEJ e EELA e numa região a leste da rodovia Anhanguera. Enquanto que, dentro da EEJ e EELA, a área utilizada para essas atividades foi diminuindo, ela aumentou nas áreas externas às Ucs, que eram anteriormente cobertas por fisionomias de Cerrado, principalmente na região do $\mathrm{OA}$ e do $\mathrm{PG}$, determinando o formato atual dos fragmentos e isolando estruturalmente as duas áreas já citadas (OA e PG) e a EEJ, que eram interligadas até meados dos anos 70. Os fragmentos de Floresta Semidecídua pertencentes ao PEV já eram isolados por atividades agropecuárias desde antes de 1962 (figura 2). 


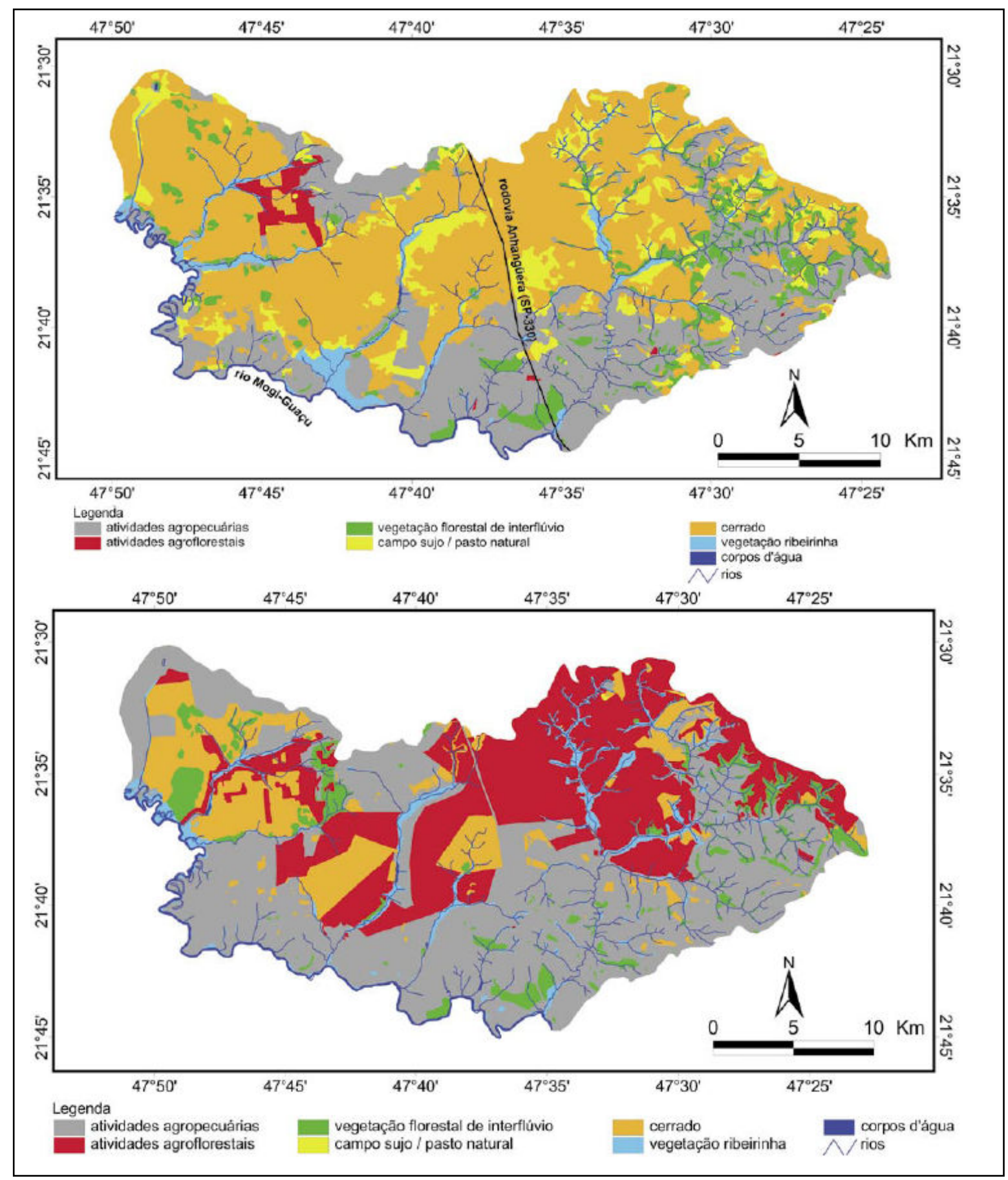

Figura 2. Uso e cobertura das terras na área de estudo em 1963 (a) e 2001 (b) (Shida 2005).

A avaliação da freqüência do uso de habitat pelos mamíferos e dos seus padrões de atividade foi feita em dois fragmentos de floresta semidecídua (CO e PRA), um de cerradão (OA), um com cerrado sensu stricto e cerradão (Gleba A), dois de cerrado sensu stricto (Tamanduá e PG) e dois conjuntos de talhões de plantios com eucaliptos (tabela 2). 
Tabela 2. Denominação e características gerais das áreas amostradas (as áreas de reflorestamento possuem plantio de espécies de Eucaliptos).

\begin{tabular}{|c|c|c|c|c|}
\hline Área & $\begin{array}{l}\text { Tamanho } \\
\text { (ha) }\end{array}$ & Denominação & Localização & $\begin{array}{l}\text { Uso e Cobertura das terras } \\
\text { / tipos de matriz }\end{array}$ \\
\hline 1 & 10.800 ha & $\begin{array}{l}\text { Gleba A EEJ + } \\
\text { EELA }\end{array}$ & $\begin{array}{c}\text { Estação } \\
\text { Ecológica de } \\
\text { Jataí }\end{array}$ & $\begin{array}{c}\text { Cerrado sensu stricto e } \\
\text { cerradão / Cana-de-açúcar, } \\
\text { pastagem e reflorestamento }\end{array}$ \\
\hline 2 & 523 ha & Eucalipto 1 & $\begin{array}{l}\text { Fazenda } \\
\text { Limoeiro }\end{array}$ & Reflorestamento \\
\hline 3 & 309 ha & Eucalipto 2 & $\begin{array}{l}\text { Fazenda } \\
\text { Limoeiro }\end{array}$ & Reflorestamento \\
\hline 4 & $1.527 \mathrm{ha}$ & $\begin{array}{l}\text { Oitocentos } \\
\text { Alqueires }\end{array}$ & $\begin{array}{c}\text { Estação } \\
\text { Ecológica de } \\
\text { Jataí }\end{array}$ & $\begin{array}{c}\text { Cerradão / Cana-de-açúcar e } \\
\text { Reflorestamento }\end{array}$ \\
\hline 5 & 131 ha & Tamanduá & $\begin{array}{l}\text { Fazenda } \\
\text { Limoeiro }\end{array}$ & $\begin{array}{l}\text { Cerrado sensu stricto / } \\
\text { Cana-de-açúcar }\end{array}$ \\
\hline 6 & $1.250 \mathrm{ha}$ & Pé-de-Gigante & $\begin{array}{c}\text { Parque } \\
\text { Estadual de } \\
\text { Vassununga }\end{array}$ & $\begin{array}{c}\text { Cerrado sensu stricto / } \\
\text { Reflorestamento e Cana-de- } \\
\text { açúcar }\end{array}$ \\
\hline 7 & 175 ha & Praxedes & $\begin{array}{c}\text { Parque } \\
\text { Estadual de } \\
\text { Vassununga }\end{array}$ & $\begin{array}{l}\text { Floresta Semidecídua / } \\
\text { Cana-de-açúcar }\end{array}$ \\
\hline 8 & 325 ha & Capetinga Oeste & $\begin{array}{c}\text { Parque } \\
\text { Estadual de } \\
\text { Vassununga }\end{array}$ & $\begin{array}{l}\text { Floresta Semidecídua / } \\
\text { Cana-de-açúcar }\end{array}$ \\
\hline
\end{tabular}

Um mapa de uso e cobertura das terras (1:15.000) foi elaborado por Tambosi (2008) (Figura 3), sobre o qual foram calculadas algumas métricas de paisagem, usando-se o programa FRAGSTATS (MacGarigal et al. 2002). As métricas inicialmente calculadas foram: i) CanP: perímetro com plantio de cana-de-açúcar, adjacente ao fragmento focal; ii) CanA: área da plantação de cana-de-açúcar adjacente ao fragmento focal; iii) HerP: perímetro de vegetação herbácea adjacente ao fragmento focal; iv) HerA: área de vegetação herbácea adjacente ao fragmento focal; v) ProP: perímetro de instalações rurais adjacentes ao fragmento focal; vi) ProA: área de instalações rurais adjacentes ao fragmento focal; vii) SolP: perímetro de solo exposto adjacente ao fragmento focal; viii) SolA: área de solo exposto adjacente ao fragmento adjacente; ix) EucA: área de plantio de eucalipto adjacente ao fragmento focal; $x$ ) EucP: perímetro do plantio de eucalipto adjacente ao fragmento focal; xi) PasA: área de pasto adjacente ao fragmento focal; xii) ArbP: perímetro de vegetação arbórea adjacente ao fragmento focal; xiii) ArbA: área de vegetação arbórea adjacente ao fragmento focal; xiv) EstP: perímetro de estradas adjacente ao 
fragmento focal; xv) Area: área do fragmento focal; xvi) Peri: perímetro do fragmento focal; xvii) Para: relação perímetro / área do fragmento focal; xviii) Shape: índice de forma do fragmento focal (valores próximos a 1 indicam uma forma circular, valor maiores indicam formas mais alongadas e/ou dendríticas; xiv) Prox: índice de proximidade, que é calculado com base nos valores das distâncias (dentro de um raio de busca) dos fragmentos, de mesma fitofisionomia, ao redor do remanescente -alvo e suas áreas totais, xv) Enn: distância do fragmento focal ao vizinho mais próximo, em linha reta.

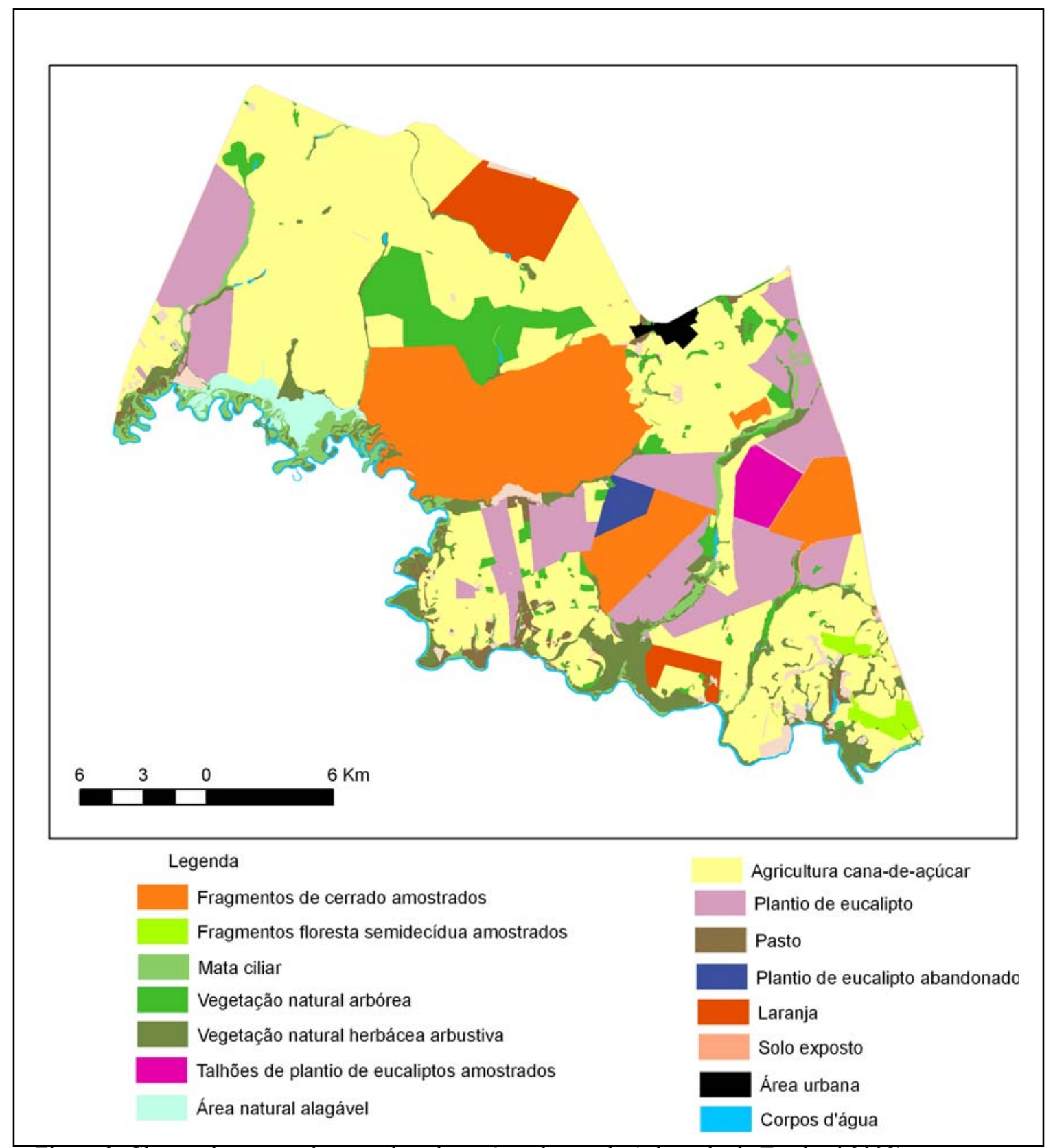

Figura 3. Classes de uso e cobertura do solo na área de estudo (adaptado de Tambosi 2008). 


\subsubsection{Armadilhamento Fotográfico}

A freqüência e o padrão de atividade dos mamíferos de médio e grande porte foram avaliados de forma não invasiva (Karanth 1995, Silveira et al. 2003), por meio de armadilhas fotográficas, da marca Trapa Câmera (www.trapacamera.com.br) que funcionam por meio de um sensor de movimento e calor, assim que um indivíduo é detectado o sensor percebe o movimento e aciona a máquina fotográfica que dispara registrando a sua passagem. Esse equipamento é simples de se utilizar, mas alguns cuidados foram tomados na instalação:

1-Foram evitadas áreas expostas ao sol, uma vez que altas temperaturas, geradas pela exposição, fazem com que a câmera dispare a esmo;

2-Não foram colocadas câmeras voltadas para onde o sol nasce ou se põe, pois a incidência de luz direta também pode fazer a câmera disparar;

3-Foram evitadas áreas com alta umidade, pois se muita umidade penetrar na parte eletrônica da armadilha, ela fatalmente deixará de funcionar em pouco tempo;

4-As áreas ao redor das armadilhas foram limpas. Como as armadilhas utilizam sensores de calor e movimento, as áreas próximas a ela devem ser limpas, para evitar falsos disparos (plantas aquecidas pelo sol e movimentadas pelo vento podem parecer uma animal homeotérmico para os sensores) e para não existir nada entre o sensor e o local de passagem dos indivíduos, evitando assim falhas na detecção;

4-As armadilhas foram fixadas em anteparos (árvore, madeira) para que não oscilassem e não disparassem com o vento.

Os mamíferos utilizam muito as estradas de terra, trilhas e carreadores para locomoção. Desta forma, as câmeras eram colocadas nesses locais, com o objetivo de obter o maior número possível de fotografias.

O critério de distribuição das câmeras levou em conta a área total das diferentes classes de vegetação amostradas (cerradão, cerrado sensu stricto, floresta semidecídua e monocultura de eucalipto). Desta forma, o número de câmeras foi diferente para cada classe - nove câmeras no 
cerrado sensu stricto, sete no cerradão, quatro na monocultura de eucalipto e três na floresta semidecídua.

\subsubsection{Riqueza de espécies:}

Por meio das armadilhas fotográficas e utilizando um procedimento de rarefação (Santos 2003, Barlow et al. 2007), uma curva de acumulação de espécies, utilizando o estimador Mao Tao (Colwell 2004) com 5.000 aleatorizações foi utilizada para garantir a eficiência do tempo de coleta. O valore de riqueza esperada de espécies foi obtido por meio do estimador não-paramétrico Bootstrap (Smith \& Van Belle 1984).

\subsubsection{Freqüências dos mamíferos de médio e grande porte por classes de uso e cobertura das terras:}

A freqüência de cada uma das espécies de mamíferos nas diferentes classes de uso e cobertura das terras foi calculada pela seguinte fórmula, permitindo a comparação entre as diferentes áreas:

$$
F C i j=n i j / N j \text {, }
$$

onde, FCij é a freqüência da espécie i na classe j, nij é o número de fotografias da espécie i na classe j e $\mathrm{Nj}$ é o número total de fotografias de todas as espécies amostradas na classe j.

Um teste de Kurskal-Wallis (Conover 1980) foi utilizado para verificar a existência de diferença estatisticamente significativa nas freqüências das espécies nas diferentes classes.

Para verificar a similaridade entre as diferentes classes de uso e cobertura das terras, foi feita uma analise de ordenação com coeficiente de Jaccard, que leva em conta a presença ou ausência das espécies, aplicada ao algoritmo aglomerativo UPGMA, utilizando-se o programa MVSP (Kovach 2004). 
Para verificar a diferença no uso das fitofisionomias pelas espécies, foram analisadas, para cada espécie, as freqüências de uso do habitat, por meio de um teste de qui-quadrado (Zar 1996), sendo a hipótese nula (Ho): "Não há preferência da espécie por classes de fitofisionomias" $(a=0,05)$. Quando a diferença foi significativa, utilizou-se o teste a posteriori dos limites de tolerância de Bonferroni para verificar qual a relação (negativa, positiva ou nula) das espécies com as fisionomias (Byers \& Steinhorst 1984).

\subsubsection{Freqüências dos mamíferos de médio e grande porte nos fragmentos amostrados}

Para a análise das relações entre as freqüências e a riqueza de espécies de mamíferos e os índices de paisagem obtidos para cada um dos fragmentos estudados dos fragmentos foram excluídas três das vinte e três armadilhas fotográficas utilizadas na análise acima (item 2.2.4), que estavam localizadas em áreas de passagem dentro de plantações de eucaliptos, portanto não pertencentes a nenhum dos fragmentos. Selecionaram-se sete fragmentos - dois de cerradão, dois de cerrado sensu stricto, dois de floresta semidecídua e um talhão de monocultura de eucalipto -, onde foram instaladas 20 armadilhas fotográficas (o número de câmeras em cada fragmento foi proporcional ao tamanho do fragmento), que foram verificadas a cada trinta dias, durante doze meses.

Para o cálculo da freqüência das espécies nos diferentes fragmentos, utilizamos a seguinte fórmula:

$$
F F i j=r i j / R j,
$$

onde, FFij é a freqüência da espécie i no fragmento j, rij é o número de fotografias da espécie i no fragmento j e $\mathrm{Nj}$ é o número total de fotografias de todas as espécies amostradas no fragmento j. As freqüências de uso dos habitats pelos mamíferos foram então correlacionadas por meio de uma análise de correlação de Spearman (Norman \& Streiner 1994) com os resultados das métricas por fragmento focal. 


\subsubsection{Padrão de Atividade:}

Uma vez que as armadilhas fotográficas contavam com datador, com registro de dia e hora, determinaram-se as freqüências de atividade das espécies. As fotografias obtidas foram separadas, por espécie, em quatro categorias: manhã (05:00- 11:00), tarde (11:01 - 17:00), crepúsculo (17:01: 18:00) e noite (18:01- 04:59) (Jácomo et al. 2003).

As freqüências por período foram analisadas por meio de um teste de qui-quadrado (Zar, 1996), sendo a hipótese nula (Ho): "Não há período específico do dia para maior atividade das espécies de mamíferos" $(a=0,05)$.

Quando a diferença de uso dos períodos por determinada espécie foi significativa, utilizaram-se os intervalos de confiança de Bonferroni para classificar a relação da espécie com os diferentes horários, em: positiva, negativa ou nula (Byers \& Steinhorst 1984).

Fotografias tiradas em seqüência foram contabilizadas como um registro, assim como aquelas que não puderam ter seu horário determinado.

\subsection{Resultados}

\subsubsection{Espécies de mamíferos de médio e grande porte amostradas na região:}

Foram obtidas 161 fotografias de mamíferos, 25 não identificadas e 30 seqüenciais. Foram identificadas 17 espécies, pertencentes a 14 famílias (Tabela 3). 
Tabela 3. Espécies amostradas pelas armadilhas fotográficas, grau de ameaça nas listas do IBAMA, IUCN e São Paulo (SP). (VU - Vulnerável; NT - "Near threatened")

\begin{tabular}{|c|c|c|c|c|c|}
\hline Família & Espécie & Nome comum & IBAMA & SP & IUCN \\
\hline Leporidae & $\begin{array}{l}\text { Sylvilagus } \\
\text { brasiliensis }\end{array}$ & Tapiti & - & - & - \\
\hline Tayassuidae & Pecari tajacu & Cateto & - & VU & - \\
\hline Dasypodidae & Dasypus sp. & Tatus & - & - & - \\
\hline Dasiproctidae & Dasyprocta azarae & Cotia & - & VU & VU \\
\hline Myrmecophagidae & $\begin{array}{l}\text { Myrmecophaga } \\
\text { tridactyla }\end{array}$ & $\begin{array}{l}\text { Tamanduá- } \\
\text { bandeira }\end{array}$ & VU & VU & - \\
\hline Cervidae & Mazama guazoubira & Veado-catingueiro & - & - & - \\
\hline Didelphidae & Didelphis albiventris & $\begin{array}{c}\text { Gambá-de-orelha- } \\
\text { branca }\end{array}$ & - & - & - \\
\hline Caviidae & $\begin{array}{l}\text { Hydrochoerus } \\
\text { hydrochaeris }\end{array}$ & Capivara & - & - & - \\
\hline Myrmecophagidae & $\begin{array}{l}\text { Tamandua } \\
\text { tetradactyla }\end{array}$ & Tamanduá-mirim & - & - & - \\
\hline Felidae & Puma concolor & Onça-parda & VU & VU & - \\
\hline Felidae & Leopardus pardalis & Jaguatirica & VU & VU & - \\
\hline Felidae & Puma yagouaroundi & Gato-mourisco & - & - & - \\
\hline Felidae & Leopardus tigrinus & $\begin{array}{l}\text { Gato-do-mato- } \\
\text { pequeno }\end{array}$ & VU & VU & NT \\
\hline Canidae & $\begin{array}{l}\text { Chrysocyon } \\
\text { brachyurus }\end{array}$ & Lobo-guará & VU & VU & NT \\
\hline Mustelidae & Eira barbara & Irara & - & - & - \\
\hline Procyonidae & Nasua nasua & Quati & - & - & - \\
\hline Mephitadae & $\begin{array}{l}\text { Conepatus } \\
\text { semistriatus }\end{array}$ & Jaritataca & - & - & - \\
\hline
\end{tabular}

A curva de acumulação de espécies, com 5.000 aleatorizações, mostrou que os desvios padrões tendem a se juntar e a curva central tende a estabelecer uma assíntota, o que indica a eficiência da coleta (figura 6). O estimador Bootstrap mostrou uma riqueza esperada de $17(+-0)$ espécies (figura 6), que é igual à riqueza obtida em campo. 


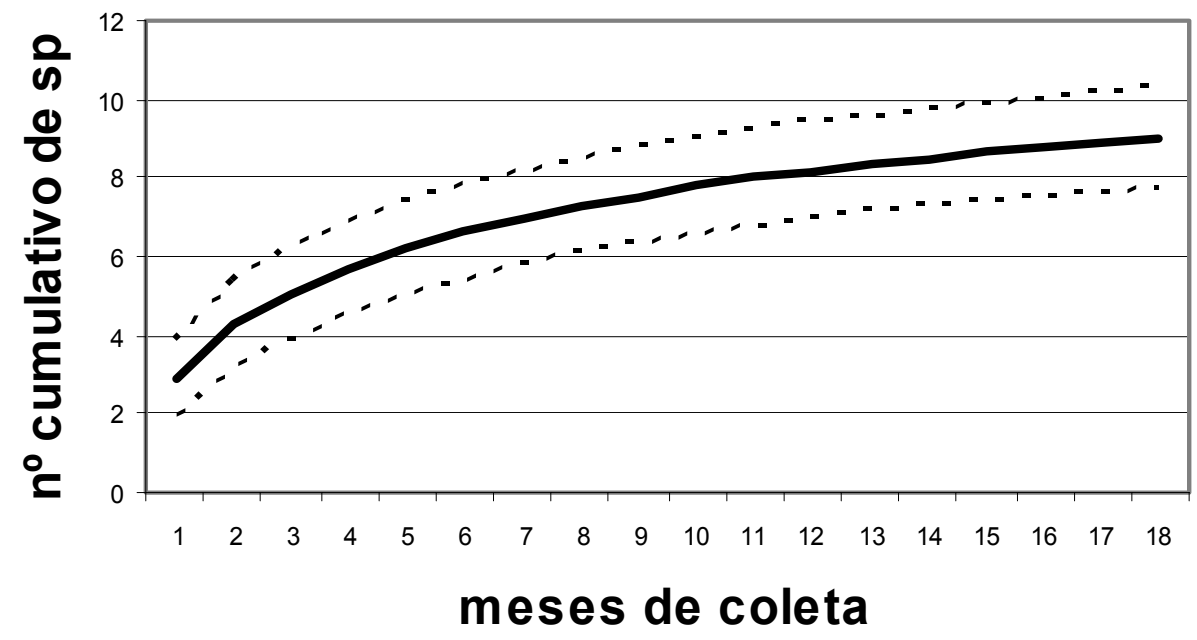

Figura 3. Curva de acumulação de espécies (Mao Tao) com 5.000 aleatorizações para a área de estudo. Em pontilhado, os desvios padrões.

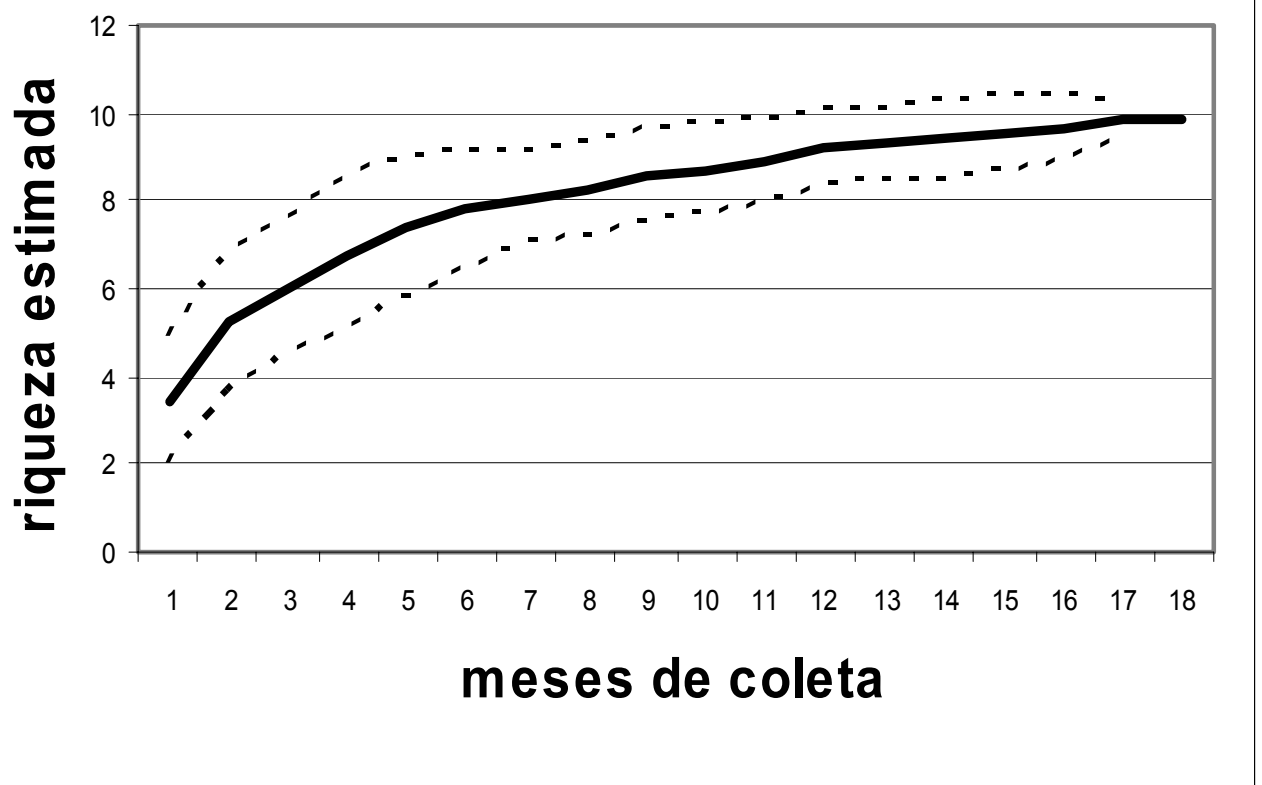

Figura 4. Curva de riqueza estimada (Bootstrap) pra a área de estudo. Em pontilhado, os desvios padrões. 


\subsubsection{Freqüências dos mamíferos de médio e grande porte por classes de uso e cobertura das terras e padrões de atividade:}

Dentre as 17 espécies de mamíferos amostradas, aquelas com maior freqüência foram: o lobo-guará (Chrysocyon brachyurus) e a onça-parda (Puma concolor) seguidos pelo cateto (Pecari tajacu) e pelo veado-catingueiro (Mazama guazoubira). $\mathrm{O}$ teste de Kruskal-Wallis indicou que as espécies utilizam de maneira diferente as fitofisionomias estudadas $(K=15,23 ; p=0,0016, n=$ 161). A fitofisionomia com maior riqueza foi o cerradão, onde foram registradas todas as 17 espécies amostradas. O cerrado sensu stricto apresentou doze espécies, o eucaliptal cinco espécies e a floresta semidecídua apenas três.

A análise de agrupamento mostrou semelhança na composição de espécies do cerradão e do cerrado sensu stricto, afastando a floresta semidecídua desses dois ambientes e isolando o eucaliptal. As relações de similaridade entre os habitats estão expressas na figura 5 e na tabela 4.

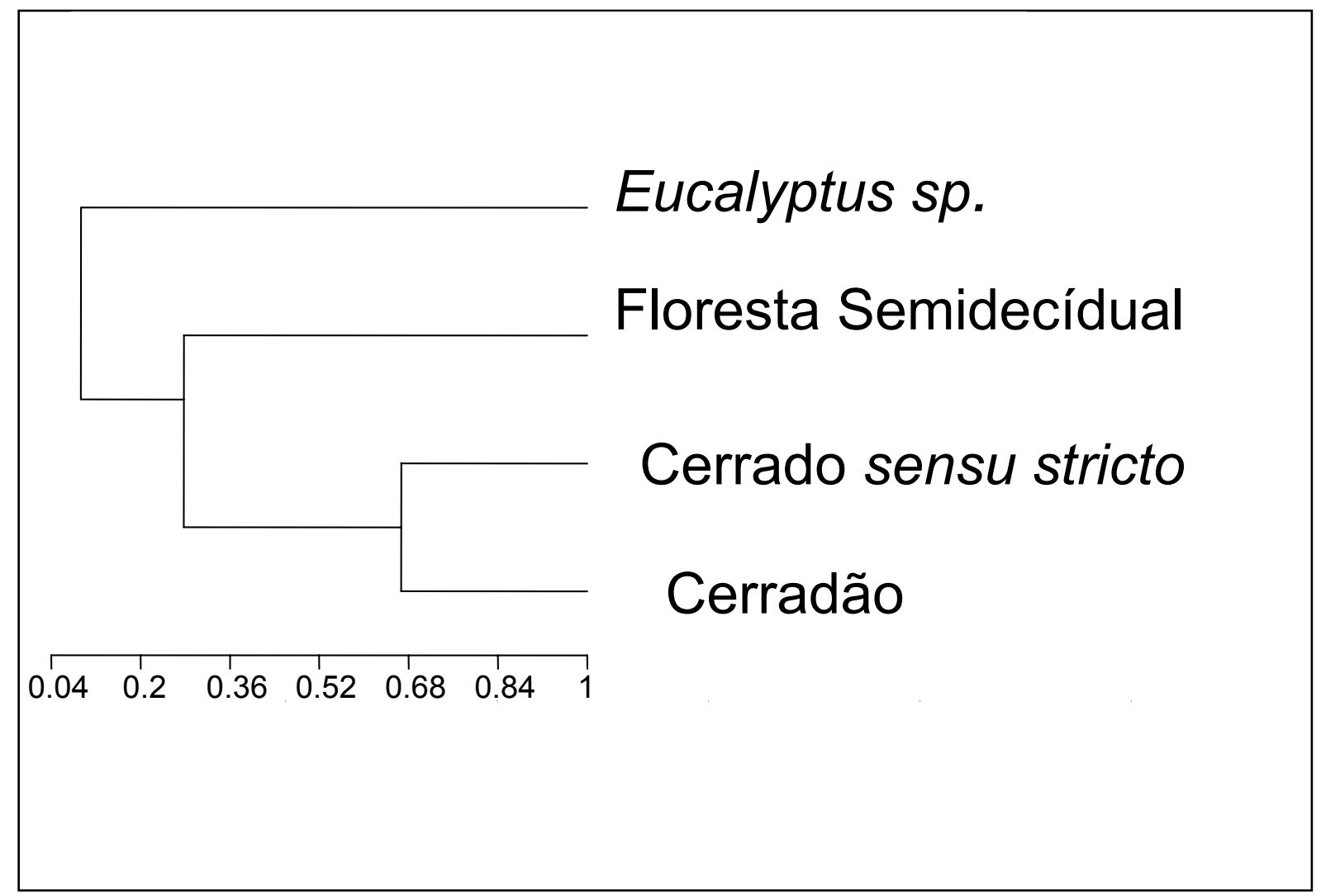

Figura 5. Dendrograma utilizando o coeficiente de Jaccard e agrupamento UPGMA, que mostra as relações de similaridade entre as fisionomias vegetais existentes na área de estudo, com base na riqueza das espécies de mamíferos de médio e grande porte amostradas. 
Tabela 4. Índices de similaridade (Jaccard) referentes à fauna de mamíferos de médio e grande porte amostrados, nos diferentes habitats, presentes na área de estudo.

\begin{tabular}{ccccc}
\hline Cerradão & $\begin{array}{c}\text { Cerrado sensu } \\
\text { stricto }\end{array}$ & $\begin{array}{c}\text { Floresta } \\
\text { semidecídua }\end{array}$ & Eucalipto \\
$\begin{array}{c}\text { Cerradão } \\
\text { Cerrado sensu } \\
\text { stricto }\end{array}$ & - & - & - & - \\
$\begin{array}{c}\text { Floresta } \\
\text { semidecídua }\end{array}$ & 0.667 & - & - & - \\
Eucalipto & 0.222 & 0.333 & - & - \\
\hline
\end{tabular}

Os resultados a seguir relatados, referentes à freqüência dos mamíferos de médio e grande porte amostrados, encontram-se na tabela 5 e os resultados dos limites de Bonferroni para as espécies com resultados significativos no teste de qui-quadrado para preferência de habitat estão na tabela 6. Quatro espécies foram detectadas exclusivamente no cerradão: Sy/vilagus brasiliensis (tapiti), Hydrochoerus hydrochaeris (capivara), Tamandua tetradactyla (tamanduámirim) e Conepatus semistriatus (jaritataca). Cinco taxa obtiveram maiores freqüências nessa fitofisionomia: Dasypus spp. (tatus), Dasyprocta azarae (cotia), Mazama guazoubira (veado catingueiro), Leopardus pardalis (jaguatirica) e Chrysocyon brachyurus (lobo-guará).

Os tatus do gênero Dasypus apresentaram $85,71 \%$ de suas fotografias obtidas no cerradão e o teste de qui-quadrado indicou uma diferença significativa no uso de habitat por essa espécie $\left(X^{2}=14.143 \mathrm{gl}=3, p<0.0027\right)$, confirmada pela relação positiva entre a freqüência de tatus e o cerradão, demonstrada pelo teste de Bonferroni. Também a cotia (Dasyprocta azarae) apresentou a grande maioria de suas fotografias $(83,33 \%)$ no cerradão, comprovando-se uma relação positiva dessa espécie com a fitofisionomia $\left(x^{2}=22.666, g l=3, p<0.000047\right)$. Dentre os registros da jaguatirica (Leopardus pardalis), 53,85\% foram encontrados no cerradão e os testes de qui-quadrado e de Bonferroni mostraram uma ligação positiva também desse felino com a fitofisionomia $\left(x^{2}=8.23, g l=3, p<0.0415\right)$.

O veado-catingueiro (Mazama guazoubira) apresentou 43,75\% de seus registros obtidos no cerradão, mas o teste de qui-quadrado não indicou preferência por nenhuma fitofisionomia $\left(x^{2}=6.5, g l=3, p<0.089\right.$ ), e o lobo-guará (Chrysocyon brachyurus), com $44,83 \%$ dos registros no 
cerradão, mostrou, por meio do teste de Bonferroni, uma relação marginalmente positiva com a fitofisionomia ( $\left.x^{2}=12.241, \mathrm{gl}=3, \mathrm{p}<0.0066\right)$. Também a onça-parda (Puma concolor), com 33,33\% dos registros no cerradão $\left(\mathrm{x}^{2}=15.2, \mathrm{gl}=3, \mathrm{p}<0.016\right)$, e o tamanduá-bandeira (Myrmecophaga tridacty/a), com 40,00\% dos registros $\left(x^{2}=10.8, g l=3, p<0.012\right)$ estabelecem uma relação nula com essa fitofisionomia.

Apesar do gambá-de-orelha-branca (Didelphis albiventris) apresentar $69,00 \%$ dos seus registros obtidos no cerradão, não demonstrou significativa preferência por algum tipo de habitat $\left(x^{2}=7.00, g l=3, p<0.071\right)$. O cateto (Pecari tajacu), com $26,60 \%$ de suas fotografias obtidas no cerradão, não demonstrou ligação com nenhuma das fitofisionomias amostradas $\left(x^{2}=5.533 \mathrm{gl}=3\right.$, p $<0.136$ ), assim como a irara (Eira barbara), com $33,33 \%$ de aparecimentos no cerradão ( $X$ ${ }^{2}=3.66, \mathrm{gl}=3, \mathrm{p}<0.29$ ). Apenas duas espécies, Nasua nasua (quati) e Leopardus tigrinus (gato-domato-pequeno), foram exclusivas do cerrado sensu stricto.

O tamanduá-bandeira (Myrmecophaga tridactyla) foi a única espécie a obter uma relação positiva com o cerrado sensu stricto, com $60,00 \%$ dos registros obtidos nessa fitofisionomia. $S$. brasiliensis, H. hydrochaeris, T. tetradactyla e Puma yagaoroundi (gato-mourisco) não obtiveram nenhum registro nessa fitofisionomia. Todas as outras espécies mostraram uma relação nula com o cerrado sensu stricto e nenhuma espécie apresentou ligação negativa com a fitofisionomia.

Nenhuma espécie foi exclusiva da floresta semidecídua. $P$. tajacu obteve a maior porcentagem de uso para essa fitofisionomia $(40,00 \%)$, seguido de $D$. albiventris $(12,50 \%)$ e $P$. concolor $(7,41 \%)$. As demais espécies não foram registradas pelas armadilhas fotográficas nessa fitofisionomia.

Apenas $P$. yagoauroundi foi exclusiva das áreas de reflorestamento com eucaliptos. $P$. concolor apresentou $51,65 \%$ de seus registros nessa monocultura e os limites de Bonferroni indicaram uma relação positiva com o reflorestamento $\left(x^{2}=15.22, g l=3, p<0.016\right)$. 
Tabela 5. Porcentagens de uso, das fitofisionomias amostradas, pelos mamíferos de médio e grande porte e número de fotografias (n) em cada tipo de classe amostrada.

\begin{tabular}{|c|c|c|c|c|}
\hline & $\begin{array}{c}\text { Cerradão } \\
\% \text { (n) }\end{array}$ & $\begin{array}{l}\text { Cerrado Sensu } \\
\text { Stricto } \% \text { (n) }\end{array}$ & $\begin{array}{c}\text { Floresta Semidecídua } \\
\% \text { (n) }\end{array}$ & $\begin{array}{c}\text { Eucalipto } \% \\
\text { (n) }\end{array}$ \\
\hline Sylvilagus brasiliensis & $100,00(9)$ & $0,00(0)$ & $0,00(0)$ & $0,00(0)$ \\
\hline Pecari tajacu & $26,60(4)$ & $33,33(5)$ & $40,00(6)$ & $0,00(0)$ \\
\hline Dasypus sp. & $85,71(6)$ & $14,29(1)$ & $0,00(0)$ & $0,00(0)$ \\
\hline Dasyprocta azarae & $83,33(10)$ & $16,67(2)$ & $0,00(0)$ & $0,00(0)$ \\
\hline $\begin{array}{c}\text { Myrmecophaga } \\
\text { tridactyla }\end{array}$ & $40,00(4)$ & $60,00(6)$ & $0,00(0)$ & $0,00(0)$ \\
\hline Mazama guazoubira & $43,75(7)$ & $25,00(4)$ & $0,00(0)$ & $31,25(5)$ \\
\hline Didelphis albiventris & $62,50(5)$ & $25,00(2)$ & $12,50(1)$ & $0,00(0)$ \\
\hline $\begin{array}{c}\text { Hydrochoerus } \\
\text { hydrochaeris }\end{array}$ & $100,00(1)$ & $0,00(0)$ & $0,00(0)$ & $0,00(0)$ \\
\hline $\begin{array}{l}\text { Tamandua } \\
\text { tetradactyla }\end{array}$ & $100,00(1)$ & $0,00(0)$ & $0,00(0)$ & $0,00(0)$ \\
\hline Puma concolor & $33,33(9)$ & $7,41(2)$ & $7,41(2)$ & $51,85(14)$ \\
\hline Leopardus pardalis & $53,85(7)$ & 30,77 (4) & $0,00(0)$ & $15,38(2)$ \\
\hline Puma yagouaroundi & $0,00(0)$ & $0,00(0)$ & $0,00(0)$ & $100,00(3)$ \\
\hline Leopardus tigrinus & $0,00(0)$ & $100,00(1)$ & $0,00(0)$ & $0,00(0)$ \\
\hline $\begin{array}{l}\text { Chrysocyon } \\
\text { brachyurus }\end{array}$ & $44,83(13)$ & $31,03(9)$ & $0,00(0)$ & $24,14(7)$ \\
\hline Eira barbara & $33,33(1)$ & $66,67(2)$ & $0,00(0)$ & $0,00(0)$ \\
\hline Nasua nasua & $0,00(0)$ & $100,00(2)$ & $0,00(0)$ & $0,00(0)$ \\
\hline $\begin{array}{c}\text { Conepatus } \\
\text { semistriatus }\end{array}$ & $100,00(3)$ & $0,00(0)$ & $0,00(0)$ & $0,00(0)$ \\
\hline
\end{tabular}


Tabela 6. Valores observados e esperados das freqüências dos mamíferos de médio e grande porte amostrados com diferenças significativas para o uso de fitofisionomias, limites de Bonferroni e relação (positiva, negativa ou nula) das espécies com as classes de fisionomias vegetais amostradas.

\begin{tabular}{|c|c|c|c|c|c|}
\hline & & $\begin{array}{c}\text { Freqüência } \\
\text { observada }\end{array}$ & $\begin{array}{c}\text { Freqüência } \\
\text { esperada }\end{array}$ & Limites de Bonferroni & Relação \\
\hline \multirow{5}{*}{ Dasypus sp. } & "Cerradão" & 0,85 & 0,25 & $0.625<\mathrm{p} 1<1$ & positiva \\
\hline & $\begin{array}{l}\text { "Cerrado" sensu } \\
\text { stricto }\end{array}$ & 0,14 & 0,25 & $0<\mathrm{p} 2<0.374$ & nula \\
\hline & $\begin{array}{c}\text { Floresta } \\
\text { Semidecídua }\end{array}$ & 0 & 0,25 & $0<\mathrm{p} 3<0.232$ & negativa \\
\hline & Eucaliptos & 0 & 0,25 & $\mathrm{o}<\mathrm{p} 4<0.232$ & negativa \\
\hline & "Cerradão" & 0,83 & 0,25 & $0.601<\mathrm{p} 1<1$ & positiva \\
\hline \multirow{4}{*}{$\begin{array}{c}\text { Dasyprocta } \\
\text { azarae }\end{array}$} & $\begin{array}{l}\text { Cerrado sensu } \\
\text { stricto }\end{array}$ & 0,16 & 0,25 & $0<\mathrm{p} 2<0.398$ & nula \\
\hline & $\begin{array}{c}\text { Floresta } \\
\text { Semidecídua }\end{array}$ & 0 & 0,25 & $0<\mathrm{p} 3<0.232$ & negativa \\
\hline & Eucaliptos & 0 & 0,25 & $\mathrm{o}<\mathrm{p} 4<0.232$ & negativa \\
\hline & Cerradão & 0,4 & 0,25 & $0.168<\mathrm{p} 1<0.632$ & nula \\
\hline \multirow{4}{*}{$\begin{array}{c}\text { Myrmecophaga } \\
\text { tridactyla }\end{array}$} & $\begin{array}{l}\text { Cerrado sensu } \\
\text { stricto }\end{array}$ & 0,6 & 0,25 & $0.368<\mathrm{p} 2<0.832$ & positiva \\
\hline & $\begin{array}{c}\text { Floresta } \\
\text { Semidecídua }\end{array}$ & 0 & 0,25 & $0<\mathrm{p} 3<0.232$ & negativa \\
\hline & Eucaliptos & 0 & 0,25 & $0<\mathrm{p} 3<0.232$ & negativa \\
\hline & Cerradão & 0,33 & 0,25 & $0.098<\mathrm{p} 1<0.562$ & nula \\
\hline \multirow{4}{*}{ Puma concolor } & $\begin{array}{l}\text { Cerrado sensu } \\
\text { stricto }\end{array}$ & 0,07 & 0,25 & $0<\mathrm{p} 2<0.302$ & nula \\
\hline & $\begin{array}{c}\text { Floresta } \\
\text { Semidecídua }\end{array}$ & 0,07 & 0,25 & $0<\mathrm{p} 3<0.302$ & nula \\
\hline & Eucaliptos & 0,51 & 0,25 & $0.288<\mathrm{p} 4<0.752$ & positiva \\
\hline & Cerradão & 0,53 & 0,25 & $0.308<\mathrm{p} 1<0.772$ & positiva \\
\hline \multirow{3}{*}{$\begin{array}{l}\text { Leopardus } \\
\text { pardalis }\end{array}$} & $\begin{array}{l}\text { Cerrado sensu } \\
\quad \text { stricto }\end{array}$ & 0,30 & 0,25 & $0.078<\mathrm{p} 2<0.532$ & nula \\
\hline & $\begin{array}{c}\text { Floresta } \\
\text { Semidecídua }\end{array}$ & 0 & 0,25 & $0<\mathrm{p} 3<0.232$ & negativa \\
\hline & Eucaliptos & 0,15 & 0,25 & $0<\mathrm{p} 4<0.382$ & nula \\
\hline \multirow{4}{*}{$\begin{array}{l}\text { Chrysocyon } \\
\text { brachyurus }\end{array}$} & Cerradão & 0,44 & 0,25 & $0.218<\mathrm{p} 1<0.682$ & nula \\
\hline & $\begin{array}{l}\text { Cerrado sensu } \\
\quad \text { stricto }\end{array}$ & 0,31 & 0,25 & $0.078<\mathrm{p} 2<0.542$ & nula \\
\hline & $\begin{array}{c}\text { Floresta } \\
\text { Semidecídua }\end{array}$ & 0 & 0,25 & $0<\mathrm{p} 3<0.232$ & negativa \\
\hline & Eucaliptos & 0,241 & 0,25 & $0.008<\mathrm{p} 4<0.472$ & nula \\
\hline
\end{tabular}

Em relação aos padrões de atividade (tabela 7 e tabela 8 ), cinco espécies - o tapiti ( $S$. brasiliensis), o gambá-de-orelha-branca ( $D$. albiventris), a capivara ( $H$. hydrochaeris), o gato-domato-pequeno (L. tigrinus) e a jaritataca (C. semistriatus) - foram detectadas exclusivamente à noite. O quati ( $N$. nassua) foi detectado apenas de manhã. A onça-parda ( $P$. concolor) $\left(X^{2}=42.19\right.$, $\mathrm{gl}=3, \mathrm{p}<0.000)$ e a jaguatirica (L. pardalis) $\left(\mathrm{X}^{2}=16.28, \mathrm{gl}=3, \mathrm{p}<0.002\right)$ obtiveram 76,00 e $76,92 \%$, respectivamente, de suas fotografias no período noturno e os limites de Bonferroni indicaram uma 
relação positiva como esse período. A onça-parda ainda apresentou relação negativa com o período da tarde e a jaguatirica com o crepúsculo.

Oitenta e cinco por cento das fotografias de tatus do gênero Dasypus foram obtidas à noite e $15,00 \%$ à tarde $\left(x^{2}=14.143, g l=3, p<0,0027\right)$. Essas espécies apresentaram uma relação positiva com o período noturno e negativa com a manhã e o crepúsculo. Também o lobo-guará ( $C$. brachyurus), com $62,96 \%$ das suas fotografias obtidas à noite $\left(x^{2}=29.46 \mathrm{gl}=3, \mathrm{p}<0.000\right)$, apresentou relação positiva com esse período. Ainda de hábito preferencialmente noturno, foi encontrado o tamanduá-bandeira ( $M$. tridactyla), com $10,00 \%$ de suas fotografias obtidas no período da tarde, $20,00 \%$ no crepúsculo e $70,00 \%$ à noite $\left(x^{2}=11.6, g l=3, p<0.0089\right)$, mostrando uma relação positiva com o período noturno e negativa com a manhã.

Para o veado-catingueiro (M. guazoubira), $68,75 \%$ das fotografias foram obtidas pela manhã, enquanto que $31,25 \%$ foram obtidas à noite. $O$ teste de qui-quadrado rejeitou Ho $\left(x^{2}=20.5, g l=3, p<0.0001\right)$ e a espécie revelou uma relação positiva com a manhã e negativa com a tarde e o crepúsculo, porém nula com o período noturno.

O cateto ( $P$. tajacu) apresentou $33,33 \%$ das suas fotografias no período noturno, seguido de $26,67 \%$ na parte da tarde e $20,00 \%$ na manhã e no crepúsculo, sendo que a espécie não demonstrou preferência por período $\left(\mathrm{x}^{2}=2.529, \mathrm{gl}=3, \mathrm{p}<0.47\right)$. Também a cotia $(D$. azarae $)$ não revelou preferência por algum período $\left(x^{2}=5.333, g l=3, p<0.149\right)$, tendo-se obtido $8,33 \%$ das fotografias nos períodos da manhã e da tarde, e $41,67 \%$ das fotografias nos períodos do crepúsculo e noite. Entretanto, quando agrupados em apenas dois períodos, um com alta luminosidade (manhã e tarde) e outro com baixa luminosidade (crepúsculo e noite), foi encontrada uma diferença significativa $\left(x^{2}=5.333, g l=1, p<0.02\right)$, mostrando uma relação positiva das fotografias obtidas com os períodos de menor luminosidade.

O gato-mourisco ( $P$. yagouaround $l$ ) obteve $33,33 \%$ das fotografias tanto no período da manhã, quanto no crepúsculo e à noite. $O$ teste de qui-quadrado $\left(x^{2}=1.00 \mathrm{gl}=1, \mathrm{p}<0.83\right)$ indicou falta de preferência por horários. O mesmo ocorreu com a irara ( $E$. barbara), para quem $66,66 \%$ das fotografias foram obtidas de manha e $33,33 \%$ à tarde $\left(x^{2}=3.36, g l=1, p<0.29\right)$. 
Tabela 7. Porcentagens, nos períodos de atividade amostrados dos mamíferos de médio e grande porte e número de fotografias $(\mathrm{n})$.

\begin{tabular}{|c|c|c|c|c|}
\hline & $\begin{array}{c}\text { Manha }(05: 00-11: 00) \\
\%(\mathrm{n})\end{array}$ & $\begin{array}{c}\text { Tarde (11:01-17:00) } \\
\%(\mathrm{n})\end{array}$ & $\begin{array}{c}\text { Crepúsculo (17:01-18:00) } \\
\%(\mathrm{n})\end{array}$ & $\begin{array}{c}\text { Noite (18:01-04:59) } \\
\% \text { (n) }\end{array}$ \\
\hline $\begin{array}{c}\text { Sylvilagus } \\
\text { brasiliensis }\end{array}$ & $0,00(0)$ & $0,00(0)$ & $0,00(0)$ & $100,00(9)$ \\
\hline Pecari tajacu & $20,00(3)$ & $26,67(4)$ & $20,00(3)$ & $33,33(5)$ \\
\hline Dasypus sp. & $0,00(0)$ & $14,29(1)$ & $0,00(0)$ & $85,71(6)$ \\
\hline Dasyprocta azarae & $8,33(1)$ & $8,33(1)$ & $41,67(5)$ & $41,67(5)$ \\
\hline $\begin{array}{l}\text { Myrmecophaga } \\
\text { tridactyla }\end{array}$ & $0,00(0)$ & $10,00(1)$ & $20,00(2)$ & $70,00(7)$ \\
\hline $\begin{array}{c}\text { Mazama } \\
\text { guazoubira }\end{array}$ & $68,75(11)$ & $0,00(0)$ & $0,00(0)$ & $31,25(5)$ \\
\hline $\begin{array}{c}\text { Didelphis } \\
\text { albiventris }\end{array}$ & $0,00(0)$ & $0,00(0)$ & $0,00(0)$ & $100,00(8)$ \\
\hline $\begin{array}{c}\text { Hydrochoerus } \\
\text { hydrochaeris }\end{array}$ & $0,00(0)$ & $0,00(0)$ & $0,00(0)$ & $100,00(1)$ \\
\hline $\begin{array}{c}\text { Tamandua } \\
\text { tetradactyla }\end{array}$ & $100,00(1)$ & $0,00(0)$ & $0,00(0)$ & $0,00(0)$ \\
\hline Puma concolor & $20,00(5)$ & $0,00(0)$ & $4,00(1)$ & 76,00 (19) \\
\hline Leopardus pardalis & $7,69(1)$ & $15,38(2)$ & $0,00(0)$ & $76,92(10)$ \\
\hline $\begin{array}{c}\text { Puma } \\
\text { yagouaroundi }\end{array}$ & $33,33(1)$ & $0,00(0)$ & $33,33(1)$ & $33,33(1)$ \\
\hline Leopardus tigrinus & $0,00(0)$ & $0,00(0)$ & $0,00(0)$ & $100,00(1)$ \\
\hline $\begin{array}{l}\text { Chrysocyon } \\
\text { brachyurus }\end{array}$ & $3,70(1)$ & $11,11(3)$ & $22,22(6)$ & $62,96(17)$ \\
\hline Eira barbara & $66,66(4)$ & $0,00(0)$ & $0,00(0)$ & $33,33(2)$ \\
\hline Nassua nassua & $100,00(2)$ & $0,00(0)$ & $0,00(0)$ & $0,00(0)$ \\
\hline $\begin{array}{c}\text { Conepatus } \\
\text { semistriatus }\end{array}$ & $0,00(0)$ & $0,00(0)$ & $0,00(0)$ & $100,00(3)$ \\
\hline
\end{tabular}


Tabela 8. Valores observados e esperados das freqüências dos mamíferos de médio e grande porte amostrados com diferenças significativas para o uso dos períodos de atividade limites de Bonferroni e relação (positiva, negativa ou nula) das espécies com os períodos de atividade amostrados.

\begin{tabular}{|c|c|c|c|c|c|}
\hline & & $\begin{array}{c}\text { Freqüência } \\
\text { observada }\end{array}$ & $\begin{array}{c}\text { Freqüência } \\
\text { esperada }\end{array}$ & $\begin{array}{l}\text { Limites de } \\
\text { Bonferroni }\end{array}$ & Relação \\
\hline & Manhã & 0,19 & 0,25 & $0<\mathrm{p} 1<0.417$ & nulo \\
\hline & Tarde & 0,00 & 0,25 & $0<\mathrm{p} 2<0.232$ & negativo \\
\hline \multicolumn{6}{|l|}{ Puma concolor } \\
\hline & Crepúsculo & 0,04 & 0,25 & $0<\mathrm{p} 3<0.269$ & nulo \\
\hline & Noite & 0,78 & 0,25 & $0.546<\mathrm{p} 4<1$ & positivo \\
\hline & Manhã & 0,08 & 0,25 & $0<\mathrm{p} 1<0.309$ & nulo \\
\hline & Tarde & 0,15 & 0,25 & $0<\mathrm{p} 2<0.386$ & nulo \\
\hline \multicolumn{6}{|c|}{ Leopardus pardalis } \\
\hline & Crepúsculo & 0,00 & 0,25 & $0<\mathrm{p} 3<0.232$ & negativo \\
\hline & Noite & 0,77 & 0,25 & $0.537<\mathrm{p} 4<1$ & positivo \\
\hline & Manhã & 0,03 & 0,25 & $0<\mathrm{p} 1<0.265$ & nulo \\
\hline & Tarde & 0,10 & 0,25 & $0<\mathrm{p} 2<0.332$ & nulo \\
\hline \multirow[t]{4}{*}{$\begin{array}{l}\text { Chrysocyon } \\
\text { brachyurus }\end{array}$} & Crepúsculo & 0,20 & 0,25 & $0<\mathrm{p} 3<0.423$ & nulo \\
\hline & Noite & 0,67 & 0,25 & $0.435<\mathrm{p} 4<0.899$ & positivo \\
\hline & Manhã & 0 & 0,25 & $0<\mathrm{p} 1<0.232$ & negativo \\
\hline & Tarde & 0,14 & 0,25 & $0<\mathrm{p} 2<0.372$ & nulo \\
\hline \multicolumn{6}{|l|}{ Dasypus sp. } \\
\hline & Crepúsculo & 0 & 0,25 & $0<\mathrm{p} 3<0.232$ & negativo \\
\hline & Noite & 0,85 & 0,25 & $0.628<\mathrm{p} 4<1$ & positivo \\
\hline & Manhã & 0 & 0,25 & $0<\mathrm{p} 1<0.232$ & negativo \\
\hline \multirow{5}{*}{$\begin{array}{c}\text { Myrmecophagc } \\
\text { tridactyla }\end{array}$} & Tarde & 0,1 & 0,25 & $0<\mathrm{p} 2<0.51$ & nulo \\
\hline & Crepúsculo & 0,2 & 0,25 & $0<\mathrm{p} 3<0.61$ & nulo \\
\hline & Noite & 0,7 & 0,25 & $0.468<\mathrm{p} 4<0.923$ & positivo \\
\hline & Manhã & 0,68 & 0,25 & $0.455<\mathrm{p} 1<0.9195$ & positivo \\
\hline & Tarde & 0 & 0,25 & $0<\mathrm{p} 2<0.232$ & negativo \\
\hline \multicolumn{6}{|c|}{ Mazama guazoubira } \\
\hline & Crepúsculo & 0 & 0,25 & $0<\mathrm{p} 3<0.232$ & negativo \\
\hline & Noite & 0,31 & 0,25 & $0.078<\mathrm{p} 4<0.542$ & nulo \\
\hline
\end{tabular}




\subsubsection{Relação entre a freqüência dos mamíferos amostrados com as características estruturais dos fragmentos}

As métricas da paisagem (tabela 9) mostram que o talhão de eucaliptos (EU) possui a melhor relação perímetro/área $(P A R A=0.002)$, indicando menos bordas expostas em relação à sua área total; além disso, o índice de proximidade (PROX = 19251,3) mostra que é o fragmento com maior número de remanescentes de mesma cobertura vegetal, grandes e próximas.

A EEJ dista da mais próxima área de mesma classe (ENN) $30 \mathrm{~m}$, possui PARA baixo (0.093), indicando uma forma próxima a um círculo, e faz borda com grandes áreas de plantio de eucalipto (843,4 ha) e de pastagem (458 ha). É o maior fragmento estudado (7.822 ha).

O fragmento OI também apresentou baixa relação perímetro/área $(0.082)$ e grandes plantios de eucaliptos (2.556 ha) adjacentes a ele. Seu vizinho mais próximo (ENN) está a apenas $30 \mathrm{~m}$.

O fragmento Tamanduá (TD) é o menor estudado (132 ha), não faz divisa com plantios de eucaliptos ou pastos, possui baixa relação perímetro/área (0.229), dista 117,1 m (ENN) do fragmento de cerrado sensu stricto mais próximo, caracterizando-se como o fragmento de cerrado estudado, mais isolado (estruturalmente).

O fragmento PG também é relativamente isolado de outros fragmentos de cerrado $(E N N=$ $87,4 \mathrm{~m}$ ) e é o que possui as menores áreas de cerrado próximas a ele (PROX $=148,9)$; possui média relação perímetro/área $(0,587)$ e faz divisa com uma grande monocultura de eucaliptos (5.364 ha).

Os fragmentos florestais PR e CP são os mais isolados funcional e estruturalmente, pois apesar de distarem 30 e 94 m (ENN), respectivamente, de outras áreas de floresta semidecídua, estas são muito pequenas e não significativas na paisagem (PROX $=11,0$ e 8,0, respectivamente). Ambos não fazem divisa com áreas de pastagem ou plantios de eucaliptos. 
Tabela 9. Resultados dos cálculos das variáveis da paisagem (métricas) para os fragmentos focais na área de estudo.

\begin{tabular}{cccccccc}
\hline & $\begin{array}{c}\text { Área } \\
\text { (ha) }\end{array}$ & $\begin{array}{c}\text { Prox (sem } \\
\text { unidade) }\end{array}$ & $\begin{array}{c}\text { ENN } \\
\text { (metros) }\end{array}$ & $\begin{array}{c}\text { PARA } \\
\text { (sem } \\
\text { unidade) }\end{array}$ & EucA (ha) & $\begin{array}{c}\text { PasP } \\
\text { (metros) }\end{array}$ & $\begin{array}{c}\text { PasA } \\
\text { (ha) }\end{array}$ \\
Jataí (EEJ) & 7822,0 & 324,2 & 30,0 & 0,093 & 843,4 & 193,9 & 458,6 \\
Oitocentos (OI) & 1566,1 & 365,9 & 30,0 & 0,082 & 2556,0 & 3978,0 & 458,6 \\
Tamanduá (TD) & 132,1 & 511,3 & 117,2 & 0,229 & 0,0 & 0,0 & 0,0 \\
Pé-de-gigante (PG) & 1215,5 & 149,0 & 87,5 & 0,587 & 5364,9 & 0,0 & 0,0 \\
Praxedes (PR) & 163,4 & 11,1 & 30,0 & 2,710 & 0,0 & 0,0 & 0,0 \\
Capetinga (CP) & 325,9 & 8,1 & 94,9 & 11,775 & 0,0 & 0,0 & 0,0 \\
Eucalipto(1-2) & & & & & & & \\
(EU) & 829,8 & 19251,3 & 30,0 & 0,002 & 829,8 & 0,0 & 0,0 \\
\hline
\end{tabular}

A correlação de Spearman entre as freqüências dos mamíferos estudados (espécies que obtiveram mais de 10 registros fotográficos) e as variáveis estruturais dos fragmentos amostrados mostrou que a configuração da paisagem influencia a freqüência das espécies por fragmento, especialmente devido às seguintes variáveis, dentre as analisadas: área de pastagem adjacente ao fragmento focal (PasA), perímetro de pastagem adjacente ao fragmento focal (PasP), relação perímetro / área (PARA), distância mais próxima ao vizinho de mesma classe (ENN), tamanho da área (Área) e proximidade a fragmentos de mesma fisionomia (PROX). As freqüências obtidas por espécie e fragmento e as correlações com as métricas encontram-se na figura 10 e tabela 8 (excluídos os coeficientes de correlação com valores abaixo de 0.7).

O lobo-guará ( $C$. brachyurus) apresentou correlação positiva com PasP, PasA e Área (respectivamente, $0.764,0.809,0.846)$ e negativa com PARA $(-0.828)$.

O veado-catingueiro (M. guazoubira) e a jaguatirica (L. pardalis) apresentaram correlação com o índice PROX (respectivamente 0.81 e 0.775 ) e o cateto ( $P$. tajacu) apresentou correlação significativa com ENN (0.856).

A onça-parda ( $P$. concolor), o gambá-de-orelha-branca (Didelphis albiventris) o tamanduábandeira ( $M$. tridactyla) não apresentaram correlação significativa com nenhuma das métricas analisadas. 
Dentre as métricas da paisagem analisadas, as que mostraram correlação significativa com a riqueza de espécies foram: área de eucalipto adjacente ao fragmento (EucA $=0.876)$, Área total do fragmento (Área $=0.77$ ) e relação perímetro - área (PARA $=-0.899)$.

Tabela 10. Porcentagens de uso dos fragmentos, pelos mamíferos de médio e grande porte, com mais de 9 fotografias obtidas no estudo e número de fotos.

\begin{tabular}{|c|c|c|c|c|c|c|c|}
\hline & $\begin{array}{l}\text { "Jataí" } \\
\%(n)\end{array}$ & $\begin{array}{c}800 \\
\text { Alqueires" } \\
\%(n)\end{array}$ & $\begin{array}{l}\text { "Tamanduá" } \\
\text { \% (n) }\end{array}$ & $\begin{array}{l}\text { "Pé-de- } \\
\text { Gigante" } \\
\% \text { (n) }\end{array}$ & $\begin{array}{l}\text { "Praxedes" } \\
\text { \% (n) }\end{array}$ & $\begin{array}{c}\text { "Capetinga" } \\
\% \text { (n) }\end{array}$ & $\begin{array}{c}\text { "Eucaliptos" } \\
\% \text { (n) }\end{array}$ \\
\hline $\begin{array}{l}\text { Chrysocyon } \\
\text { brachyurus }\end{array}$ & $54,55(18)$ & $12,12(4)$ & $3,03(1)$ & $15,15(5)$ & $0,00(0)$ & $0,00(0)$ & $15,15(5)$ \\
\hline Puma concolor & $30,30(10$ & $3,03(1)$ & $0,00(0)$ & $18,18(6)$ & $6,06(2)$ & $0,00(0)$ & $42,42(14)$ \\
\hline $\begin{array}{l}\text { Leopardus } \\
\text { pardalis }\end{array}$ & $46,67(7)$ & $20,00(3)$ & $20,00(3)$ & $6,67(1)$ & $0,00(0)$ & $0,00(0)$ & $6,67(1)$ \\
\hline $\begin{array}{l}\text { Didelphis } \\
\text { albiventris }\end{array}$ & $44,44(4)$ & $33,33(3)$ & $0,00(0)$ & $11,11(1)$ & $11,11(1)$ & $0,00(0)$ & $0,00(0)$ \\
\hline $\begin{array}{c}\text { Mazama } \\
\text { guazoubira }\end{array}$ & $13,33(2)$ & $33,33(5)$ & $13,33(2)$ & $20,00(3)$ & $0,00(0)$ & $0,00(0)$ & $20,00(3)$ \\
\hline $\begin{array}{c}\text { Myrmecophaga } \\
\text { tridactyla }\end{array}$ & $28,57(4)$ & $7,14(1)$ & $7,14(1)$ & $50,00(7)$ & $0,00(0)$ & $0,00(0)$ & $7,14(1)$ \\
\hline Pecari tajacu & $25,00(3)$ & $0,00(0)$ & $33,33(4)$ & $8,33(1)$ & $0,00(0)$ & $33,33(0)$ & $0,00(0)$ \\
\hline $\begin{array}{l}\text { Total por } \\
\text { fragmento }\end{array}$ & $37,80(48)$ & $13,39(17)$ & $5,51(7)$ & $18,90(24)$ & $2,36(3)$ & $3,15(4)$ & $18,90(24)$ \\
\hline
\end{tabular}

Tabela 11. Valores superiores a 0,7 dos coeficientes de correlação de Spearman entre freqüência e riqueza de mamíferos e as métricas de paisagem utilizadas (NS - não significativo).

\begin{tabular}{|c|c|c|c|c|c|c|c|}
\hline & EucA & PasP & PasA & Area & PARA & Prox & ENN \\
\hline $\begin{array}{l}\text { Chrysocyon } \\
\text { brachyurus }\end{array}$ & NS & 0,764 & 0,809 & 0,846 & $-0,828$ & NS & NS \\
\hline Puma concolor & NS & NS & NS & NS & NS & NS & NS \\
\hline Leopardus pardalis & NS & NS & NS & NS & NS & 0,775 & NS \\
\hline Didelphis albiventris & NS & NS & NS & NS & NS & NS & NS \\
\hline Mazama guazoubira & NS & NS & NS & NS & NS & 0,810 & NS \\
\hline $\begin{array}{c}\text { Myrmecophaga } \\
\text { tridactyla }\end{array}$ & NS & NS & NS & NS & NS & NS & NS \\
\hline Pecari tajacu & NS & NS & NS & NS & NS & NS & 0,856 \\
\hline Riqueza de espécies & 0,876 & NS & NS & 0,77 & $-0,899$ & NS & NS \\
\hline
\end{tabular}




\subsection{Discussão:}

Sete espécies, a capivara (Hydrochoerus hydrochaeris), o tamanduá-mirim (Tamandua tetradactyla), o gato-mourisco (Puma yagouaroundi), o gato-do-mato-pequeno (Leopardus tigrinus), o quati (Nasua nasua), a irara (Eira barbara) e a jaritataca (Conepatus semistriatus) foram fotografadas menos de três vezes, o que comprometeu as análises estatísticas e, desta forma, não foi possível fazer maiores inferências sobre seu comportamento.

Todas as espécies amostradas neste estudo também foram encontradas em outros levantamentos realizados na região (Lyra-Jorge 1999, Talamoni et al. 2000; Lyra-Jorge 2007). Algumas espécies encontradas em outros trabalhos não foram amostradas neste, pois o método do armadilhamento fotográfico, da forma como foi utilizado neste trabalho, é eficaz para espécies terrestres de médio a grande porte e de hábitos cursoriais. Portanto, espécies arborícolas, como os primatas e certos felinos (como o gato-maracajá, Leopardus wiedii), espécies com habitats muito específicos, como a lontra (Lontra longicaudis) e espécies muito raras na região, como a raposinha-do-campo (Lycalopex vetulus), não foram fotografadas. Não houve diferença significativa na riqueza de espécies encontradas nas áreas protegidas e nas não protegidas, o que reforça a teoria dos mosaicos em relação à das grandes áreas (Metzger 2006), pois as áreas protegidas legalmente pelos órgãos governamentais em unidades de conservação não são diferentes das áreas não protegidas pois as espécies de mamíferos de médio e grande porte parecem utilizar a área como um todo.

O padrão de uso de habitat pela maioria das espécies mostrou-se fortemente ligado às fisionomias de cerrado, indicando a importância da conservação desse bioma. As relações geradas pela análise de agrupamento indicaram que o cerrado sensu stricto e o cerradão possuem mais espécies em comum entre si do que com as outras fisionomias estudadas, o que era esperado se considerarmos a semelhança florística entre esses ambientes, mas que diferem quanto à estrutura da vegetação. Esta análise também separou das fisionomias de cerrado tanto a floresta semidecídua como o eucaliptal, que apresentaram riquezas bem menores. No entanto, a relativa proximidade destas duas fisionomias (floresta semidecídua e eucaliptal) deve ser devida justamente à sua estrutura florestal. Apesar dos plantios de eucaliptos serem monoespecíficos e 
constituídos por espécies exóticas, o que os tornam menos procurados pelas espécies da fauna nativa, eles compõem a matriz de quase todos os fragmentos na paisagem estudada, servindo como ambiente (passagem, habitat) para algumas espécies que se adaptaram a essa floresta exótica.

Sy/vilagus brasiliensis (tapiti) foi detectado apenas no cerradão. Isso corrobora outros trabalhos que mostram que a espécie é exclusiva de fitofisionomias florestais (Trolle \& Kéry 2005, Srbek-Araújo \& Chiarello 2007). Levando-se isso em conta, a espécie deveria ter sido detectada também nas áreas de floresta semidecídua, mas provavelmente pelo fato dos remanescentes dessa fisionomia estarem isolados há muito tempo, sofrerem grandes pressões antrópicas - por estarem envolvidos por monoculturas de cana-de-açúcar, cujo manejo é intenso, com o uso de grandes quantidades de agroquímicos - e serem de tamanho pequeno ( $<200$ ha) devem ter ocorrido extinções locais da espécie nesses remanescentes. A espécie também sofre com a invasão da lebre-européia (Lepus europaeus), que não foi detectada pelas armadilhas fotográficas durante o estudo, mas foi visualizada na área no final do período de campo (junho de 2006) e também encontrada nas análises de dieta em fezes de onça-parda (capitulo 2).

Também a cotia (Dasyprocta azarae) obteve uma relação positiva com o cerradão e não foi encontrada na floresta semidecídua ou nas áreas de plantio de eucaliptos. Segundo Mourão (2003), essa espécie é encontrada tanto em áreas mais abertas, como o cerrado sensu stricto, como em áreas florestais, como o cerradão e a floresta semidecídua. Novamente, a baixa qualidade dos fragmentos de floresta semidecídua amostrados pode ter sido responsável pela ausência de registros nessa fisionomia.

Os tatus do gênero Dasypus foram encontrados apenas no cerradão e no cerrado sensu stricto, o que provavelmente se deve ao fato de preferirem áreas de solo menos firme (arenoso) e não áreas com solo de origem basáltica para cavar, pois estes são mais resistentes à escavação (Carter \& Encarnação 1983).

A ocorrência da onça-parda (Puma concolor) em todas as fitofisionomias amostradas demonstra o caráter generalista desta espécie. A relação positiva entre a espécie e os plantios de eucaliptos provavelmente se dá pela grande necessidade de deslocamento de $P$. concolor que, por ser um grande carnívoro de topo de cadeia alimentar, precisa forragear em grandes áreas para 
encontrar recursos suficientes. Como a maioria dos fragmentos na área de estudo está envolta por essas monoculturas, a espécie a utiliza no deslocamento entre as áreas naturais remanescentes.

O lobo-guará (Chrysocyon brachyurus) não mostrou preferência por nenhuma das fisionomias amostradas, mas as altas correlações encontradas entre essa espécie e fragmentos com grandes áreas e perímetros de pastagem adjacentes reafirma a preferência da espécie por áreas mais abertas. Da mesma forma que a onça-parda, o lobo-guará também necessita forragear em áreas grandes, utilizando os plantios de eucaliptos para se deslocar pela paisagem.

O fato do tamanduá-bandeira (Myrmecophaga tridactyla) ter sido encontrado apenas no cerrado sensu stricto pode estar ligado ao fato de seu único recurso alimentar, os cupins e formigas, preferirem áreas mais abertas que as florestais (Medri \& Mourão 2005).

O gato-mourisco (Puma yagaouround $l$ ) foi registrado apenas nos plantios de eucaliptos. Isso ressalta seu comportamento críptico nas áreas naturais e sua plasticidade em utilizar habitats não naturais para se deslocar entre os remanescentes. Esse fato ainda não é muito conhecido na literatura científica e há pouco tempo atrás se achava que a espécie era extremamente sensível às alterações antrópicas (Cáceres et al. 2007).

O uso dos plantios de eucaliptos por diversas espécies, principalmente as cursoriais, indica a importância de um manejo florestal que garanta maior segurança aos indivíduos - por exemplo: cortes intercalados de talhões, de forma a não deixar a área totalmente exposta durante a época de corte, proteção contra caçadores e manutenção do sub-bosque, tornando o ambiente menos contrastante com as áreas naturais circundantes.

Neste estudo, infelizmente não foi possível amostrar as culturas de cana-de-açúcar, devido à alta intensidade no manejo da monocultura, à alta probabilidade de roubo das armadilhas (por ser um ambiente mais exposto à presença do homem) e às altas temperaturas diurnas nesse ambiente, que acabariam por prejudicar o bom funcionamento das armadilhas fotográficas. É possível que todas as espécies que utilizam as plantações de eucalipto utilizem as áreas de canade-açúcar também, pois muitas pegadas foram encontradas nessas áreas. A certeza é de que as monoculturas de cana-de-açúcar são muito mais impactantes aos remanescentes florestais e às espécies de mamíferos de médio e grande porte, tanto pelo tipo de seu manejo (muito mais intenso que o manejo dos eucaliptais: enquanto que as árvores de eucalipto são cortadas a cada 7 
anos, as monoculturas de cana-de-açúcar passam pelo processo de colheita a cada 7 meses, aproximadamente) como por seu contraste com as fitofisionomias vegetais presentes na área que são na sua maioria florestais, assim como o plantio de eucaliptos.

Ao se tentar entender as relações entre espécies de mamíferos de médio e grande porte e a configuração e composição das unidades que compõem uma determinada paisagem, surgem duas grandes questões metodológicas: a dificuldade na captura de indivíduos e a dificuldade em garantir a independência dos dados.

A dificuldade na captura de indivíduos praticamente impede o uso de metodologias de captura-e-recaptura, inviabilizando a determinação de estimativas de densidade das espécies. A maioria dos estudos envolvendo captura de mamíferos de médio e grande porte valeu-se da rádiotelemetria para a obtenção dos dados (Mantovani 2001). Esse método quase sempre envolve um número muito pequeno de indivíduos capturados, impedindo análises demográficas. Espécies com padrões de manchas na pelagem, como a jaguatirica e a onça-pintada, podem ser individualizadas por meio de armadilhamento fotográfico, pois suas manchas possuem as mesmas características de uma impressão digital. E essa pode ser uma alternativa metodológica para essas espécies.

A dificuldade em garantir a independência dos dados se dá pelo fato da maioria dos mamíferos de médio e grande porte possuírem uma grande capacidade de deslocamento em relação a outros grupos, fazendo com que os dados coletados muitas vezes se traduzam em pseudo-réplicas (Hargrove \& Pickering 1992). Segundo Hurlbert (1984), "garantir que as réplicas das medidas ou amostras que estão dispersas no espaço (ou tempo), de uma maneira apropriada para testar sua hipótese específica, é o aspecto mais critico do delineamento de um experimento".

Devido a esses problemas, uma outra alternativa para se explorar os fatores influentes na persistência das espécies de mamíferos de médio e grande porte pode ser correlacionando-se a freqüência da espécies com métricas de paisagem. Por exemplo, neste estudo, os coeficientes de correlação obtidos para Chrysocyon brachyurus indicaram que a espécie usa como habitat tanto os grandes fragmentos (Área; PARA) como as áreas abertas, como as pastagens (PasP; PasA). Essa correlação positiva com as áreas de pastagem pode se explicada pelo fato de $C$. brachyurus se alimentar de pequenos roedores, lagartos e tatus, animais mais facilmente capturados em áreas abertas. Por outro lado, a alta plasticidade e a capacidade de deslocamento em áreas alteradas da 
onça-parda (Puma concolor) e do gambá-de-orelha-branca (Didelphis albiventris) devem ser as razões para não se ter encontrado correlação destas espécies com nenhuma métrica avaliada.

O tamanduá-bandeira (Myrmecophaga tridactyla), anteriormente considerado uma espécie vulnerável, hoje teve sua categoria mudada para "próximo a ameaçado" (NT) pela lista vermelha da IUCN (IUCN 2006). Os resultados encontrados aqui mostram que a espécie não obteve correlação com nenhum índice e isso pode indicar um comportamento plástico semelhante ao de P. concolor.

A jaguatirica (Leopardus pardalis) e o veado catingueiro (Mazama guazoubira) preferem fragmentos menos isolados e o cateto (Pecari tajacu) está fortemente correlacionado à distância entre fragmentos de mesma cobertura vegetal, o que provavelmente também indica uma limitação de deslocamento na matriz.

Considerando as correlações aqui obtidas e a biologia das espécies estudadas, em uma escala grosseira, podemos distinguir três tipos de grupos funcionais de médios e grandes mamíferos em relação à paisagem:

a) Sensíveis à conectividade: não sobrevivem em áreas com fragmentos muito pequenos, com forte efeito de borda, mas poderiam sobreviver numa área com fragmentos médios, conectados por corredores largos. Possuem pequenas áreas de vida (em média $4 \mathrm{~km}^{2}$ ) - por exemplo: tapiti (Sy/vilagus brasiliensis).

b) Sensíveis à área de habitat: grandes mamíferos cursoriais, que não possuem muitas limitações em atravessar matrizes antrópicas, chegando até a transitar próximo a zonas urbanizadas. Possuem uma alta pressão de caça. Como a persistência de suas populações está muito ligada aos recursos, necessitam de várias áreas (fragmentos) para forragear. Possuem grandes áreas de vida $\left(50-230 \mathrm{~km}^{2}\right)$. Em longo prazo, têm seus recursos diminuídos, aumentando a competição direta por território - por exemplo: onça-parda (Puma concolor) e lobo-guará (Chrysocyon brachyurus).

c) Sensíveis à qualidade dos fragmentos e à conectividade do habitat: são sensíveis aos dois fatores, mas em menor grau que os primeiros ( $a$ e b). Precisam de fragmentos de boa qualidade (baixa influência humana), são afetados indiretamente pelos efeitos de borda, pois têm dieta específica e suas presas sofrem ação direta dos efeitos, resultando no declínio de suas 
populações, nestas áreas de borda. Suas áreas de vida são intermediárias em relação aos acima descritos $\left(15-20 \mathrm{~km}^{2}\right)$. Atravessam matrizes não muito contrastantes com o habitat, quando muito pressionados a encontrar recursos (tanto alimentares como reprodutivos) - por exemplo: jaguatirica (Leopardus pardalis). 


\subsection{Bibliografia}

ALHO, C.J.R., PEREIRA, L.A. \& PAULA, A.C. 1986. Patterns of habitat utilization by small mammal populations in cerrado biome of central Brazil. Mammalia 50:447-460.

ANDERSON, R.P., LEW, D., \& PETERSON, A.T. 2003. Evaluating predictive models of species distributions: criteria for selecting optimal models. Ecological Modelling 162:211-232.

ANDRÉN, H. 1994. Effects of habitat fragmentation on birds and mammals in landscapes with differents proportions of suitable habitat: a review. Oikos 71, 355-66.

BARLOW, J., OVERAL, W.L., ARAUJO, I.S., GARDNER, T.A. \& PERES, C.A. 2007. The value of primary, secondary and plantation forests for fruit-feeding butterflies in the Brazilian Amazon. Journal of Applied Ecology, 44:1001-1012.

BEIER, P. \& NOSS R. F. 1998. Do habitats corridors provide connectivity? Conservation Biology Vol.12 No. 6:1241-1252.

BYERS, C.R. \& STEINHORST, R.K. 1984. Clarification of a technique for analysis of utilization availability data. Journal of Wildlife Management. 48: 1050-1053.

BIERREGAARD, R.O. 1992. The biological dynamics of tropical rainforest fragments. Bioscience 42: 859-866.

BIOTA/FAPESP. 2007. DIRETRIZES PARA CONSERVAÇÃo E RESTAURAÇÃO DA BIODIVERSIDADE NO ESTADO DE SÃo PAULO. Imprensa Oficial do Estado. São Paulo. 236pp.

BURKEY, T.V. 1998. Extinction in nature reserves: the effects of fragmentation and the importance of migration between fragments. Oikos 55: 75-81.

CÁCERES, C., BORNSCHEIN, M.R., LOPES, W.H., PERCEQUILLO, A. R. 2007 Mammals of de Bodoqueira mountains southwestern Brazil: na ecologycal and conservation analysis Revista Brasileira de Zoologia 24 (2): 426-435.

CAVASSAN, O. 2002. O cerrado de estado de São Paulo. IN: KLEIN, A.L. Eugen Warming e o cerrado brasileiro: um século depois. Editora UNESP, FAPESP. Imprensa Oficial do Estado. São Paulo. 156pp. 
CARROLL, C.R. \& MEFFE, G.K. 1997. Management to meet conservation goals: General principles. In Principles of conservation biology (G.K. Meffe \& C.R. Carroll, orgs.). Sinauer Associates, Sunderland, p.347-384.

CARTER, T. S. \& ENCARNAÇÃO, C.D. (1983). Characteristics and use of burrows by four species of armadillos in Brazil. Journal of Mammalogy. 64:103-108.

CASTELLÓN, T. D. \& SIEVING, K.E.. 2006. An experimental test of matrix permeability and corridor use by an endemic understory bird. Conservation Biology 20:135-145.

COLWELL, R.K. 2004. estimates: Statistical Estimation of Species Richness and Shared Species from Samples, Version 7.5. Disponível em: http://viceroy.eeb.uconn.edu/estimates.

CONOVER, W.J. 1980. Practical Nonparametric Statistics, 2nd edn. John Wiley and Sons Inc., New York, NY.

CI. 2005. The new hotspots. Conservation International, Washington, D.C. Disponível em: http://www.conservation.org (ultimo acesso em dezembro de 2007).

DAILY, G., CEBALLOS, G., PACHECO, G., SUZAN, G., \& SANCHEZ-AZOFEIFA, A., 2003. Countryside biogeography of Neotropical mammals: Conservation opportunities in agricultural landscapes of Costa Rica, Biological Conservation 17(6):1814-1826

EITEN, G. 1972. The Cerrado vegetation of Brazil. Botanical Review. 38: 205-341.

FARIA, D.R., LAPS, R., BAUMGARTEN, J., CETRA, M. 2006. Bat and bird assemblages from forests and shade cacao plantations in two contrasting landscapes in the Atlantic Forest of southern Bahia, Brazil. Biodiversity Conservation 15: 587-612

FLEISHMAN, E., NOSS, R.F. \& NOON, B.R. 2006. Utility and limitations of species richness metrics for conservation planning. Ecological Indicators, 6, 543-553.

FAHRIG, L. 1998. When does fragmentation of breeding habitat affect population survival? Ecological Modeling 105: 273-92

FAHRIG, L. 2003. Effects of habitat fragmentation on biodiversity. Annu. Rev. Ecol. Evol. Syst. $34: 487-515$. 
FONSECA, G.A.B. \& K.H. REDFORD. 1984. The mammals of IBGE's ecological reserve, Brasília, and an analysis of the role of gallery forests in increasing diversity. Revista Brasileira de Biologia, Rio de Janeiro, 44 (4): 517-523.

GASCON, C., LOVEJOY, T.E., BIERREGAARD, R.O., MALCOM J.R., STOUFFER P.C., H. VASCONCELOS, W. F. LAURENCE, B. ZIMMERMAN, M. TOHER, and S. BORGES. 1999. Matrix habitat and species persistence in tropical forest remnants. Biological Conservation 91:223-229.

GODWIN, B. J. \& FAHRIG L. 2002. How does landscape structure influence landscape connectivity? Oikos 99:552-570.

HADDAD, N.M., BOWNE, D.R., CUNNINGHAM, A., DANIELSON, B.J., LEVEY, D.J., SARGENT, S. \& SPIRA, T. 2003. Corridor use by diverse taxa. Ecology, 84:609- 615.

HANSKI, I. 2004. Metapopulation theory, its use and misuse. Basic and Applied Ecology 5:225229.

HARGROVE, W. W., \& PICKERING, J. 1992. Pseudoreplication: A sine quanon for regional ecology. Landscape Ecology 6:251-258.

Hulbert, S.H. 1984. Pseudoreplication and the design of ecological field experiments. Ecological Monographs 54:187-211.

HUTCHINSON, G. E., 1959, Homage to Santa Rosalia or Why are there so many kinds of animals? American Naturalist, 93:145-159.

KOVACH, W.L. 2004. Multivariate Statistical Package. Version 3.1 for Windows.

JÁCOMO, A. T. A. 1999. Nicho alimentar do lobo-guará (Chrysocyon brachyurus Illiger, 1811) no Parque Nacional das Emas - GO. Dissertação (Mestrado), Universidade Federal de Goiás, Goiania, Brasil. 104 pp.

KAPOS, V. 1989. Effects of isolation on the water status of forest patches in the Brazilian Amazon. Journal of Tropical Ecology 5: 173-185.

KARANTH, K. U. 1995. Estimating tiger Panthera tigris populations from camera-trap data using capture-recapture models. Biological Conservation. 71: 333-338. 
KRONKA, F.J.N., MATSUKUMA, C.K., NALON, N.A., CALI, I.H.D., ROSSI, M., MATTOS, I.F.A., SHIN

- IKE, M.S.\& PONTINHA, A.A.S. 1993. Inventário florestal do estado de São Paulo. SMA / CINP / Instituto Florestal.

LAMBECK, R. J. 1997. Focal species: a multi-species umbrella for nature conservation. Conservation Biology 11: 849- 856.

LAURENCE, W.F. 1991. Ecological correlates of extinction proneness in Australian tropical rain forest mammals. Conservation Biology. 5: 79-89.

LYRA-JORGE, M.C. 1999. Avaliação do potencial faunístico da A.R.I.E. Cerrado Pé-deGigante (Parque Estadual do Vassununga, Santa Rita do Passa Quatro - SP) com base na análise de habitats. Dissertação (Mestrado). Instituto de Biociências, Universidade de São Paulo.São Paulo, SP, Brazil.

LYRA-JORGE, M. C. 2007. Avaliação de qualidade de fragmentos de cerradão e floreta semidecídua na região do rio Mogi-Guaçú com base na ocorrência de carnívoros. Tese (Doutorado) - Departamento de Ecologia - Instituto de Biociências - Universidade de São Paulo (USP). São Paulo. 125pp

MCGARIGAL, K., CUSHMAN, S. A., NEEL, M. C. \& ENE, E. 2002. FRAGSTATS: Spatial Pattern Analysis Program for Categorical Maps. Computer software program produced by the authors at the University of Massachusetts, Amherst. Disponível em: www.umass.edu/landeco/research/fragstats/fragstats.html

MANTOVANI, J.E. 2001. Telemetria convencional e via satélite na determinação da área de vida de três espécies de carnívoros da região nordeste do estado de São Paulo. Tese de doutorado. Universidade de São Carlos. São Carlos, SP.

MEDRI, Í.M. \& MOURÃO, G. 2005. Home range of giant anteaters (Myrmecophaga tridactyla) in the Pantanal wetland, Brazil. Journal of Zoology. (Lond.) 266:365-375.

METZGER, J.P. 2000. Tree functional group richness and landscape structure in a Brazilian tropical fragmented landscape. Ecological Applications 10: 1147-1161.

METZGER, J.P. 2006. Como lidar com regras pouco óbvias para conservação da biodiversidade em paisagens fragmentadas. Natureza \& Conservação - vol. 4 - 2:11-23. 
NIMER, E.. Climatologia do Brasil. Rio de Janeiro: IBGE, 1977.

NORMAN, G.R.; STREINER, D.L. Biostatistics - The base essential. St. Louis: MosbyYearBook, 1994. 260p.

NOSS, R.F. 1985 A regional approach to maintain diversity. BioSciense vol. 22 n.11: 700-706.

PAESE, A. 2002.. A utilização de modelos para a análise da paisagem na região nordeste do estado de São Paulo. Tese (Doutorado). Universidade Federal de São Carlos, São Carlos. 153 pp.

PIRES, J.S.R. 1995. Análise ambiental voltada ao planejamento e gerenciamento do ambiente rural: abordagem metodológica aplicada ao município de Luiz Antônio - SP. Tese (Doutorado) - Departamento de Hidrobiologia-Laboratório de Análises e Palnejamento Ambiental - Universidade Federal de São Carlos, São Carlos. 153 pp.

QUINN, J.F. \& HASTINGS, A. 1987. Extinction en subdivided habitats. Conservation Biology 3: 198-208.

RUGGiero, P.G.C.; BATALHA, M.A.; PIVELLO, V.R. \& MEIRELLES, S.T. 2002. Soil-vegetation relationships in cerrado (Brazilian savanna) and semideciduous forests, Southeastern Brazil. Plant Ecology, 160: 1-16.

SANTOS, A.J. 2003. Estimativas de riqueza em espécies. In Métodos de estudos em biologia da conservação e manejo da vida silvestre (L. Cullen Jr., R. Rudran \& C. ValladaresPádua, orgs.). UFPR, Curitiba, p.19-41

SCHONEWALD-COX, C.M. \& BUECHNER, M. 1992. Park protections and public roads. In P. L. Fielder e S. K. Jain (eds.), Conservation Biology: The Theory and Practice of Nature Conservation, Preservation, and Management. New York: Chapman and Hall.

SHAFER, C. L. 1990. Nature Reserves - Island Theory and Conservation Practice. Washington: Smithsonian Institution Press, 1990.

SHIDA, C.N. 2005. Caracterização física do cerrado Pé-de-Gigante e uso das terras na região. Evolução do uso das terras na região. In: PIVELLO, V.R.\& VARANDA, E. O Cerrado Pé-deGigante. Parque Estadual de Vassununga. Ecologia e Conservação. SEMA, São Paulo. 310pp. 
SILVEIRA, L., JÁCOMO, A. T. A. \& DINIZ-FILHO, A. F. 2003. Camera trap, line transect census and track surveys: a comparative evaluation. Biological Conservation 114:351-353.

SIMBERLOFF, D. 1992. Do species-area curves predict extinction in fragmented forest?. In: T.C. Whitmore and J.A. Sayer, Editors, Tropical Deforestation and Species Extinction. Chapman \& Hall, New York, pp. 75-90.

SMITH E.P. \& VAN BELLE G. 1984. Nonparametric estimation of species richness. Biometrics, 40:119-129.

SRBEK-ARAÚJO, A. C. \& CHIARELLO, A. G. 2007. Armadilhas fotográficas na amostragem de mamíferos: considerações metodológicas e comparação de equipamentos. Revista Brasileira de Zoologia 24 (3):647-656

TALAMONI, S.A.; MOTTA-JÚNIOR, J.C.; DIAS, M.M. 2000. Fauna de mamíferos da Estação Ecológica de Jataí e Estação Experimental de Luiz Antônio. 317-319pp. In Santos, J.E.; Pires, J.S.R. Estudos Integrados em Ecossistemas. Estação Ecológica de Jataí. RiMa Editora. São Carlos. 346p.

TAMBOSI, L. R. 2008. Análise da paisagem no entorno do Parque Estadual de Vassununga subsídios para a criação da zona de amortecimento. Dissertação (Mestrado). Departamento de Ecologia - Instituto de Biociências - Universidade de São Paulo (USP) 86pp.

TROLLE, M. \& KÉRY, M. 2005. Camera-trap study of ocelot and other secretive mammals in the northern Pantanal. Mammalia 69, 3-4.

WALTER, H. Vegetação de Zonas Climáticas, São Paulo: E.P.U 1983.

WIENS, J.A. 1995: Landscape mosaics and ecological theory. In Hansson, L., Fahrig, L. and Merriam, G., editors, Mosaic landscapes and ecological processes, London: Chapman \& Hall, 1-26.

WILCOVE, D.S. \& MAY, R.S. 1986. National park boundaries and ecological realities. Nature 324: 206-207. 


\section{Capítulo 2}

\section{DIETA E SOBREPOSIÇÃO DE NICHO DE ONÇA-}

PARDA (PUMA CONCOLOR), JAGUATIRICA (LEOPARDUS PARDALIS) E LOBO-GUARÁ

(CHRYSOCYON BRACHRYURUS) NUMA PAISAGEM FRAGMENTADA 


\subsection{Introdução:}

A atual degradação ambiental vem consumindo a área de todos os biomas mundiais (Conservação Internacional 2002). Segundo Begon (2006), existem 1.400 .000 espécies identificadas no mundo e o número estimado de espécies é de 10-100 milhões. A perda de diversidade é estimada por (Wilson 1993):

$$
S=c A^{z},
$$

onde S é a riqueza, A é a área e c e z constantes de extinção e colonização. Como se pode ver as extinções estão altamente relacionadas à perda de habitat, quanto menor for a área disponível para as espécies maior probabilidade de extinções locais regionais.

A perda de habitats leva, na maioria dos casos, a um processo denominado fragmentação (Metzger 2001). Esse processo isola estruturalmente remanescentes de vegetação natural gerando na paisagem, anteriormente contínua, um mosaico composto por diferentes ocupações das terras pelo homem e fragmentos de vegetação nativa. Nessas áreas, onde a vegetação natural encontrase com poucos fragmentos, e estes, com alto grau de isolamento, espera-se que as populações das espécies presentes também se apresentem isoladas e, portanto, com maior probabilidade de extinção local (Turner 2005). Esse isolamento pode levar à diminuição das densidades populacionais de espécies mais sensíveis, o que acarreta em um aumento da competição por recursos, por parte dos consumidores. Por outro lado, espécies generalistas podem obter vantagem nas perturbações geradas pela fragmentação, como os efeitos de borda (Downes \& Elgar 1997). Nestes casos, predadores oportunistas podem substituir, em sua dieta, espécies sensíveis, antes abundantes, por espécies generalistas que se tornam abundantes após a fragmentação.

O isolamento funcional dos fragmentos está diretamente relacionado à capacidade da espécie se movimentar em diversos tipos de matrizes antropogênicas e percorrer as distâncias entre os fragmentos. Por exemplo, quando dois fragmentos estão separados entre si por uma matriz de plantio de cana-de-açúcar e distam 400 metros um do outro, para uma espécie menos sensível, como a onça-parda (Beier 1995), pode-se dizer que os dois fragmentos estão 
funcionalmente conectados, pois a espécie pode se locomover entre os fragmentos sem dificuldades. Já para uma espécie mais sensível, como o gato-maracajá (Oliveira \& Cassaro 1999), a distância entre os fragmentos e o tipo de matriz não podem ser transpostos, o que acarreta em um isolamento funcional, além do estrutural, para esta espécie. Quanto mais próximos os fragmentos e quanto menor o contraste entre a matriz e a área natural, maior a probabilidade dos fragmentos estarem funcionalmente conectados para as diferentes espécies que ocorrerem na paisagem (Goodwin \& Fahrig 2002, Bélisle 2005).

O estudo da dieta de uma comunidade gera diversas informações, entre elas: relações ecológicas, fisiológicas e comportamentais, competição e suas conseqüências na forma e no tamanho dos nichos, plasticidade das espécies associada à disponibilidade de recursos, influência da sazonalidade sobre o nicho, capacidade de dispersão de sementes, aspectos gerais do controle populacional, da estrutura das comunidades e das estratégias de forrageamento (Roper 1994; Wright et al. 1994; Valkenburgh \& Wayne 1994, Jácomo 1999). Além disso, o conhecimento dos aspectos ecológicos da dieta pode auxiliar na elaboração de estratégias de manejo e conservação da fauna silvestre e seus respectivos habitats (Bisbal \& Ojasti, 1980).

Existem diversos métodos para análise da dieta: i) análise direta do conteúdo estomacal (Facure \& Monteiro Filho 1996); ii) análise de carcaças e encontradas nos campo e examinando o local em busca de indícios da espécie predadora (Crawshaw \& Quigley 1984); iii) observação direta dos indivíduos em comportamento natural de predação (Brady 1979) e iv) através da análise de fezes encontradas no campo (Motta-Junior et al. 1996). Em paisagens fragmentadas, com estradas de terra cortando as áreas naturais e antrópicas, e com condições de relevo e vegetação favoráveis, a análise das fezes é a metodologia mais apropriada para o estudo da dieta de várias espécies de carnívoros, que as utilizam para a demarcação de território, deixando-as em lugares bem visíveis, como as estradas de terra e as trilhas dentro dos fragmentos. Esse hábito permite a coleta abundante de material sem a utilização de métodos invasivos, como a análise de conteúdo estomacal, ou cansativos como a observação direta de predação no campo (Reynolds \& Aebischer 1991).

Neste capitulo, foi estudada a dieta de três carnívoros de topo de cadeia alimentar: a onça-parda (Puma concolor), a jaguatirica (Leopardus pardalis) e o lobo-guará (Chrysocyon 
brachyurus). Os objetivos visados com o estudo da dieta destes carnívoros foram: i) analisar a freqüência de utilização de diferentes itens alimentares pelas três espécies; ii) verificar o grau de sobreposição de nicho entre as espécies e iii) comparar a densidade de fezes encontradas dentro e fora das unidades de conservação existentes na área de estudo, para as três espécies.

\subsection{Materiais e métodos:}

\subsection{1. Área de estudo:}

A área de estudo está localizada entre as coordenadas $21^{\circ} 30^{\prime}-21^{\circ} 45^{\prime} \mathrm{S}$ e $47^{\circ} 20^{\prime}-47^{\circ}$ $55^{\prime} \mathrm{W}$, ocupando aproximadamente $500 \mathrm{Km}^{2}$. Caracteriza-se por ser uma região de transição entre cerrado e floresta semidecídua, no estado de São Paulo, abrangendo os municípios de Luiz Antonio e Santa Rita do Passa Quatro, e contém a Estação Ecológica de Jataí, a Estação Experimental de Luiz Antonio, o Parque Estadual de Vassununga, além de pequenos fragmentos de vegetação nativa localizados em áreas particulares. O clima é do tipo tropical savânico, onde a temperatura nos meses de inverno (estação seca) vai de 15 a $31^{\circ} \mathrm{C}$ e, nos meses mais quentes (estação úmida), de 20 a $36^{\circ} \mathrm{C}$ (Nimer 1977). A pluviosidade anual é geralmente superior a 1.400 mm, com período de precipitação mais intenso de outubro a março (Pires 1995).

O Parque Estadual de Vassununga, localizado em Santa Rita do Passa Quatro, possui área total de $2.069,24$ ha, dividido em seis glebas. A Gleba Pé-de-Gigante é a única composta por fisionomias de cerrado, desde campo cerrado até cerradão, e uma pequena área composta por floresta estacional semidecídua ela faz divisa com plantações de eucaliptos ao norte e oeste, com a rodovia Anhanguera a leste e com monoculturas de cana-de-açúcar ao sul. As demais glebas (Praxedes, Maravilha, Capetinga Leste, Capetinga Oeste e Capão Várzea) são cobertas por floresta estacional semidecídua (Korman 2003) apresentam tamanho pequeno, variando de 100 a 350 ha, todas estão imersas em uma matriz de plantação de cana-de-açúcar. A Estação Ecológica de Jataí e a Estação Experimental de Luiz Antonio localizam-se no município de Luiz Antonio. O remanescente de vegetação natural existente na Estação Ecológica de Jataí possui 
aproximadamente de 4.532 ha (Decreto-lei 18.997, de 15/06/1982) e é o maior fragmento existente no estado de São Paulo com área contínua de cerrado "sensu lato". Limita-se a oeste com o rio Mogi-Guaçu, abrangendo uma planície de inundação, onde existem 15 lagoas. As formações vegetais são bastante diversificadas, encontrando-se floresta semidecídua, florestas ripárias, cerrado em diversas fisionomias, desde campo sujo a cerradão (Toppa 2004). 


\subsubsection{Carnívoros estudados:}

\section{O Lobo-guará (Chrysocyon brachyurus, Illiger 1815):}

É o maior canídeo sul-americano (figura 1) podendo chegar a $40 \mathrm{~kg}$, com peso médio de $26 \mathrm{~kg}$. Mede de 145 a $190 \mathrm{~cm}$ de comprimento e $80 \mathrm{~cm}$ de altura (Motta-Junior. et al. 1996, Santos 1999). Habita toda a região compreendida pelo Planalto Central, Pantanal Matogrossense, extremo sul da bacia Amazônica, área que se estende para o leste até o limite com as áreas de Floresta Atlântica dos estados da Bahia, Minas Gerais, São Paulo, e parte semi-árida da região nordeste, até o extremo sul do país (Paraná). Os indivíduos são solitários durante o ano todo, a não ser no período de acasalamento, quando formam pares. Podem ter de dois a cinco filhotes, que atingem a maturidade com um ano de vida (Dietz 1985).

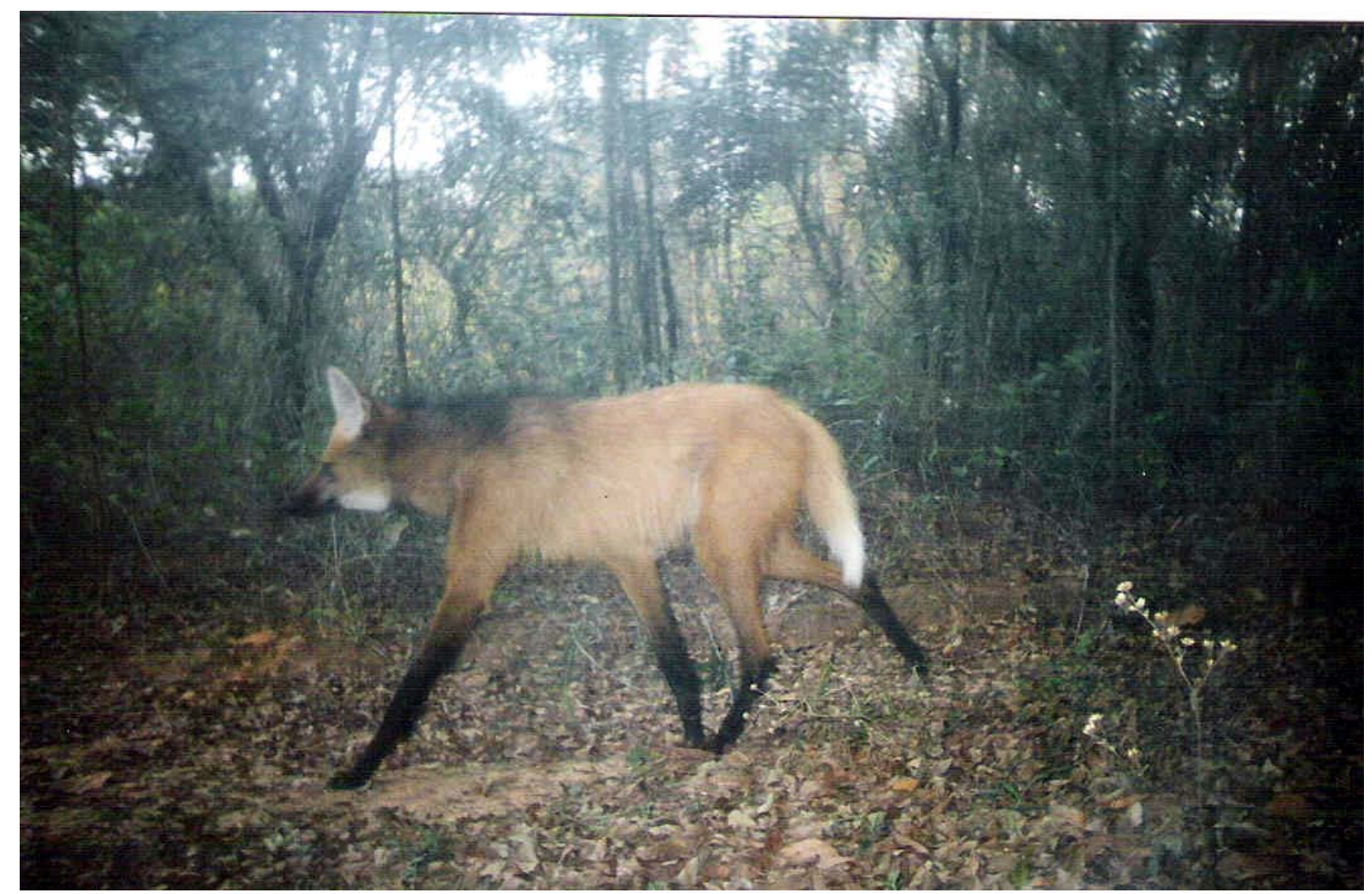

Figura 2. Fotografia de lobo-guará (Chrysocyon brachyurus) obtida por meio de armadilhamento fotográfico, na área de estudo. 


\section{A Onça-parda (Puma concolor, Linnaeus 1771):}

É o segundo maior felino americano (figura2), perdendo apenas para a onça-pintada, Panthera onça. Chega a atingir 1,08 m de comprimento, mais a cauda, que é longa, medindo até $61 \mathrm{~cm}$; pode chegar a $63 \mathrm{~cm}$ de altura e pesar até $80 \mathrm{~kg}$. Solitários, só formam pares para a corte. Podem ter de um a seis filhotes a cada dois anos. A espécie é encontrada na América do Norte, América do Sul e América Central. No Brasil, pode ocorrer em todos os biomas (Oliveira \& Cassaro 1999).

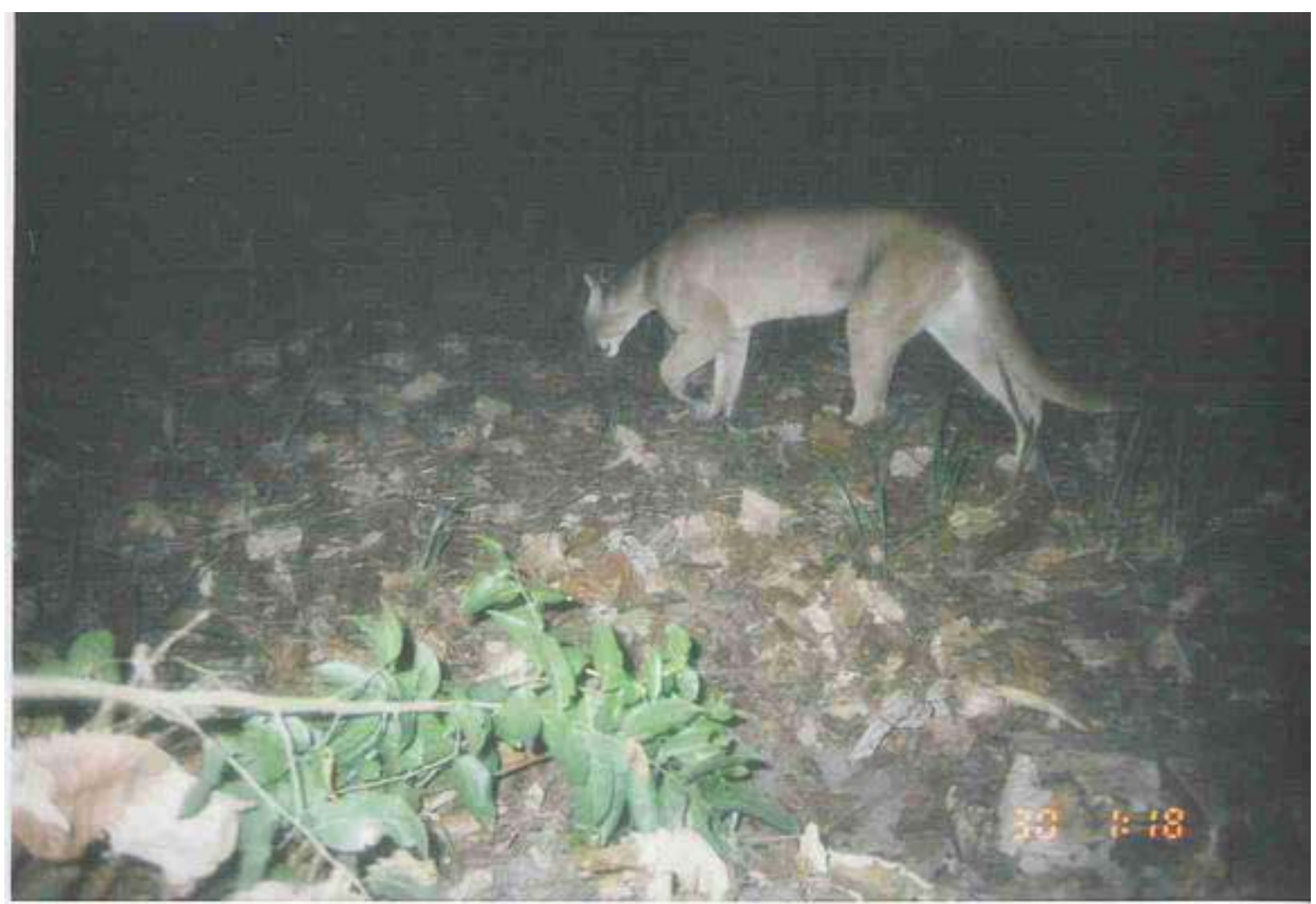

Figura 3. Fotografia de onça-parda (Puma concolor) obtida por meio de armadilhamento fotográfico, na área de estudo. 


\section{A Jaguatirica (Leopardus pardalis, Linnaeus 1778):}

É um felino de médio porte (figura 3) e mede entre $65 \mathrm{~cm}$ a um metro de comprimento, excetuando-se a cauda, que pode chegar a $45 \mathrm{~cm}$. Pesa entre 8 e $16 \mathrm{~kg}$. De hábitos noturnos, passa a maior parte do dia dormindo nos galhos das árvores ou escondido entre a vegetação. As fêmeas têm de um a quatro filhotes. O período de gestação varia de 70 a 95 dias. As fêmeas chegam à idade adulta em um ano e meio e os machos aos dois anos (Oliveira \& Cassaro 1999). Atualmente, a espécie se distribui do sul do Texas ao norte da Argentina e Uruguai. (Audubon \& Bachman 1846).

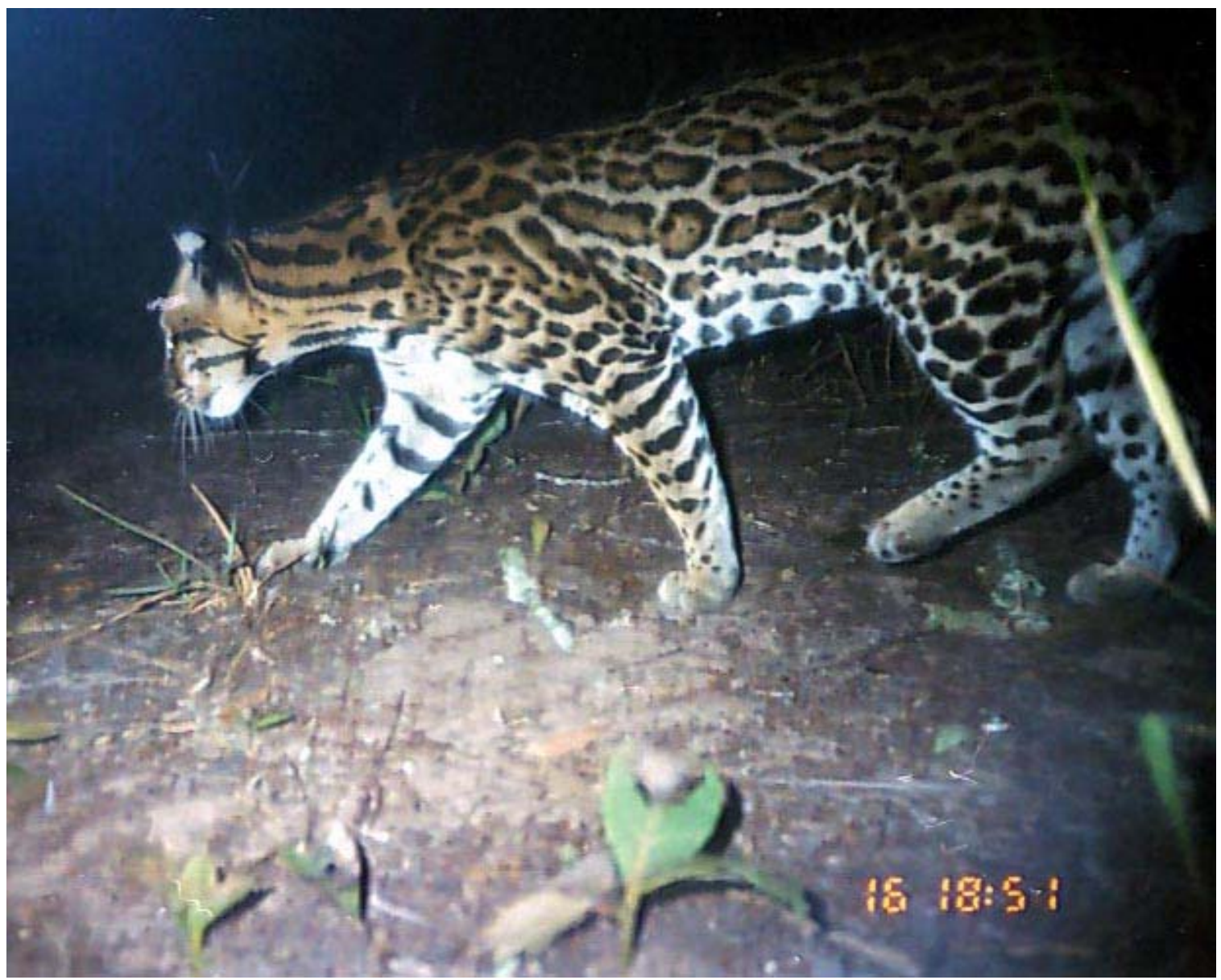

Figura 4. Fotografia de jaguatirica (Leopardus pardalis) obtida por meio de armadilhamento fotográfico, na área de estudo. 


\subsubsection{Coleta e triagem das fezes:}

Foram percorridas estradas de terra existentes na região e que se sabia serem utilizadas pelas espécies para deslocamento entre as áreas. Em cada área, a quilometragem percorrida durante a procura das fezes foi anotada, a fim de se estimar e comparar a densidade de fezes. As fezes coletadas foram armazenadas em sacos plásticos, tendo sido identificadas com uma ficha de coleta (Tabela 1) contendo dados significativos para a identificação do predador e outras análises.

Tabela 1 Ficha de coleta de fezes dos carnívoros estudados, elaborada para as coletas neste trabalho.

Data da Coleta: Número da amostra

Posição na estrada: $\quad$ Tipo de substrato:

Idade estimada: Condição estrutural:

Posição do GPS: $\quad$ Cobertura e uso do solo:

Rastros indicativos: $\quad$ Espécie provável:

Após a coleta, as fezes foram armazenadas em solução conservadora ( $5 \%$ de formol a $10 \%, 91 \%$ de álcool $70^{\circ} \mathrm{gl}, 4 \%$ de ácido acético e algumas gotas de detergente comercial) para posterior triagem. Essa solução, além de conservar as fezes por um longo período, elimina todos os microorganismos patogênicos (Mantovani 2001).

A triagem consistiu na lavagem das fezes em água corrente e na separação dos itens alimentares em oito categorias: dentes, ossos, pêlos, penas, partes de insetos, partes de frutas, escamas e material inorgânico (Putman 1984). Para a identificação dos itens, foi usada uma 
coleção de referência montada durante o estudo (composta de frutas, folhas, e animais mortos coletados na área de estudo), coleções (Museu de História Natural da Universidade de São Paulo, coleção do Professor Doutor Manuel Martins Fontes da Universidade Federal de São Carlos e coleta direta de pelos de mamíferos existentes no Parque Ecológico de São Carlos) e a análise microscópica dos pêlos, segundo a técnica descrita por Quadros (2002). As chaves de classificação, baseadas nas características de medula e cutícula dos pelos (descritas em Quadros 2002), foram utilizadas para identificar aqueles que não puderam ser identificados apenas por comparação.

A técnica de análise da cutícula dos pêlos-guarda consiste em (Quadros, 2002):

1- retirar os pêlos encontrados tanto em campo quanto nas fezes;

2- separar os pêlos-guarda, com bulbo e ápice;

3- lavar os pêlos-guarda em álcool comercial e secá-los em papel absorvente;

4- cobrir uma lâmina de vidro com uma fina camada de esmalte incolor para unhas, deixando-a secar por 15-20min;

5- colocar os pêlos-guarda sobre o esmalte;

6- colocar a lâmina contendo os pêlos sobre um pedaço de madeira e cobrir com outro pedaço de madeira revestida com fita adesiva transparente;

7- pressionar o conjunto com uma morsa ou uma prensa de braços retangulares;

8- abrir a morsa e separar a lâmina com os pêlos do resto do conjunto;

9- deixar o esmalte secar totalmente por mais 30 minutos;

10- retirar os pêlos pela parte distal esfregando suavemente com a ponta do dedo;

11- armazenar as lâminas de impressões cuticulares para futura análise em local protegido de poeira e umidade.

A técnica para análise da medula dos pêlos guarda consiste em (Quadros, 2002): 
1- colocar os pêlos-guarda (podem ser os mesmos utilizados na impressão cuticular) em água oxigenada cremosa 30 volumes, comercial, de uso cosmético por 80 minutos;

2- lavar os pêlos em água e secá-los em papel absorvente;

3- montar as lâminas permanentes, com meio de montagem sintético transparente e lamínula; ou lâminas temporárias, com água, glicerina e lamínula.

As características da cutícula e da medula foram utilizadas em conjunto para a determinação das espécies encontradas nas fezes de lobo-guará, da onça-parda e da jaguatirica.

\subsubsection{Análises dos dados}

\subsubsection{Descrição da dieta das espécies}

Para evitar que presas fossem registradas mais de uma vez, o número mínimo dos itens foi obtido por meio do número de estruturas anatômicas, simples ou duplas, como crânios, mandíbulas, maxilares, bicos, alguns tipos de dentes e partes cefálicas de insetos (Lockie 1959, Jaksic et al. 1993, Pavez et al. 1992).

Para calcular a porcentagem de ocorrência dos itens encontrados nas fezes, foi utilizada a seguinte fórmula (Dietz 1984, Garla \& Setz 2001):

$\% \mathrm{Oi}=\mathrm{ni} \times 100 / \mathrm{Ni}$,

onde \%Oi é a porcentagem de ocorrência do item i em relação a todos os itens encontrados, ni é o número de vezes que o item em questão aparece nas fezes e Ni é o número total de itens encontrados.

Para calcular a porcentagem de fezes com determinado item foi utilizada a seguinte fórmula (Chinchilla 1997, Servín \& Huxley 1991): 
$\% O f i=$ nfi $\times 100 /$ Nf,

onde \%Ofi é a porcentagem de fezes com o item i em relação a todas as fezes encontradas, nfi é o número de fezes com o item i e Nf é o número total de fezes encontradas.

Foram separadas as fezes coletadas na estação seca das coletadas na estação chuvosa. A porcentagem das classes de itens encontradas nas fezes em cada estação foi calculada, e um teste de qui-quadrado foi realizado para verificar se houve diferença significativa na variação das dietas nas diferentes estações.

\subsubsection{Comparação das dietas das espécies}

\section{Amplitude de Nicho}

Foi utilizado o índice de Levins (Pianka 1973) para avaliar a amplitude de nicho:

$B_{A}=(B-1) /(n-1)$,

onde $\mathrm{B}_{\mathrm{A}}$ é o índice padronizado de Levins, $\mathrm{n}$ representa o total de itens e $\mathrm{B}$ o índice de Levins: $\mathbf{B}=$ $1 / \Sigma \mathbf{p}_{\mathrm{ij}}{ }^{2}$. Onde $\mathrm{p}_{\mathrm{ij}}$ é a freqüência do item i na dieta da espécie j. B é calculado unindo itens em categorias: mamíferos de pequeno porte, mamíferos de médio porte, mamíferos de grande porte, aves de médio porte, aves de pequeno porte, répteis, insetos, frutos e capim. 


\section{Sobreposição de Nicho}

Foi utilizado o índice de Pianka (1974) para avaliar a sobreposição de nicho

$$
O_{j k}=O_{k j}=\frac{\sum_{i}^{n} p_{i j} p_{i k}}{\sqrt{\sum_{i}^{n} p_{i j}^{2}{ }_{i}^{n} p_{i k}{ }^{2}}}
$$

onde $p_{i}$ é a freqüência do item i na amostra, e Ojk é a sobreposição de nichos entre as espécies j e k. Os resultados de 0 variam de 0 a 1 ; valores próximos a 0 indicam pouca sobreposição. A sobreposição de nicho será calculada para cada par de espécies. A sobreposição de nicho foi calculada utilizando-se as classes de tamanho e grupo: 1$)$ mamíferos de pequeno porte $(0-500 \mathrm{~g})$; 2) mamíferos de médio porte (501-10000g); 3) mamíferos de grande porte (> 1000g); 4) répteis; 5) aves de médio porte $(51-1500 \mathrm{~g}) ; 6)$ aves de pequeno porte $(0-50 \mathrm{~g})$; 7) insetos; 8) frutos e 9) capim.

\subsubsection{Abundância das fezes dos carnívoros encontradas no campo em relação à quantidade de quilômetros percorrida.}

A área de estudo foi dividida em três sub-áreas: a primeira envolve os fragmentos pertencentes à Estação Ecológica e Experimental de Luiz Antonio (EELA), a segunda são fragmentos pertencentes à propriedades privadas e a terceira são glebas do Parque Estadual de Vassununga (PEV). Em cada uma delas, foram percorridas estradas de terra com indícios de passagens das espécies em estudo. O número de fezes de uma determinada espécie, encontradas no campo, foi dividido pelo total de quilômetros percorridos, em cada uma das três áreas, na procura por fezes. O resultado reflete a abundância relativa de cada uma das espécies nas diferentes sub-áreas (Wilson \& Delahay 2001). 


\subsection{Resultados}

Foram coletadas e identificadas 233 amostras de fezes, sendo 93 de lobo-guará (Chrysocyon brachyurus), 68 de onça-parda (Puma concolor), 38 de jaguatirica (Leopardus pardalis), 30 de outros pequenos felinos (Leopardus wiedii, Leopardus tigrinus e Puma yagoaouroundl) e 4 de cachorro-do-mato (Cerdocyon thous). Para realizar algumas das análises, os itens alimentares foram agrupados em nove classes: mamíferos de pequeno porte $(0-500 \mathrm{~g})$, mamíferos de médio porte (501-10000g), mamíferos de grande porte (> 1000g), répteis, aves de médio porte (51-1500g), aves de pequeno porte $(0-50 \mathrm{~g})$, insetos, frutos e capim. Nas fezes do lobo-guará, todas as classes menos mamíferos de grande porte, foram encontradas; já nas fezes de jaguatirica, apenas cinco classes foram encontradas, sendo elas: mamíferos de pequeno porte, mamíferos de médio porte, répteis, aves de médio porte e capim. Nas fezes da onça-parda, foram encontradas quatro das classes, sendo elas: mamíferos de grande porte, mamíferos de médio porte, aves de médio porte e répteis.

\subsubsection{Dieta do Lobo-guará (Chrysocyon brachyurus)}

Dos 22 itens identificados nas fezes do lobo-guará, 5 eram de origem vegetal e 16 de origem animal, sendo 9 de mamíferos, 2 de répteis, 2 de aves e 3 de artrópodes . Os itens mais expressivos foram: roedores de pequeno porte, correspondendo a $21,81 \%$ dos itens e encontrados em $75 \%$ das fezes, e a lobeira (Solanum lycocarpum), correspondendo a $16.91 \%$ dos itens e aparecendo em $71,88 \%$ das fezes (tabela 2). A seguir, vieram tatus do gênero Dasypus $(11,03 \%)$, partes de Orthoptera $(8,33 \%)$ e marsupiais de pequeno porte $(6,86 \%)$. 
Tabela 2. Porcentagens dos itens encontrados nas fezes ( $\mathrm{Oi}=$ quantidade de vezes que o item aparece em relação a todos os itens) e de fezes com o item encontrado (Ofi = quantidade de vezes que o item aparece em relação ao total de fezes encontradas) para o lobo-guará (Chrysocyon brachyurus) na área de estudo. $(\mathrm{N}=$ total de fezes; $\mathrm{nfi}=$ número de fezes com o item $\mathrm{i}$; $\mathrm{ni}=$ número de itens i encontrado nas fezes; $\mathrm{pp}=$ pequeno porte; $\mathrm{mp}=$ médio porte).

\begin{tabular}{|c|c|c|c|c|c|}
\hline $\mathrm{N}=93$ & & nfi & ni & Ofi (\%) & Oi (\%) \\
\hline & Marmosops incanus & 3 & 3 & 3,13 & 0,74 \\
\hline Mamíferos de & Roedor pp & 72 & 89 & 75,00 & 21,81 \\
\hline \multirow[t]{3}{*}{ pequeno porte } & Marsupial pp & 21 & 28 & 21,88 & 6,86 \\
\hline & Mamífero pp & 12 & 12 & 12,50 & 2,94 \\
\hline & Mamífero mp & 5 & 5 & 5,21 & 1,23 \\
\hline Mamíferos de & Dasypus sp & 45 & 45 & 46,88 & 11,03 \\
\hline \multirow[t]{2}{*}{ médio porte } & Monodelphis sp & 1 & 1 & 1,04 & 0,25 \\
\hline & Tamandua tetradactila & 5 & 5 & 5,21 & 1,23 \\
\hline \multirow{5}{*}{ Répteis } & Serpente & 15 & 15 & 15,63 & 3,68 \\
\hline & Tupinambis teguxim & 13 & 13 & 13,54 & 3,19 \\
\hline & Ave mp & 7 & 7 & 7,29 & 1,72 \\
\hline & Ave pp & 18 & 18 & 18,75 & 4,41 \\
\hline & Scarabaeidea & 6 & 13 & 6,25 & 3,19 \\
\hline \multirow{4}{*}{ Insetos } & Cerambycidae & 7 & 9 & 7,29 & 2,21 \\
\hline & Orthoptera & 15 & 34 & 15,63 & 8,33 \\
\hline & Solanum lycocarpum & 69 & 69 & 71,88 & 16,91 \\
\hline & Citrus sp. & 12 & 12 & 12,50 & 2,94 \\
\hline \multirow[t]{5}{*}{ Frutos } & Annona coriacea & 7 & 7 & 7,29 & 1,72 \\
\hline & Semente não identificada & 1 & 1 & 1,04 & 0,25 \\
\hline & Semente não identificada 1 & 1 & 1 & 1,04 & 0,25 \\
\hline & Capim & 21 & 21 & 21,88 & 5,15 \\
\hline & TOTAL & - & 408 & 8 & 100,00 \\
\hline
\end{tabular}

Em relação à sazonalidade, verificou-se que o lobo-guará consumiu maior quantidade de mamíferos e aves de pequeno porte durante a estação seca. Houve um maior consumo de répteis e frutos durante a estação chuvosa, as aves de médio porte e os insetos só foram consumidos na estação chuvosa (Figura 5). O teste qui-quadrado mostrou uma diferença altamente significativa na dieta dessa espécie durante a época chuvosa e a seca $\left(X^{2}=112,394 ;\right.$ g.l. $\left.=7 ; p^{* *} \leq 0,000\right)$.

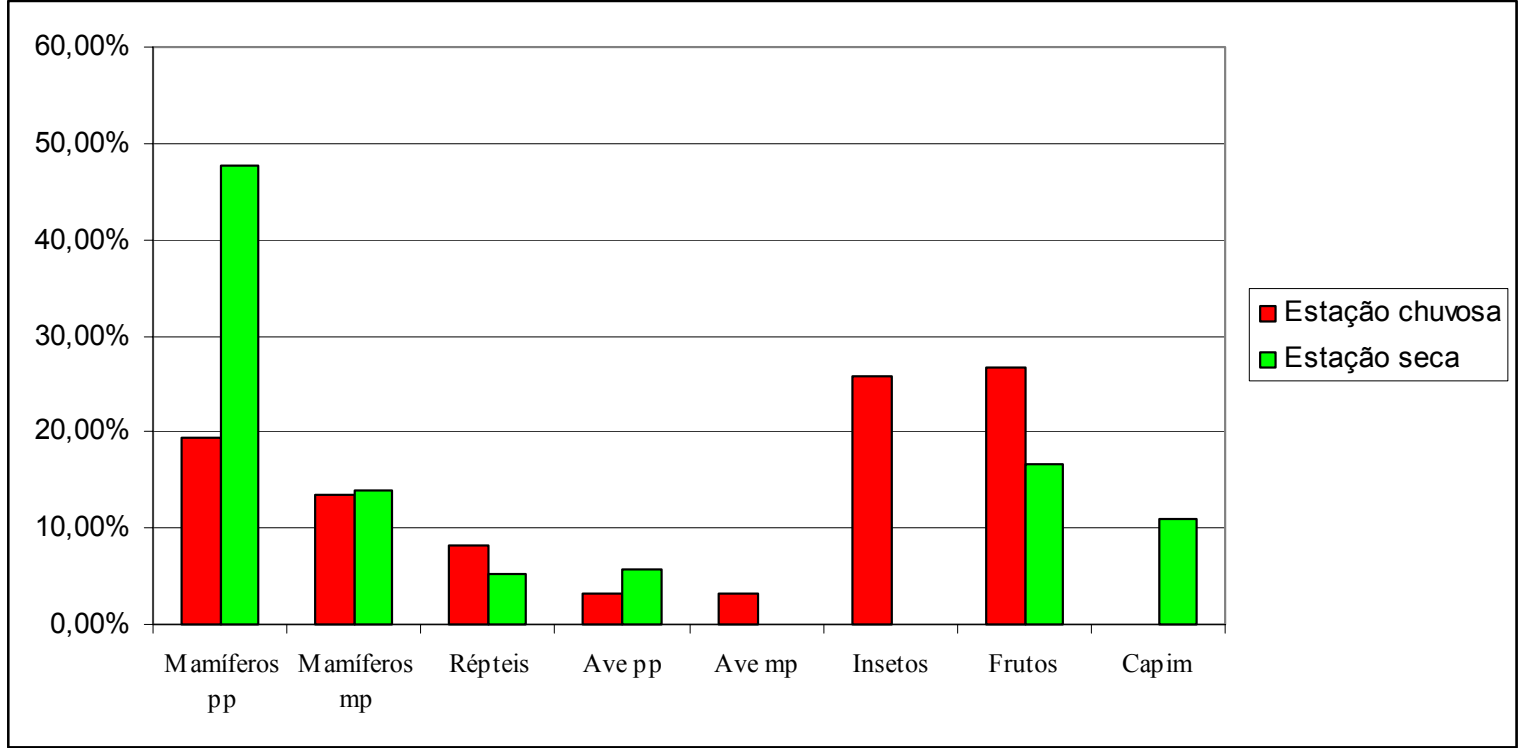

Figura 5. Diferença na dieta do lobo-guará (Chrysocyon brachyurus) nas estações chuvosa (vermelho) e seca (verde), na área de estudo. ( $\mathrm{pp}=$ pequeno porte, $\mathrm{mp}=$ médio porte). 


\subsubsection{Dieta da jaguatirica (Leopardus pardalis)}

Nas fezes de jaguatirica, foram identificados 13 itens, sendo 12 de origem animal e apenas 1 de origem vegetal. Dentre os itens, os tatus do gênero Dasypus foram os mais freqüentes, representando $23,36 \%$ e aparecendo em $84,21 \%$ das fezes, seguidos de roedores de pequeno porte, que representaram $18,98 \%$ dos itens e apareceram em $55,26 \%$ das fezes, e por fim, os marsupiais de pequeno porte $(10,95 \%)$ (tabela 3$)$.

Tabela 3. Porcentagens dos itens encontrados nas fezes $(\mathrm{Oi}=$ quantidade de vezes que $\mathrm{o}$ item aparece em relação a todos os itens) e de fezes com o item encontrado (Ofi = quantidade de vezes que o item aparece em relação ao total de fezes encontradas) para a jaguatirica (Leopardus pardalis), na área de estudo. ( $\mathrm{N}=$ total de fezes; $\mathrm{nfi}=$ número de fezes com o item i; $\mathrm{ni}=$ número de itens $\mathrm{i}$ encontrado nas fezes).

\begin{tabular}{cccccc} 
N=38 & & $\mathbf{n f i}$ & $\mathbf{n i}$ & $\mathbf{O f i}(\%)$ & Oi (\%) \\
Mamíferos de & Marmosops incanus & 4 & 4 & 10,53 & 2,92 \\
pequeno porte & Roedor pp & 21 & 26 & 55,26 & 18,98 \\
& Marsupial pp & 12 & 15 & 31,58 & 10,95 \\
& Mamífero pp & 7 & 7 & 18,42 & 5,11 \\
Mamíferos de & Mamífero mp & 7 & 7 & 18,42 & 5,11 \\
médio porte & Dasypus sp & 32 & 32 & 84,21 & 23,36 \\
& Monodelphis sp & 2 & 2 & 5,26 & 1,46 \\
Répteis & Tamanduá mirim & 8 & 8 & 21,05 & 5,84 \\
& Serpente & 7 & 7 & 18,42 & 5,11 \\
& Tupinambis teguxim & 9 & 9 & 23,68 & 6,57 \\
& Ave mp & 7 & 7 & 18,42 & 5,11 \\
& Ave pp & 9 & 9 & 23,68 & 6,57 \\
& Capim & 4 & 4 & 10,53 & 2,92 \\
& TOTAL & - & 137 & - & 100,00 \\
\hline
\end{tabular}

Na dieta da jaguatirica, verificou-se que só houve consumo de aves de médio porte e capim durante a estação seca, além de um maior consumo de mamíferos de pequeno porte. Somente houve consumo de répteis na fase chuvosa, assim como um maior consumo de aves de pequeno porte e mamíferos de médio porte (Figura 6). 0 teste o qui-quadrado mostrou uma diferença altamente significativa $\left(X^{2}=35,054 ;\right.$ g.l. $\left.=4 ; p^{* *} \leq 0,00\right)$ na dieta da jaguatirica entre os períodos seco e chuvoso. 


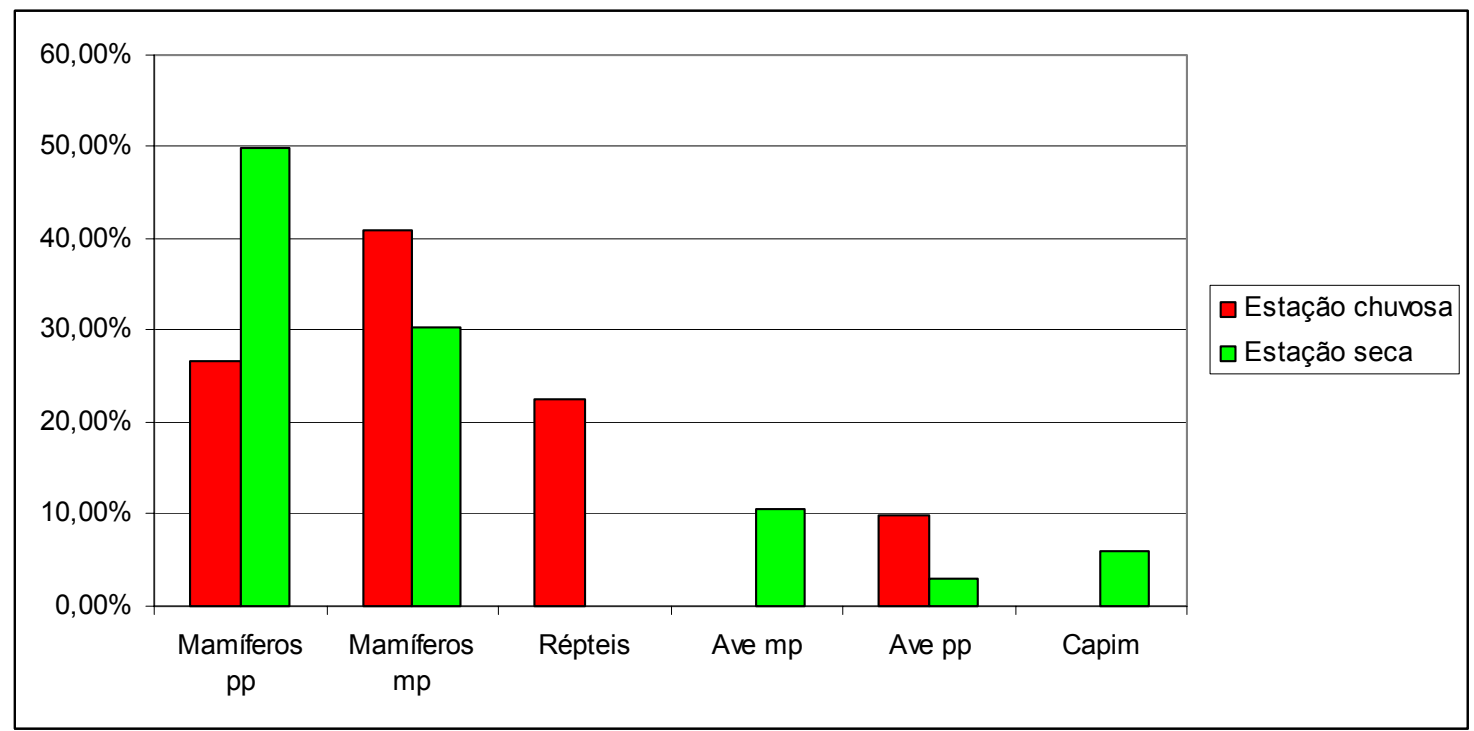

Figura 6. Diferença na dieta da jaguatirica (Leopardus pardalis) nas estações chuvosa (vermelho) e seca (verde) na área de estudo ( $\mathrm{pp}=$ pequeno porte, $\mathrm{mp}=$ médio porte).

\subsubsection{Dieta da onça-parda (Puma concolor)}

Nas fezes de onça-parda, foram identificados nove itens, sendo todos de origem animal. Dentre os itens, os tatus do gênero Dasypus foram os mais freqüentes, representando $47,06 \%$ dos itens e aparecendo em 16,91\% das fezes, seguidos pelo tamanduá-bandeira (Myrmecophaga tridacty/a) que representaram $33,82 \%$ dos itens e apareceram em $16,91 \%$ das fezes, a capivara (Hydrochoerus hydrochaeris) com 32,35\% dos itens e $16,18 \%$ de aparecimento, seguidos pelo teiú (Tupinambis teguxim) com $26,47 \%$ dos itens e $13,24 \%$ das fezes, e por fim, a lebre-européia (Lepus europaeus), espécie de coelho invasor nas terras brasileiras, constituindo 17,65\% dos itens alimentares e aparecendo em $8,82 \%$ das fezes (tabela 4). 
Tabela 4. Porcentagens dos itens encontrados nas fezes (Oi = quantidade de vezes que o item aparece em relação a todos os itens) e de fezes com o item encontrado (Ofi = quantidade de vezes que o item aparece em relação ao total de fezes encontradas) para a onça-parda (Puma concolor), na área de estudo. ( $\mathrm{N}=$ total de fezes; $\mathrm{nfi}=$ número de fezes com o item $\mathrm{i}$; $\mathrm{ni}=$ número de itens i encontrado nas fezes).

\begin{tabular}{|c|c|c|c|c|c|}
\hline $\mathrm{N}=68$ & & nfi & ni & Ofi & Oi \\
\hline \multirow{4}{*}{$\begin{array}{l}\text { Mamíferos de } \\
\text { médio porte }\end{array}$} & Lepus europaeus & 12 & 12 & 17,65 & 8,82 \\
\hline & Dasypus sp. & 32 & 32 & 47,06 & 23,53 \\
\hline & $\begin{array}{l}\text { Tamandua } \\
\text { tetradactyla }\end{array}$ & 8 & 8 & 11,76 & 5,88 \\
\hline & $\begin{array}{c}\text { Myrmecophaga } \\
\text { tridactyla }\end{array}$ & 23 & 23 & 33,82 & 16,91 \\
\hline \multirow{4}{*}{$\begin{array}{l}\text { Mamíferos de } \\
\text { grande porte }\end{array}$} & Mazama guazoubira & 5 & 5 & 7,35 & 3,68 \\
\hline & Tayassu tajacu & 7 & 7 & 10,29 & 5,15 \\
\hline & $\begin{array}{l}\text { Hydrochoerus } \\
\text { hydrochaeris }\end{array}$ & 22 & 22 & 32,33 & 16,18 \\
\hline & Aves mp & 7 & 9 & 10,29 & 6,62 \\
\hline \multirow[t]{2}{*}{ Répteis } & Tupinambis teguxim & 18 & 18 & 26,47 & 13,24 \\
\hline & Total & - & 136 & - & 100,00 \\
\hline
\end{tabular}

Na dieta da onça-parda, verificou-se um aumento no consumo de mamíferos de médio e grande porte (a não ser os tatus do gênero Dasypus) durante a estação chuvosa e um aumento no consumo das aves de médio porte e do teiú (Tupinambis teguxim) na estação seca.

O teste qui-quadrado mostrou que não existe uma diferença estatisticamente significativa $\left(X^{2}=12,496 ; g . I .=8 ; p=0,1304\right)$ na dieta da onça-parda entre os períodos seco e chuvoso.

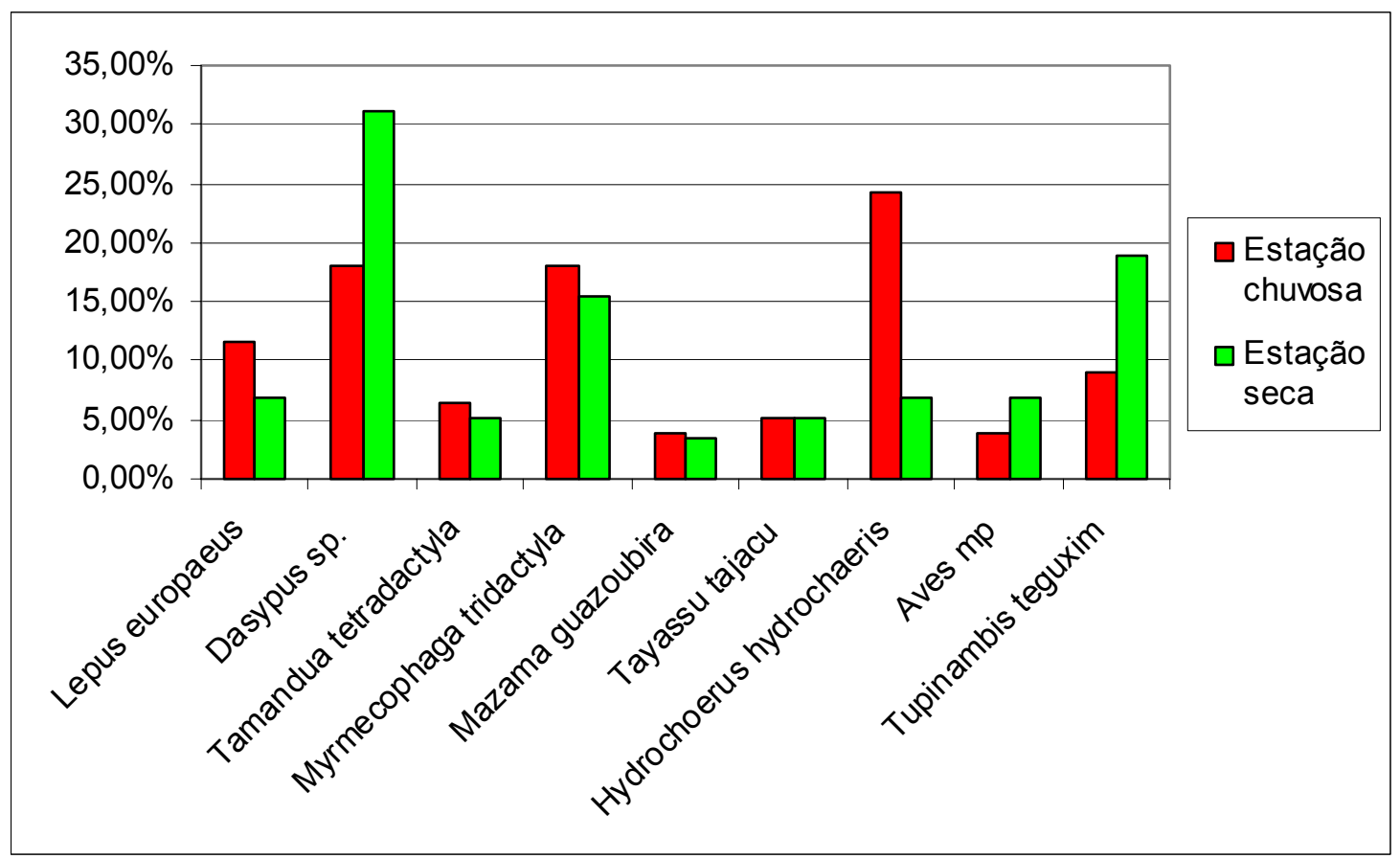

Figura 7. Diferença na dieta da onça-parda (Puma concolor) nas estações chuvosa (vermelho) e seca (verde) na área de estudo $(\mathrm{mp}=$ médio porte). 


\subsubsection{Comparação entre as dietas dos três carnívoros estudados}

\subsubsection{Amplitude de nicho}

Apesar do lobo-guará (Chrysocyon brachyurus) apresentar o maior número de itens utilizado na sua dieta (21), ele obteve a menor largura de nicho $(\mathrm{Ba}=0,399)$. A jaguatirica (Leopardus pardalis), com 13 itens identificados na sua dieta, mostrou uma largura de nicho intermediária entre as três espécies ( $\mathrm{Ba}=0,543)$. A onça-parda (Puma concolor) com 9 itens presentes na sua dieta, apresentou o maior índice de amplitude de nicho $(\mathrm{Ba}=0,723)$.

\subsubsection{Sobreposição de nicho}

O cálculo da sobreposição de nicho entre as espécies mostrou um alto grau de sobreposição entre o lobo-guará e a jaguatirica $(0,765)$, seguido de uma também alta sobreposição entre a onça-parda e a jaguatirica $(0,639)$ e uma baixa sobreposição entre a onçaparda e o lobo-guará $(0,236)$.

\subsubsection{Densidade de fezes nas diferentes áreas}

Foi percorrido um total de $10.115 \mathrm{~km}$ nas estradas de terra existentes na área de estudo durante a procura de fezes. Destes, $4.825 \mathrm{~km}$ foram dentro da área da Estação Ecológica e Experimental de Luís Antonio (EELA), $3.252 \mathrm{~km}$ nas glebas do Parque Estadual do Vassununga e seu entorno próximo $(2 \mathrm{~km})$ e $2.038 \mathrm{~km}$ nas áreas pertencentes a propriedades privadas (PP). Encontramos uma densidade de fezes total de 0,019 fezes/km sendo, as fezes mais abundantes, pertencentes ao lobo-guará $(0,009$ fezes $/ \mathrm{km})$. Quando analisadas separadamente a EELA obteve 0,022 fezes por quilometro percorrido, seguido da área PP com 0,019 fezes $/ \mathrm{km}$ e 0,012 fezes $/ \mathrm{km}$ nas áreas do PEV. As fezes de lobo-guará e de jaguatirica foram mais abundantes na EELA (0,013 e 0,005 fezes/km, respectivamente), as de onça-parda obtiveram os maiores valores de abundância na área PP (0,010 fezes/km) (tabela 5). 
Tabela 5. Número de fezes e densidade de fezes por quilometro percorrido, referentes às três espécies estudadas na área de estudo como um todo e nas três áreas (EELA, PEV e PP) separadamente (n=número de fezes).

\begin{tabular}{ccccc}
\hline & Lobo-guará & Onça-parda & Jaguatirica & Total \\
Total & 93 & 68 & 38 & 199 \\
EELA $(\mathbf{n})$ & 63 & 26 & 27 & 109 \\
PEV $(\mathbf{n})$ & 12 & 20 & 7 & 51 \\
PP $(\mathbf{n})$ & 18 & 22 & 4 & 39 \\
Densidade Total $(\mathbf{n} / \mathbf{k m})$ & 0,009 & 0,006 & 0,003 & 0,019 \\
Densidade EELA $(\mathbf{n} / \mathbf{k m})$ & 0,013 & 0,005 & 0,005 & 0,022 \\
Densidade PEV $(\mathbf{n} / \mathbf{k m})$ & 0,003 & 0,006 & 0,002 & 0,015 \\
Densidade PP $(\mathbf{n} / \mathbf{k m})$ & 0,008 & 0,010 & 0,002 & 0,019 \\
\hline
\end{tabular}

\subsection{Discussão}

Os resultados obtidos na dieta do lobo-guará (Chrysocyon brachyurus) são semelhantes aos obtidos em diversos outros estudos (Dietz 1984, Motta Jr. et al. 1996 e Mantovani 2001). O lobo apresenta-se como uma espécie generalista, alimentando-se de uma variedade grande de itens (desde mamíferos de médio porte até insetos e frutos). A espécie apresentou o menor valor de largura de nicho entre as três espécies estudadas. Isso se deu pelo fato do lobo-guará concentrar sua dieta em poucos tipos de presas: se somarmos as porcentagens dos itens "roedores de pequeno porte" e "lobeira" (Solanum lycocarpum), estes representam praticamente a metade da dieta do lobo. Portanto, apesar de se alimentar de uma enorme variedade de presas, ele tem alta preferência por poucos itens. Sua dieta muda de acordo com a estação chuvosa ou seca, alimentando-se mais dos mamíferos de pequeno porte na estação seca e de frutos na chuvosa.

A jaguatirica (Leopardus pardalis) apresentou uma dieta predominantemente carnívora. $\mathrm{O}$ aparecimento de capim nas fezes não indica que a espécie se alimentou desse item, provavelmente ele foi ingerido de forma ocasional, como é visto em gatos 
domésticos. Não existem muitos trabalhos de análise da dieta da jaguatirica em áreas de cerrado paulista; a maioria dos estudos da dieta desse felino foi realizado em áreas de Floresta Atlântica e Amazônica (Murray \& Gardner 1999, Meza 2002 e Vidolin 2004). As espécies presentes na dieta da jaguatirica, encontradas neste estudo, diferem daquelas encontradas nos estudo citados acima, mas quando agrupamos as espécies em grupos taxonômicos e/ou classes de tamanho os valores aqui encontrados são semelhantes aos encontrados nesses outros estudos.

A jaguatirica apresentou, neste estudo, 13 itens compondo sua dieta, sendo que os tatus do gênero Dasypus foi o gênero mais predado. Não é comum encontrar tatus em freqüências tão altas na dieta de jaguatirica e isso pode indicar uma diminuição das espécies preferencialmente predadas pela jaguatirica, como as aves de médio porte e os roedores (Murray \& Gardner 1999, Meza 2002 e Vidolin 2004), fazendo com que o felino altere sua alimentação para espécies mais abundantes no local, como os tatus. Sua dieta, como no caso do lobo-guará, também se altera com a estação chuvosa ou seca.

A onça-parda (Puma concolor) apresentou uma dieta estritamente carnívora, tendo sido encontrados 9 tipos de itens, todos de origem animal. Mostrou certa preferência pelos tatus, corroborando um estudo de Mantovani (2001), na mesma área, mas isso pode indicar, como no caso da jaguatirica, uma adaptação alimentar voltada para as espécies mais abundantes na área.

Um ponto importante na dieta da onça-parda foi a presença de lebre-européia (Lepus europaeus). Nenhum estudo realizado na região tinha apontado a presença dessa espécie na área. A presença na dieta da onça mostra ainda mais o caráter oportunista da onça-parda, que se alimenta do que estiver mais disponível no ambiente. Por outro lado, a presença da lebre na dieta da onça é preocupante, pois se apareceram em altas freqüências na dieta, muito possivelmente apresentam altas freqüências na região de estudo. 
Apesar da onça-parda se alimentar de menos itens que o lobo-guará e a jaguatirica, as freqüências de utilização dos itens são mais homogêneas, mostrando menor preferência alimentar e, conseqüentemente, uma maior largura de nicho. Não foi encontrada diferença significativa na dieta da onça durante os períodos seco e chuvoso.

O alto grau de sobreposição de nicho entre a jaguatirica e o lobo-guará pode indicar um aumento na competição entre essas duas espécies que são de tamanho e peso parecidos. Existem indícios de competição direta entre essas espécies, com pelos de jaguatirica sendo encontrados nas fezes de lobo-guará (observação pessoal). A sobreposição de nicho entre onça-parda e a jaguatirica $(0,639)$ já era esperada, pois as espécies são de grupos taxonômicos bem próximos. Já a baixa sobreposição entre lobo e onça indica que ainda existem na área espécies de médio e grande porte dos quais a onçaparda prefere se alimentar.

A análise das densidades de fezes, de lobo-guará, onça-parda e jaguatirica na área como um todo e nas três subáreas - Estação Ecológica e Experimental de Luiz Antonio (EELA), Parque Estadual de Vassununga (PEV) e nas propriedades privadas (PP) mostraram diferenças importantes entre as espécies e as áreas. A EELA foi a área que obteve os maiores valores de abundância para a jaguatirica e o lobo-guará, isso pode ser explicado pelo fato de ser a área com o maior fragmento de vegetação nativa, conseqüentemente, com maior capacidade de suporte e mais presas e habitats disponíveis para os predadores. As fezes de onça-parda foram mais encontradas na área PP, corroborando a afirmação de que a onça-parda entre as três espécies estudadas é a menos sensível às alterações antrópicas, entre as três espécies estudadas, podendo utilizar as áreas alteradas tão bem quanto as naturais. Os dados obtidos aqui foram muito semelhantes aos encontrados por Mantovani (2001) em estudo realizado na mesma área. 


\subsection{Bibliografia}

Audubon JJ, Bachman J 1846. The Viviparous Quadrupeds of North America. Volume 2. John J. Audubon, New York.

BEGON, M., TOWNSEND, C.R. \& HARPER, J.L. 2006. Ecology: From individuals to ecosystems. 4 ed. Blackwell Scientific Publications, Oxford.

BEIER, P. 1995. Dispersal of juvenile cougars in fragmented habitat. Journal of Wildlife Management 59: 228237.

BÉLISLE, M. 2005. Measuring landscape connectivity: the challenge of behavioral landscape ecology, Ecology 86:1988-1995.

BISBAL, F.J. \& J. OJASTI. 1980. Nicho trofico del zorro Cerdocyon thous (Mammalia, Carnivora). Acta Biologica Venezuelica, Caracas, 10 (4): 469-496.

BRADY, C. A. 1979. Observations on the behavior and ecology of the crab-eating fox (Cerdocyon thous). Pp. 161-171 in Vertebrate ecology in the northern Neotropics (J. F. Eisenberg, ed.). Smithsonian Institution Press, Washington, D.C.

CHINCHILLA, F. A. 1997. La dieta del jaguar (Panthera onca), el puma (Felis concolor) y el manigordo (Felis pardalis) (Carnivora: Felidae) en el Parque Nacional Corcovado, Costa Rica. Rev. Biol. Trop. 45(3): 1223-1229.

CONSERVAÇÃO INTERNACIONAL 2002. The new hotspots. Conservation International, Washington, D.C. Disponível em: http://www.conservation.org (ultimo acesso em dezembro de 2007).

CRAWSHAW, P.G. \& H.B. QUIGLEY 1984. A ecologia do jaguar ou onça-pintada no pantanal.

Estudos Bioecológicos do Pantanal, relatório final - parte 1 .Instituto Brasileiro de Desenvolvimento Florestal (IBDF), 112p.

DIETZ, J.M. 1984. Ecology and social organization of the maned wolf (Chrysocyon brachyurus).

Smithsonian Contributions to Zoology 392:1-51.

DOWNES, K.A. Handasyde \& Elgar, M. A. 1997. The use of corridors by mammals in fragmented Australian eucalypt forests. Conservation Biololgy. 11(3):718-726. 
FACURE, K.G. \& E.L.A. MONTEIRO-FILHO. 1996. Feeding habits of the Crab-eating fox, Cerdocyon thous (Carnivora, Canidae), in a suburban area of southeastern Brazil. Mammalia, Paris, 60 (1): $147-149$.

GARLA, R. C.; SETZ E. Z. F. 2001. Jaguar (Panthera onca) food habits in Atlantic Rain Forest of southeastern Brazil. Biotropica 33(4): 691-696.

GODWIN, B. J. \& FAHRIG L. 2002. How does landscape structure influence landscape connectivity? Oikos 99:552-570.

KORMAN, V. Proposta de interligação das glebas do Parque Estadual de Vassununga (Santa Rita do Passa Quatro, SP). Tese. (Mestrado em Ecologia de Agroecossistemas) Universidade de São Paulo - Escola Superior de Agricultura. 2003.

LOCKIE, J. D. 2002. The estimation of the food of foxes. 1959. Appud JUAREZ, K. M. \& MARINHOFILHO, J. Diet, habitat use, and home range of sympatric canids in central Brazil. Journal of Mammalogy 83 (4): 925-933.

MANTOVANI, J.E. 2001. Telemetria convencional e via satélite na determinação da área de vida de três espécies de carnívoros da região nordeste do estado de São Paulo. Tese de doutorado. Universidade de São Carlos. São Carlos, SP.

METZGER, J.P. 2001. Effects of deforestation pattern and private nature reserves on the forest conservation in agricultural areas of the Brazilian Amazon. Biota Neotropica 1(1/2) Disponível em: http://www.biotaneotropica.org.br/v1n12.

MEZA A. D. V., E. M. Meyer, \& C. A. L. González. 2002. Ocelot (Leopardus pardalis) food habits in a tropical deciduous forest of Jalisco, Mexico. American Midland Naturalist. 148:146-154

MOTTA-JUNIOR, J. C.; TALAMONI, S. A. 1996. LOMBARDI J. A.; SIMOKOMAKI K. Diet of maned wolf, Chrysocyon brachyurus, in central Brazil. Journal of Zoology 240: 277-284.

MURRAY JL, GARDNER GL. 1997. Leopardus pardalis. Mammalian Species 548:1 - 10

NIMER, E. 1977. Climatologia do Brasil. Rio de Janeiro: IBGE.

JÁCOMO, A. T. A. 1999. Nicho alimentar do lobo-guará (Chrysocyon brachyurus Illiger, 1811) no Parque Nacional das Emas - Go. Dissertação (Mestrado), Universidade Federal de Goiás, Goiania, Brasil. 104 pp. 
JAKSIC, F. M.; FEINSINGER, P.; JIMÉNEZ J. E. 1993. A long-term study on the dynamics of guild structure among predatory vertebrates at a semi-arid Neotropical site. Oikos. 67: 87-96.

OLIVEIRA, T.G., CASSARO, K. 1999. Guia de identificação dos felinos brasileiros. São Paulo, Sociedade de Zoológicos Brasileiros, $2^{\mathrm{a}}$ ed., 60p.

PAVEZ, E. R.; GONZÁLEZ, C. A.; JIMÉNEZ, J. E. 1992. Diet shifts of Black-chested Eagles (Geranoaetus melanoleucus) from native prey to European rabbits. Journal Raptor Res. 26: $27-32$.

PIANKA, E. R. 1974. Niche overlap and diffuse competition. Proc. Nat. Acad. Sci. 5: 2141-2145.

PIRES, J. S. R. 1995. Análise ambiental voltada ao planejamento e gerenciamento do ambiente rural: abordagem metodológica aplicada ao município de Luiz Antônio - SP. Tese (Doutorado em Ecologia) UFScar - Departamento de Hidrobiologia - Laboratório de Análises e Planejamento Ambiental - São Carlos.

PUTMAN, R. J. 1984. Facts from feaces. Mammal Review 14(2): 79-97.

QUADROS, J. 2002. Identificação microscópica de pêlos de mamíferos brasileiros e sua aplicação no estudo da dieta de carnívoros. Tese. (Doutorado em Ecologia) Universidade Federal do Paraná - Setor de Ciências Biológicas.

REYNOLDS, J.C. \& AEBISCHER, N.J. 1991. Comparison and quantification of carnivore diet by faecal analysis: a critique, with recommendations, based on a study of the Fox Vulpes vulpes. Mammal Review, 21, 97-122.

ROPER, T. J., 1994. The European badger Meles meles: food specialist or generalist? Journal of Zoology, London. 234:437-452.

SANTOS, E. F. 1999. Ecologia Alimentar e Dispersão de Sementes pelo Lobo-Guará (Chrysocyon brachyurus, Illiger, 1811) em uma Área Rural No Sudeste do Brasil ( Carnivora: Canidae). Dissertação (Mestrado). UNESP, Rio Claro. 68 p.

SERVÍN, J. \& HUXLEY, C. 1991. La dieta del coyote en un bosque de encino-pino de la Sierra Madre Occidental de Durango, México. Acta Zool. Mexicana 44: 1-26.

TOPPA, R. H. 2004 Estruturas e diversidade florística das diferentes fisionomias de Cerrado e suas correlações com o solo na Estação Ecológica de Jataí, Luiz 
Antônio, SP. Tese. (Doutorado em Ecologia e Recursos Naturais). Universidade Federal de São Carlos - Centro de Ciências Biológicas e da Saúde. São Carlos, SP.

TURNER, M.G. 2005. Landscape ecology in North America: past, present and future. Ecology 86:1967-74.

VALKENBURGH, B. V. \& WAYNE, R. K. 1994. Shape divergence associated with size convergence in sympatric east Africans jackals. Ecology 75(6): 1567-1581.Gittleman, J.L. 1985. Carnivore body size: ecological and taxonomic correlates. Oecologia 67:540-554.

WILSON, E.O. (1993) The Diversity of Life. Harvard: Harvard University Press.

WILSON, G.J. \& DELAHAY, R. J. 2001. A review of methods to estimate the abundance of terrestrial carnivores using signs and observation. Wildlife Research 28: 151-164.

WRIGHT, S. J., GOMPPER, M., DELEON, B. 1994. Are large predators keystone species in Neotropical forest? The evidence from Barro Colorado Island. Oikos 71: 279-294. 


\section{Conclusões Gerais:}

O uso das armadilhas fotográficas, na coleta de registros de mamíferos de médio e grande porte, foi considerado muito satisfatório. Foram obtidos diversos registros de diferentes espécies que se sabia existir na região. Algumas espécies que sabidamente existem na região e não foram a amostradas, são aquelas que possuem características específicas que não foram objeto da amostragem (por exemplo: espécies com hábitos arborícolas e/ou habitats muito específicos).

As fitofisionomias de cerrado foram as que apresentaram maior riqueza específica e maiores valores de freqüência de uso pelas espécies de mamíferos amostradas. Isso ocorreu principalmente pelo fato dos fragmentos de cerrado amostrados serem de a melhor qualidade estrutural na paisagem (tamanho, grau de isolamento) e sofrerem menos com a pressão antrópica que os fragmentos de floresta semidecídua.

Nas áreas de plantio de eucaliptos foram registradas espécies que necessitam de grandes áreas para sobreviver: veado-catingueiro (Mazama guazoubira), onça-parda (Puma concolor), jaguatirica (Leopardus pardalis), gato-mourisco (Puma yagouaroundl) e lobo-guará (Chrysocyon brachyurus). Isso mostra que essas áreas, podem ser permeáveis (transpostas) a algumas espécies de mamíferos, principalmente as cursoriais. Para diminuir a probabilidade de um indivíduo morrer ao cruzar estas matrizes (por caça, atropelamento, ingestão de embalagens e produtos químicos e outras pressões antrópicas) devemos pensar em formas de manejo das áreas que seja menos impactantes para as espécies, como por exemplo, o corte intercalado de talhões de eucalipto (de modo a não deixar áreas muito grandes sem cobertura vegetal), a maior fiscalização das áreas, a manutenção do sub-bosque.

A maioria das espécies de mamíferos de médio e grande porte amostrada foi mais freqüentemente fotografada no período noturno, confirmando o comportamento criptico da maioria dos mamíferos de médio e grande porte. Mas outros períodos, principalmente o diurno, também foram bastante utilizados, mostrando um caráter mais generalista na preferência por períodos de atividade, principalmente pelo quati (Nasua nasua), irara (Eira barbara), jaguatirica (Leopardus pardalis) e veado-catingueiro (M.guazoubira). 
Dos fragmentos estudados, o que mostrou maior qualidade, tanto estrutural (índices de paisagem) como qualidade ambiental (aqui refletida pelas maiores freqüências dos mamíferos amostrados e a maior riqueza de mamíferos de médio e grande porte), foi a Estação Ecológica de Jataí (EEJ). Os resultados indicam esse fragmento como a grande área-fonte da paisagem. Outro fragmento que tem características de área-fonte é a gleba Cerrado Pé-de-Gigante (PG), que também registrou altas freqüências de mamíferos de médio e grande porte e possui melhores características estruturais que outros dos fragmentos amostrados.

Os altos valores de correlação entre as freqüências de mamíferos nos diferentes fragmentos e os índices da paisagem mostram que, cada vez mais, variáveis estruturais da paisagem (por exemplo: área do fragmento, relação perímetro/área - que reflete a pressão do efeito de borda no fragmento -, índices que levem em conta o grau de isolamento e a quantidade de habitat disponível próximo ao fragmento e tipos de matrizes que influenciam diretamente o fragmento), são importantes na persistência das espécies da paisagem. Esses índices, portanto, devem ser utilizados em modelos de distribuição de espécies como variáveis preditoras.

A análise da dieta do lobo-guará ( $C$. brachyurus), da jaguatirica (L. pardalis) e da onçaparda ( $P$. concolor) por meio da coleta e triagem de fezes encontradas nas estradas de terra e aceiros presentes na área de estudo foi um método satisfatório para analisar os nichos das espécies estudadas. O numero de fezes coletadas e triadas foi sufuiciente para realizar as análises estatísticas e para cálculos de densidade de fezes por quilometro percorrido, tendo sido encontrados resultados muito semelhantes ao de outros estudos.- dizer resumidamente quais !

$\mathrm{O}$ alto valor de largura de nicho $(\mathrm{Ba}=0,723$ ) encontrado para onça-parda mostra um caráter generalista desta espécie, corroborando os dados do primeiro capítulo desta dissertação, que também apontam para um comportamento generalista desta espécie na preferência por habitas e períodos de atividade Entre jaguatirica e a onça-parda $(0,639)$, era esperado um alto grau de sobreposição de nicho, pois são espécies muito próximas taxonomicamente. Entretanto, o alto valor encontrado na sobreposição entre jaguatirica e lobo-guará $(0,765)$ é preocupante, pois não existem estudos apontando uma alta competição indireta (disputa por recursos) para estas duas espécies. Os valores obtidos para o uso de habitat conforme períodos de atividade também 
são muito parecidos entre essas duas espécies, indicando que, além de uma competição indireta por recursos alimentares, pode existir uma competição direta por território.

A alta densidade de fezes por quilometro, dentro da Estação Ecológica de Jataí (EEJ), dá um peso ainda maior à hipótese de que a área é uma área-fonte de indivíduos na paisagem. A única espécie que não obteve a maior densidade de fezes na EEJ foi a onça-parda que obteve a maior densidade nas propriedades privadas (PP), mostrando novamente seu caráter generalista.

O fato de as PP terem obtido valores maiores de densidade de fezes que o Cerrado Pé-deGigante (PG) pode indicar que, juntos, os fragmentos existentes nas áreas privadas podem apresentar uma capacidade de suporte maior que o fragmento PG, para estas espécies de carnívoros estudadas.

Conclui-se que o estudo de áreas fragmentadas (protegidas e não protegidas pelo Estado), de seus entornos e de características das diferentes matrizes presentes nas paisagens agroflorestais é essencial para a manutenção da biodiversidade nessas áreas. Não se pode imaginar ou almejar que áreas fragmentadas voltem a ser contínuas estruturalmente, mas, estudando as relações entre o comportamento das espécies-alvo e as características estruturais da paisagem e os diferentes tipos de matrizes, pode-se estabelecer estratégias de manejo que visem o incremento da conectividade funcional da paisagem e a diminuição da probabilidade de morte de indivíduos que estiverem cruzando áreas não naturais que envolvem ás áreas naturais.

Este trabalho mostrou a importância dos pequenos fragmentos presentes em propriedades particulares para a conservação da biodiversidade, promovendo a percolação da fauna na paisagem. Sem o incentivo a criação Reservas Particulares do Patrimônio Natural (RPPNs), que inclui a participação do produtor rural no processo de manejo das paisagens, o objetivo da conservação da biodiversidade dificilmente será alcançado, principalmente pelo fato de que, sem essas áreas, as unidades de conservação estabelecidas no Estado ficam isoladas, levando a maior parte das populações à exitinção. 